\begin{abstract}
UNIVERSIDADE DE SÃO PAULO
FACULDADE DE MEDICINA DE RIBEIRÃO PRETO

DEPARTAMENTO DE BIOQUÍMICA E IMUNOLOGIA

PROGRAMA DE PÓS-GRADUAÇÃO EM BIOQUÍMICA
\end{abstract}

Camila Pederiva Rossignoli

Efeitos da suplementação da dieta com ácido linoleico conjugado (CLA) e óleo de peixe isolados ou em conjunto sobre o metabolismo energético mitocondrial, celular e corporal

Ribeirão Preto - SP

2016 
Camila Pederiva Rossignoli

Efeitos da suplementação da dieta com ácido linoleico conjugado (CLA) e óleo de peixe isolados ou em conjunto sobre o metabolismo energético mitocondrial, celular e corporal

Dissertação apresentada ao programa de PósGraduação em Bioquímica da Faculdade de Medicina de Ribeirão Preto, Universidade de São Paulo, como parte das exigências para obtenção do título de Mestre em Bioquímica. Área de Concentração: Bioquímica.

Orientadora: Dra. Luciane Carla Alberici

Ribeirão Preto - SP

2016 
Autorizo a reprodução e divulgação total ou parcial deste trabalho, por qualquer meio convencional ou eletrônico, para fins de estudo e pesquisa, desde que citada a fonte.

\section{Efeitos da suplementação da dieta com ácido linoleico conjugado (CLA) e óleo de peixe isolados ou em conjunto sobre o metabolismo energético mitocondrial, celular e corporal}

\section{ROSSIGNOLI, Camila Pederiva}

Efeitos da suplementação da dieta com ácido linoleico conjugado (CLA) e óleo de peixe isolados ou em conjunto sobre o metabolismo energético mitocondrial, celular e corporal. Ribeirão Preto, 2016.

$89 \mathrm{p}$.

Dissertação de Mestrado, apresentada à Faculdade de Medicina de Ribeirão Preto/USP. Área de concentração: Bioquímica.

Orientadora: Dra. Luciane Carla Alberici.

1. Mitocôndria. 2. Óleo de peixe. 3. Ácido linoleico conjugado.

4. Desacoplamento. 5. Biogênese 


\section{FOLHA DE APROVAÇÃO}

Nome: ROSSIGNOLI, Camila Pederiva

Título: Efeitos da suplementação da dieta com ácido linoleico conjugado (CLA) e óleo de peixe isolados ou em conjunto sobre o metabolismo energético mitocondrial, celular e corporal.

Dissertação apresentada ao programa de PósGraduação em Bioquímica da Faculdade de Medicina de Ribeirão Preto, Universidade de São Paulo, como parte das exigências para obtenção do título de Mestre em Bioquímica. Área de Concentração: Bioquímica.

Aprovado em de de

\section{BANCA EXAMINADORA}

Prof. Dr.

Instituição: Assinatura:

Prof. Dr.

Instituição: Assinatura:

Prof. Dr.

Instituição: Assinatura: 


\section{AGRADECIMENTOS}

Em primeiro lugar agradeço a Deus criador de todas as coisas e concessor da sabedoria.

Aos meus pais, Djalma e Mônica, e ao meu irmão Rafael, agradeço pelo apoio, amor e educação que me deram. Por me ensinarem o valor de todas as coisas e a importância da perseverança. Obrigada por compreenderem minha ausência em casa.

À minha orientadora $\operatorname{Prof}^{a}$. Dr ${ }^{a}$. Luciane pela orientação, atenção e amizade. Aos ensinamentos e principalmente por ter depositado em mim confiança para execução deste trabalho. Também pelos instantes de descontração no laboratório e pelas experiências compartilhadas. A Prof ${ }^{a}$. Dr ${ }^{\mathrm{a}}$. Carem pelos conselhos (e broncas) que foram primordiais para a aprovação na qualificação.

Ao meu namorado Marco, pelo imenso apoio, amor, calma e paciência infinita. Sempre me auxiliando (na saúde e na doença), ensinando coisas novas e truques no Excel. A sua excelente companhia nos incontáveis cafés, almoços, jantares e passeios. Pelas músicas que tocou e cantou comigo e por me proporcionar numerosas alegrias. Pelos conselhos que sempre me traz calma e paz. Obrigada por se tornar parte da minha vida e estar ao meu lado em todos os momentos.

Às amigas da casa 6, Mariana, Fernanda e Gisele, pela convivência diária, companheirismo, assistência e principalmente por serem exemplos inspiradores de profissionais. Ao Clube da Luluzinha, o qual faziam parte também Renata, Luiza e Sarinha, pelas noites de fondue e madrugadas com discussões de assuntos altamente científicos e filosóficos que terminava em cantoria.

Ao pessoal da Vila, Brenda, Júlia, Guga, Luana, Peagá, Lino, Xaxá, Gabriel e Chico que contribuíram incrivelmente para o meu crescimento pessoal. Pela energia boa, as melhores festas e churrascos que já participei e sobretudo pela amizade.

Aos amigos de laboratório, Bruno, Anderson, Flávia, Felipe, Tati, Zuccolotto, Amanda, André, Igor, Jony, Tanes e Lucas pelas ideias e conhecimentos trocados nos vários cafés na copinha, pela amizade e por tornarem extremamente agradável o ambiente de trabalho. Obrigada acolhimento e carinho que me receberam no laboratório. Aos técnicos Ieda, Lu, Alcides e Naná pela colaboração e assistência.

Aos professores do departamento pelo conhecimento transmitido e a Ivone pela eficiência e ajuda nos assuntos burocráticos.

Aos que não citei, mas não menos importantes também agradeço por estarem presentes e contribuírem nesta trajetória. A FAPESP, FAEPA e a CAPES pelo auxílio financeiro. 


\section{RESUMO}

ROSSIGNOLI, C. P.; Efeitos da suplementação da dieta com ácido linoleico conjugado (CLA) e óleo de peixe isolados ou em conjunto sobre o metabolismo energético mitocondrial, celular e corporal. 2016. 89f. Dissertação (Mestrado) - Faculdade de Medicina, Universidade de São Paulo, Ribeirão Preto, 2016.

Atualmente no Brasil mais da metade da população adulta tem excesso de peso e $21 \%$ estão obesos. A obesidade é uma doença que se encontra em evidente crescimento, sendo considerada a epidemia do século XXI. Como alternativa de tratamento e prevenção, o uso de ácidos graxos que possuem habilidade de induzir a expressão de genes com importante papel em modulações metabólicas e mitocondriais têm sido estudados. $\mathrm{O}$ ácido linoleico conjugado (CLA, 18:2) é da família ômega-6, descrito por sua propriedade antiobesidade relacionada à diminuição da adiposidade e ao aumento do metabolismo corporal. O óleo de peixe (OP) é uma mistura de ácidos graxos poli-insaturados eicosapentaenóico (EPA, 20:5) e docosahexaenóico (DHA, 22:6) da família ômega-3, conhecido por aumentar a sensibilidade à insulina, o colesterol-HDL, pelas suas propriedades antiinflamatórias e sua ação protetora sobre o sistema nervoso. O objetivo deste estudo foi verificar os efeitos da suplementação da dieta de camundongos C57BL6 com CLA em conjunto com OP durante 60 dias sobre aspectos bioquímicos, moleculares e fisiológicos do metabolismo mitocondrial e corporal. Verificamos que a suplementação da dieta com CLA e OP in vivo: aumenta o metabolismo corporal, efeito atribuído à ambos os óleos; prejudica o metabolismo da glicose circulante, proporcionado exclusivamente pelo CLA; reduz o nível de movimentação, proporcionado exclusivamente pelo OP. No fígado: aumenta a expressão de UCP2, a atividade de proteínas desacopladoras e a $\beta$ oxidação, efeito atribuído à ambos os óleos; aumenta o número de mitocôndrias, proporcionado exclusivamente pelo OP. CLA aumenta a produção de espécies reativas de $\mathrm{O}_{2}$ (EROs) a qual é revertida pelo OP em conjunto. No músculo sóleo: aumenta a biogênese mitocondrial via PGC$1 \alpha$ e a expressão de UCP2, proporcionados pelo OP. Por fim, no hipocampo: aumenta o número de mitocôndrias, estimulo dado por ambos os óleos; aumenta a atividade desacopladora e reduz a produção de EROs, proporcionados exclusivamente pelo CLA. Concluímos que na suplementação conjunta os efeitos do OP são predominantes nos metabolismos corporal, hepático e muscular, e na movimentação corporal, enquanto que o efeito predominante do CLA é a diminuição na sensibilidade à insulina. Já no cérebro, o OP potencializa os efeitos do CLA. Palavras-chave: Mitocôndria, óleo de peixe, ácido linoleico conjugado, desacoplamento e biogênese 


\begin{abstract}
ROSSIGNOLI, C. P.; Effects of dietary supplementation with conjugated linoleic acid (CLA) and fish oil either alone or in combination on mitochondrial, cellular and body energy metabolism 2016. 89f. Dissertação (Mestrado) - Faculdade de Medicina, Universidade de São Paulo, Ribeirão Preto, 2016.
\end{abstract}

Currently in Brazil more than a half of adult population has overweight, and $21 \%$ are obese. This evident growing disease is considered the 21th century's epidemy. Some fatty acids have been considered an alternative treatment and prevention strategy for obesity due to their ability to stimulate gene expression with important role in cellular and mitochondrial metabolisms. Conjugated linoleic acid (CLA, 18:2) from omega-6 family, with anti-obesity properties related to diminution of adiposity and increments in body metabolism. The fish oil (FO) is a mixture of the poli-unsaturated fatty acids eicosapentaenoic (EPA, 20:5) and docosahexaenoic (DHA, 22:6) from omega-3 family, known for improving insulin sensibility and HDL-cholesterol, anti-inflammatory properties and protective action over the central nervous system. The objective of this study was to examine the effects of dietary supplementation of CLA in conjunction with FO during 60 days over biochemical, molecular and physiological aspects of mitochondrial and body metabolism in C57BL6 mice. Diet supplementation with CLA and FO in vivo: raise body metabolism, an effect attributed to both oils; affect glucose metabolism, exclusively proportionate by CLA; diminish the level of mice movement, exclusively proportionate by FO. In liver: increase UCP2 expression, uncoupling proteins activity and $\beta$-oxidation, stimulated by both oils; increase mitochondrial density, exclusively proportionate by FO. CLA also raises the reactive oxygen species (ROS) production, which is reversed by FO in conjunction. In soleus muscle: increase mitochondrial biogenesis through PGC-1 $\alpha$ and the UCP2 expression, exclusively proportionate by FO. Lastly, in hippocampus: increase mitochondrial density, stimulated by both oils; stimulate uncoupling activity and diminish ROS production, exclusively proportionate by CLA. In conclusion, in the dietary supplementation with CLA and FO in conjunction the FO effects are prevalent in metabolisms of body, liver and muscle, and in body movement, while the CLA effects are prevalent in decreasing insulin sensitivity. However in the brain, the FO potentiates the effects of CLA.

Keywords: Mitochondria, fish oil, conjugated linoleic acid, uncoupling, biogenesis 


\section{LISTA DE FIGURAS}

Figura 1: Estrutura morfológica da mitocôndria. As setas mostram a membrana externa, a membrana interna, a matriz mitocondrial, os ribossomos, o espaço intermembranas, as cristas mitocondriais, o DNA mitocondrial (mtDNA) e a ATP sintase presente na membrana interna que é responsável pela síntese de ATP (Figura retirada e modificada de KARP, 2013)..........3

Figura 2: Modelo quimiosmótico proposto por Petter Mitchell em 1961. Elétrons do NADH e de substratos oxidáveis passam pelos complexos da cadeia transportadora de elétrons (CTE) localizados na membrana mitocondrial interna. O fluxo de elétrons é acompanhado pelo bombeamento de prótons produzindo um gradiente eletroquímico. A membrana é impermeável a prótons, por isso eles retornam a matriz mitocondrial por canais específicos como a ATPsintase. Essa força próton-motriz impulsiona a síntese de ATP (Figura retirada de NELSON; COX, 2011).

Figura 3: Produção de calor através do desacoplamento causado pela proteína desacopladora (UCP). As UCPs fornecem uma via alternativa para a reentrada de prótons na matriz e a energia é dissipada na forma de calor (Figura retirada de NELSON; COX, 2014).

Figura 4: Esquemas dos mecanismos de desacoplamento das UCPs utilizando ácidos graxos livres como substrato. (A) Mecanismo proposto por GARLID et al., 1996. (B) Mecanismo proposto por Winkler e Klingenberg (Figura retirada e modificada de KRAUSS; ZHANG; LOWELL, 2005)

Figura 5: Ciclo de vida da mitocôndria. Durante o seu ciclo de vida, as mitocôndrias se fundem umas com as outras (fusão mitocondrial) e se separaram novamente (fissão mitocondrial) e as organelas danificadas são descartadas através da mitofagia. (Figura retirada e modificada de WESTERMANN, 2010). 11

Figura 6: PGC-1 $\alpha$ atua como coativador de fatores de transcrição que desencadeiam processos mitocondriais (Figura retirada e modificada de KELLY; SCARPULLA, 2004).

Figura 7: Formação de EROs nas mitocôndrias e sistema de defesa mitocondrial. Quando a taxa de entrada e a de transferência de elétrons na cadeia não são coordenadas, a produção do radical superóxido aumenta nos complexos I e III à medida que o radical ubiquinona parcialmente reduzido doa um elétron para o $\mathrm{O}_{2}{ }^{0^{-}}$. A enzima aconitase leva a formação do radical hidroxil $\left({ }^{\circ} \mathrm{OH}\right)$, fortemente reativo. A glutationa reduzida $(\mathrm{GSH})$ doa elétrons para a redução de $\mathrm{H}_{2} \mathrm{O}_{2}$ e dos resíduos oxidados de cisteína de enzimas e de outras proteínas. O GSH é regenerado a partir da forma oxidada (GSSG) por redução utilizando NADPH (Figura retirada de NELSON; COX, 2011).

Figura 8: Estruturas químicas planares do (A) ácido linoleico (C18:2 c-9,c-12) e seus isômeros geométricos e posicionais. (B) CLA C:18 c-9, t-11 e (C) CLA C:18 c-10, c-12.

Figura 9: Estruturas químicas planares dos ácidos graxos $\omega-3$ mais importantes. (A) ácido $\alpha$ linolênico (C18:3), (B) Ácido eicosapentanóico (EPA, C20:5) e (C) Ácido docosahexanóico (C22:6).

Figura 10: Divisão dos animais em grupos experimentais: Controle, CLA, óleo de Peixe (OP) e CLA + óleo de peixe (CLA + OP).... 
Figura 11: Esquemas mostrando a (A) detecção da movimentação horizontal e (B) detecção da

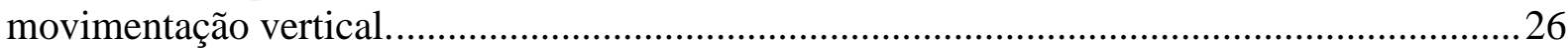

Figura 12: Representação esquemática do processo de isolamento de mitocôndrias pelo método de centrifugação diferencial.

Figura 13: Sequência das adições dos compostos durante o ensaio para a determinação do consumo de oxigênio nas mitocôndrias isoladas. Em (A) o ensaio na ausência de LA e em (B) na presença de LA.

Figura 14: Sequência das adições dos compostos durante o ensaio para a determinação da $\beta$ oxidação nas mitocôndrias isoladas.

Figura 15: Conversão de Amplex Red em Resorufina. A HRP usa o Amplex Red como doador de elétrons durante a redução de peroxido de hidrogênio em água. O composto resultante é a resorufina, um composto que emite fluorescência em comprimentos de onda de excitação e emissão de $563 \mathrm{~nm}$ e $587 \mathrm{~nm}$, respectivamente.

Figura 16: A Figura mostra o momento da injeção da mitocôndria e o monitoramento de EROs durante 10 minutos (600 segundos).

Figura 17: Sequência das adições dos compostos durante o ensaio para a determinação do consumo de oxigênio nos tecidos permeabilizados.

Figura 18: (A) Curva de monitoramento semanal do peso corporal de camundongos suplementados com CLA e OP sozinhos ou em conjunto e controles em função do período de tratamento. (B) Gráfico mostrando a média do ganho de peso final de cada grupo. Média \pm EPM. $n=5-6 . P<0,05$.

Figura 19: Monitoramento durante 24 horas do (A e B) volume de oxigênio consumido (VO2), (C e D) volume de gás carbônico produzido (VCO2), ( $\mathrm{E}$ e F) gasto energético (EE, $\left.\mathrm{kcal} / \mathrm{dia} / \mathrm{kg}^{\wedge} 0,75\right)$ e $(\mathrm{G} \mathrm{e} \mathrm{H}) \mathrm{RQ}(\mathrm{VCO} 2 / \mathrm{VO} 2)$. Valores em $\mathrm{mL} / \mathrm{min} / \mathrm{Kg}^{\wedge} 0,75$. Média $\pm \mathrm{EPM}$. ${ }^{\mathrm{a}} \mathrm{P}<0,05$ vs controle, ${ }^{\mathrm{b}} \mathrm{P}<0,05$ vs CLA.

Figura 20: Monitoramento da atividade motora horizontal e vertical dos camundongos durante 24 horas, separado em fase claro e fase escuro. (A e B) atividade locomotora horizontal; (C e D) atividade motora vertical (levantamento). Média \pm EPM. a $\mathrm{P}<0,05$ vs controle, ${ }^{b} \mathrm{P}<0,05$ vs CLA. $n=4-5$.

Figura 21: (A) curva glicêmica dos animais controle e suplementados com CLA e OP somente ou em conjunto, durante 120 minutos. (B) medida da área sob a curva do TTG (C) curva de decaimento da concentração de glicose plasmática nos animais controle e suplementados com CLA e OP somente ou em conjunto nos primeiros 20 minutos após a injeção de insulina. (D) gráfico da velocidade constante de desaparecimento da glicose plasmática $\left(\mathrm{K}_{\mathrm{itt}}\right)$. Média $\pm \mathrm{EPM}$. ${ }^{\mathrm{a}} \mathrm{P}<0,05$ vs controle, ${ }^{\mathrm{b}} \mathrm{P}<0,05$ vs CLA, ${ }^{\mathrm{c}} \mathrm{P}<0,05$ vs OP. $\mathrm{n}=4-5$.

Figura 22: Concentração dos lipídeos plasmáticos circulantes em camundongos suplementados com CLA e OP somente e em conjunto e controle; (A) colesterol total e (B) colesterol HDL e (C) triglicérides Média \pm EPM. ${ }^{a} \mathrm{P}<0,05$ vs controle. $\mathrm{n}=5$. 
Figura 23: gráficos representando a razão entre o peso dos tecidos e o peso corporal de camundongos suplementados CLA, OP, CLA + OP e controle. (A) tecido adiposo branco (B) tecido adiposo marrom; (C) cérebro; (D) músculo gastrocnêmio; (E) músculo sóleo e (F) fígado. Média \pm EPM. ${ }^{\mathrm{a}} \mathrm{P}<0,05$ vs controle, ${ }^{\mathrm{b}} \mathrm{P}<0,05$ vs CLA, ${ }^{\mathrm{c}} \mathrm{P}<0,05$ vs OP. $\mathrm{n}=5-15$.

Figura 24: Taxas respiratórias de mitocôndrias isoladas $(0,5 \mathrm{mg} / \mathrm{mL})$ de fígado de camundongos tratados com CLA, OP, CLA + OP e controle, incubadas em meio de respiração na ausência (barras brancas) ou presença (barras pretas) de $2 \mu \mathrm{M}$ de LA. Velocidades de respiração de mitocôndrias energizadas com glutamato e malato no (A) estado III, e (C) estado IV, (E) CR (estado III/estado IV), (G) $\Delta \mathrm{CR}$, (I) razão ADP/O e (K) $\Delta \mathrm{ADP} / \mathrm{O}$. Velocidades de respiração de mitocôndrias energizadas com succinato no (B) estado III, e (D) estado IV, (F) $\mathrm{CR}$ (estado III/estado IV), (H) $\Delta \mathrm{CR},(\mathrm{J})$ razão $\mathrm{ADP} / \mathrm{O}$ e $(\mathrm{L}) \Delta \mathrm{ADP} / \mathrm{O}$. ( $\left.^{*}\right)$ diferença estatística com $\mathrm{P}<0,05 .{ }^{\mathrm{a}} \mathrm{P}<0,05$ vs controle. $\mathrm{n}=10-11$.

Figura 25: Taxa de $\beta$-oxidação de mitocôndrias isoladas de fígados de camundongos suplementados com CLA, OP, CLA + OP e controles. Média \pm EPM. a P $<0,05$ vs controle.

Figura 26: Razões entre as velocidades de ATP, oligomicina e CCCP obtidas na respiração de tecido hepático permeabilizado. (A) V ADP / V oligomicina; (B) V oligomicina / V CCCP. Média \pm EPM. a $\mathrm{P}<0,05$ vs controle, $\mathrm{b} \mathrm{P}<0,05$ vs $\mathrm{CLA},{ }^{\mathrm{c}} \mathrm{P}<0,05$ vs $\mathrm{OP} . \mathrm{N}=5-6$.........54

Figura 27: Quantificação de RNAm de UCP2 de fígado de camundongos suplementados com CLA, OP, CLA + OP e controle, determinada por real time PCR (RT-PCR) e normalizadas pela expressão do gene constitutivo $\beta$-actina. Média \pm EPM. ${ }^{a} \mathrm{P}<0,05$ vs controle.

Figura 28: Atividade da citrato sintase em tecido hepático de camundongos suplementados com CLA, OP, CLA + OP e controle. Média \pm EPM. a P < 0,05 vs controle, b P < 0,05 vs CLA.

Figura 29: Geração de EROs em mitocôndrias isoladas de fígados de camundongos suplementados com CLA, OP, CLA + OP e controle. (A) Traçado representativo do ensaio da geração de EROs. (B) mitocôndrias energizadas com glutamato/malato e (C) succinato e rotenona. Média \pm EPM. ${ }^{a} \mathrm{P}<0,05$ vs controle, ${ }^{b} \mathrm{P}<0,05$ vs CLA.

Figura 30: Geração de EROs no tecido hepático permeabilizado de camundongos suplementados com CLA, OP, CLA + OP e controle. Média \pm EPM. a P < 0,05 vs controle. 57

Figura 31: Parâmetros indicativos do estado redox do fígado de camundongos suplementados com CLA, OP, CLA + OP e controle. (A) concentração de proteínas carboniladas e (B) razão entre glutationa reduzida e oxidada. Média \pm EPM. a $\mathrm{P}<0,05$ vs controle, b $\mathrm{P}<0,05$ vs CLA, c $\mathrm{P}<0,05$ vs OP.

Figura 32: Razões entre as velocidades de ATP, oligomicina e CCCP obtidas na respiração de biópsia de sóleo permeabilizado. (A) V ADP / V oligomicina; (B) V oligomicina / V CCCP.

Figura 33: Razões entre as velocidades de ATP, oligomicina e CCCP obtidas na respiração de biópsia de hipocampo permeabilizado. (A) V ADP / V oligomicina; (B) V oligomicina / V CCCP. Média \pm EPM.a $\mathrm{P}<0,05$ vs controle, b $\mathrm{P}<0,05$ vs CLA, c $\mathrm{P}<0,05$ vs OP. 
Figura 34: Quantificação dos níveis de RNAm de UCP2 no sóleo de camundongos suplementados com CLA, OP, CLA + OP e controle, determinada por real time PCR (RT-PCR) e normalizadas pela expressão do gene constitutivo $\beta$-actina. Média \pm EPM. ${ }^{a} \mathrm{P}<0,05$ vs

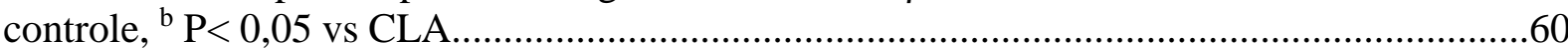

Figura 35: Atividade da citrato sintase em do sóleo de camundongos suplementados com CLA, OP, CLA + OP e controle. Média \pm EPM. ${ }^{a} \mathrm{P}<0,05$ vs controle, ${ }^{b} \mathrm{P}<0,05$ vs CLA, ${ }^{\mathrm{c}} \mathrm{P}<0,05$ OP.

Figura 36: Quantificação de RNAm de PGC1- $\alpha$ no sóleo de camundongos suplementados com CLA, OP, CLA + OP e controle, determinada por real time PCR (RT-PCR) e normalizadas pela expressão do gene constitutivo $\beta$-actina. Média \pm EPM. ${ }^{a} \mathrm{P}<0,05$ vs controle, ${ }^{b} \mathrm{P}<0,05$ vs CLA.

Figura 37: Razões entre as velocidades de ATP, oligomicina e CCCP obtidas na respiração de biópsia de hipocampo permeabilizado. (A) V ADP / V oligomicina; (B) V oligomicina / V CCCP. Média \pm EPM. ${ }^{\mathrm{a}} \mathrm{P}<0,05$ vs controle, ${ }^{\mathrm{b}} \mathrm{P}<0,05$ vs CLA $,{ }^{\mathrm{c}} \mathrm{P}<0,05$ vs OP 62

Figura 38: Geração de EROs em tecido hipocampal permeabilizado de camundongos tratados com CLA, OP, CLA + OP e controle. Média \pm EPM. $^{a} \mathrm{P}<0,05$ vs controle, ${ }^{\mathrm{b}} \mathrm{P}<0,05$ vs CLA.

Figura 39: (A) Quantificação de RNAm de UCP5 determinada por real time PCR (RT-PCR) e normalizadas pela expressão do gene constitutivo $\beta$-actina e (B) atividade da citrato sintase no hipocampo de camundongos suplementados com CLA, OP, CLA + OP e controle. Média \pm EPM. ${ }^{\text {a }} \mathrm{P}<0,05$ vs controle 


\section{LISTA DE TABELAS}

Tabela 1: Periodização da suplementação dos quatro grupos experimentais com seus respectivos ácidos graxos. A suplementação foi feita durante um período de 60 dias.............25

Tabela 2: Volumes de cada reagente utilizado para a dosagem de proteínas através do método colorimétrico do Biureto. 30

Tabela 3: Sequência de nucleotídeos dos primers utilizados para a quantificação de mRNA dos genes da UCP-2, UCP-5, PGC1- $\alpha$ e $\beta$-actina. 


\section{LISTA DE ABREVIATURAS E SÍMBOLOS}

$\mu \mathrm{L}$

Microlitros

$\mu \mathrm{M}$

Micromolar

ADP

Adenosina difosfato

AG

Ácido graxo

ANOVA

Análise de variância

ATP

Adenosina trifosfato

BSA

Soro albumina bovino

HEPES

Ácido 2- [4- (2-hidroxietil) piperazin-1-il] etanossulfônico

$\mathrm{CCCP}$

Carbonil cianeto m-clorofenilhidrazona

cDNA

Ácido desoxirribonucléico complementar

CEUA

Comissão de Ética no Uso de Animais

CLA

Ácido linoleico conjugado

CONCEA

Conselho Nacional de Controle de Experimentação Animal

CPT

Carnitina palmitoil transferase

CTE

Cadeia transportadora de elétrons

DHA

Ácido docosahexaenóico

DNFH

Dinitrofenilhidrazina

dNTP

Desoxirribonucleotídeos fosfatados

DTNB

Ácido ditiobis-2-nitrobeizóico

DTT

Ditiotreitol

$\mathrm{EE}$

Gasto energético (energy expenditure)

EGTA

Ácido bis (2 amino etil) etilenoglicol tetra-ácetico

EPA

Ácido eicosapentaenoico

EPM

Erro padrão da média

EROs

Espécies reativas de oxigênio

$\mathrm{GSH}$

Glutationa reduzida

GSSH

Glutationa oxidada

$\mathrm{H}_{2} \mathrm{O}_{2}$

Peróxido de hidrogênio

HDL

Lipoproteína de alta densidade (high density lipoprotein)

HRP

Horseradish peroxidase

$\mathrm{KCl}$

Cloreto de potássio 
$\mathrm{K}_{\mathrm{itt}}$

K-MES

$\mathrm{KOH}$

LA

M

mg

$\mathrm{MgCl}_{2}$

MIR 05

$\mathrm{mL}$

$\mu \mathrm{g} / \mathrm{mL}$

mRNA

NEM

$\mathrm{nm}$

${ }^{\circ} \mathrm{C}$

OMS

OP

OPT

PCR

PGC1- $\alpha$

PPAR

PUFA

RNA

rpm

RQ

TAB

TAM

TCA

TTG

TTI

UCP

UI

$\mathrm{VCO}_{2}$

$\mathrm{VO}_{2}$
Constante da taxa de desaparecimento da glicose plasmática

Ácido 2-(N-morfolino) etanosulfônico

Hidróxido de potássio

Ácido linoleico

$\mathrm{Mol} / \mathrm{L}$

Miligramas

Cloreto de magnésio

Mitomed R05

Mililitros

Milimolar

RNA mensageiro

N-etil-maleimida

Nanômetros

Graus Celsius

Organização Mundial da Saúde

Óleo de peixe

Orto fitaldeído

Polimerase chain reaction (Reação em cadeia da polimerase)

Peroxisome proliferator-activated receptor gamma coactivator 1- $\alpha$

Peroxisome proliferator-activated receptor

Ácido graxo poli-insaturado (Polyunsatured Fatty Acid)

Ácido ribonucléico

Rotações por minuto

Coeficiente respiratório

Tecido adiposo branco

Tecido adiposo marrom

Ácido tricloacético

Teste de tolerância a glicose

Teste de tolerância a insulina

Proteína desacopladora mitocondrial

Unidades de insulina

Volume de gás carbônico

Volume de oxigênio 


\section{SUMÁRIO}

INTRODUÇÃ

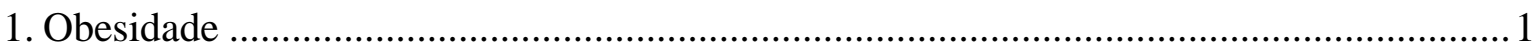

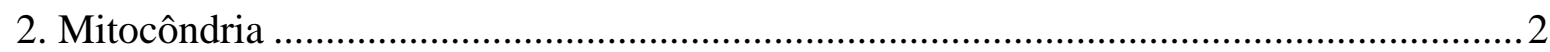

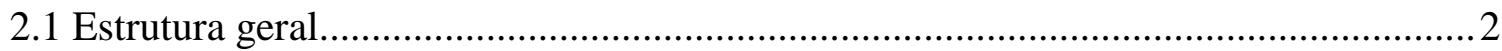

2.2 Cadeia transportadora de elétrons e fosforilação oxidativa........................................

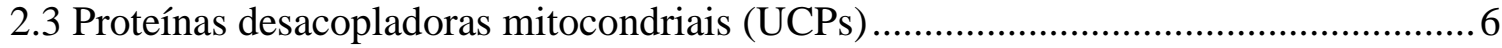

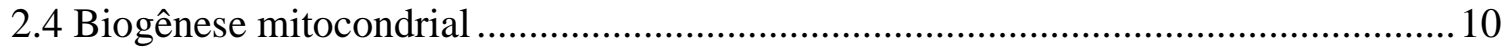

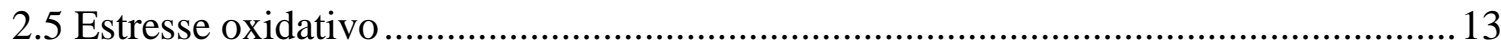

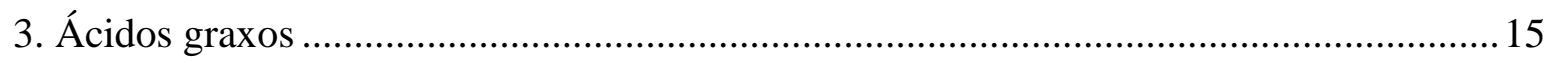

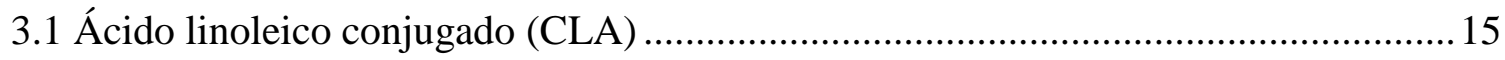

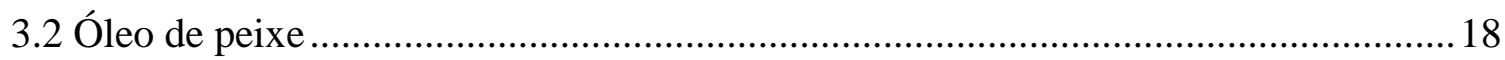

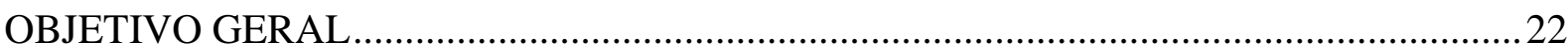

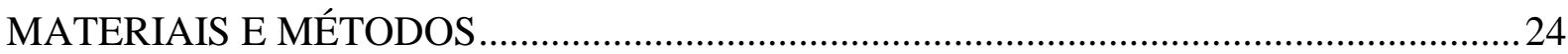

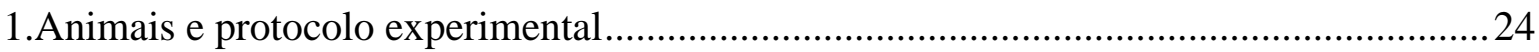

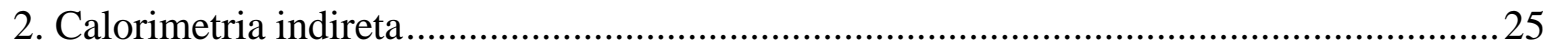

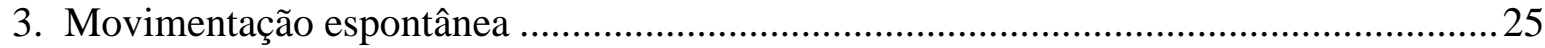

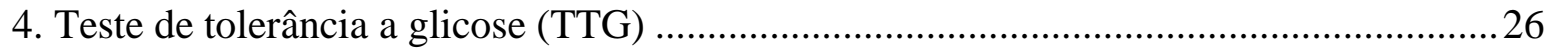

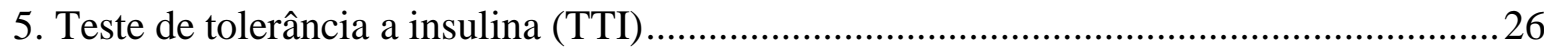

6. Determinação da concentração plasmática de lipídeos ..................................................2 27

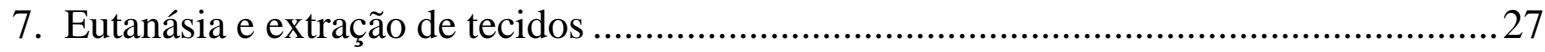

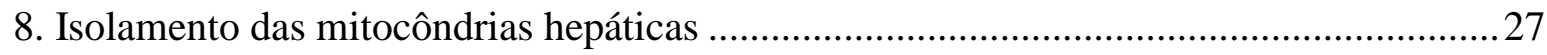

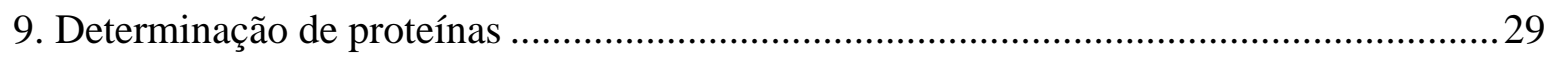

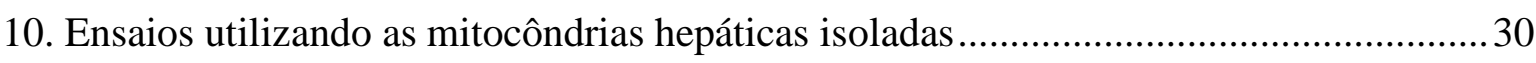

10.1 Composição do meio de respiração utilizado para os ensaios .................................. 30

10.2 Determinação do consumo de oxigênio das mitocôndrias isoladas de fígado ..........30

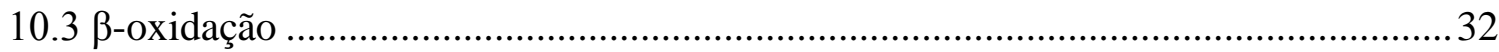


10.4 Produção de espécies reativas de oxigênio (EROs) mitocondrial 32

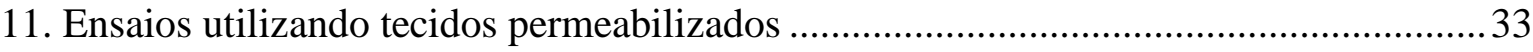

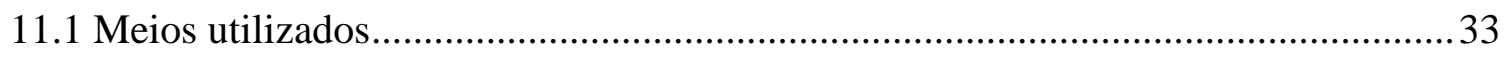

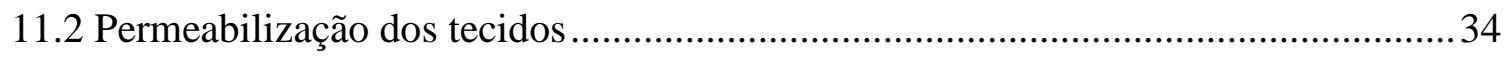

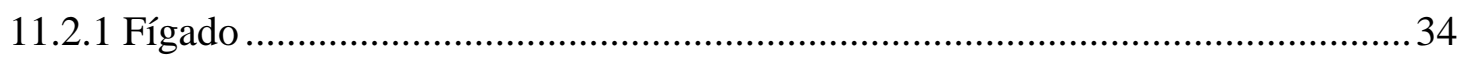

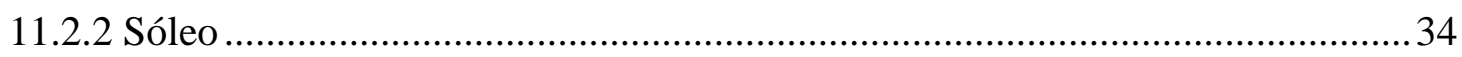

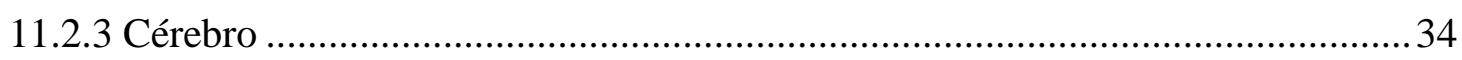

11.3 Determinação do consumo de oxigênio dos tecidos............................................... 34

11.4 Produção de espécies reativas de oxigênio (EROs) em tecidos permeabilizados .... 35

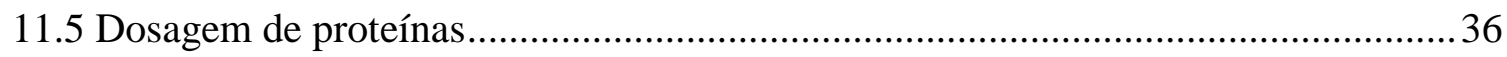

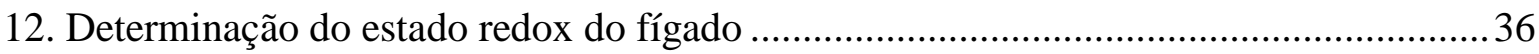

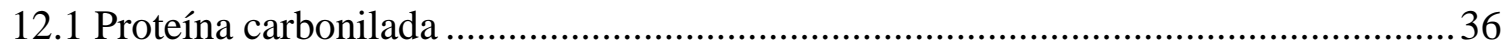

12.2 Relação Glutationa reduzida (GSH) e glutationa oxidada (GSSG) ...........................37

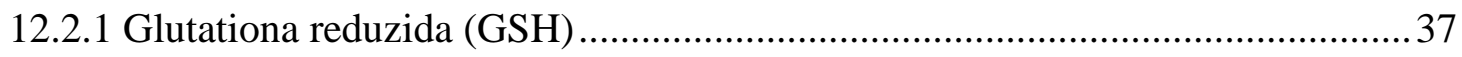

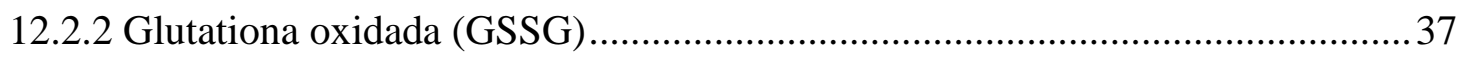

13. Quantificação de mRNA de UCP-2 no fígado, UCP-5 no cérebro e PGC1- $\alpha$ no sóleo. 38

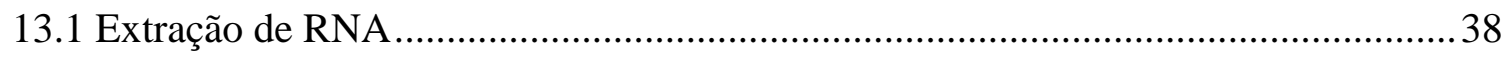

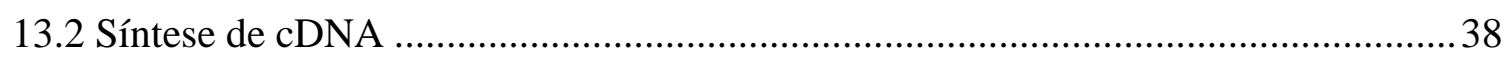

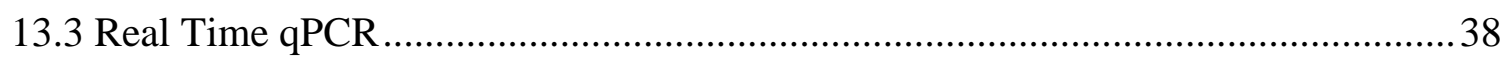

14 - Ensaio de cinética enzimática para determinação da atividade da citrato sintase ......... 39

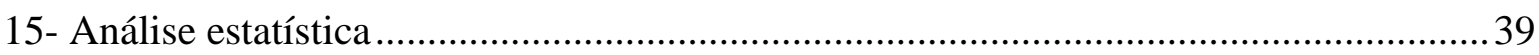

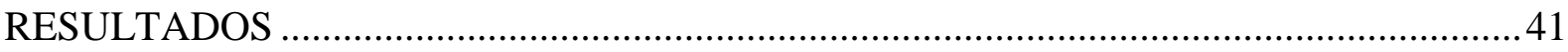

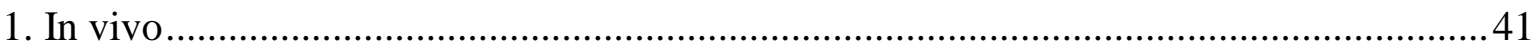

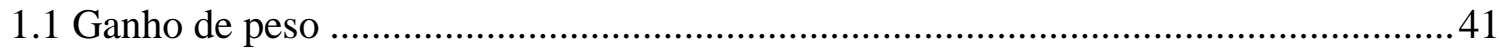

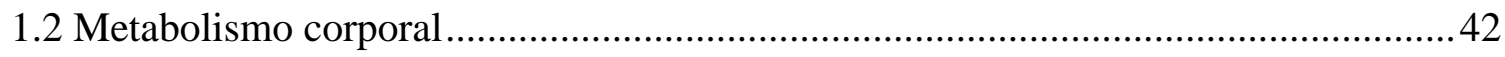

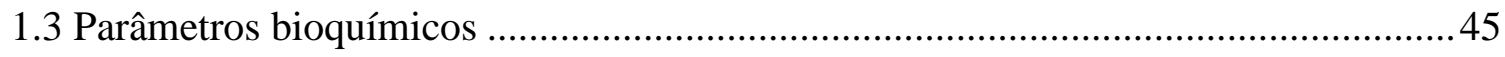

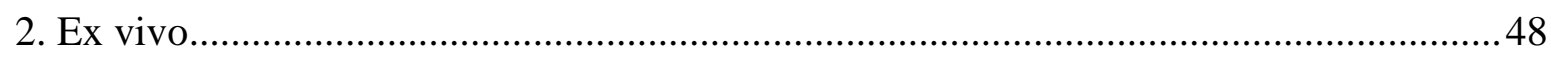




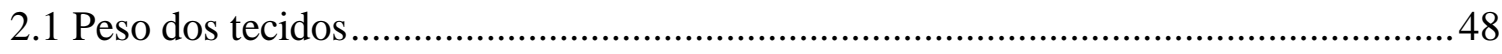

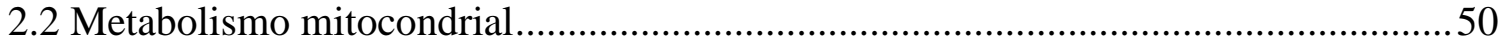

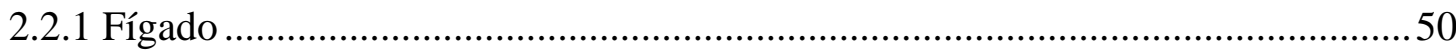

2.2.1.1 Consumo de oxigênio do tecido hepático permeabilizado e de mitocôndrias

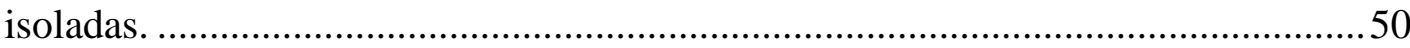

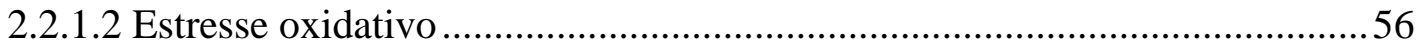

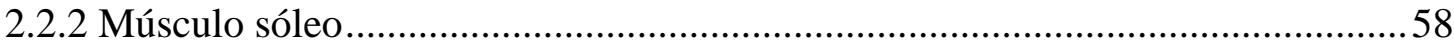

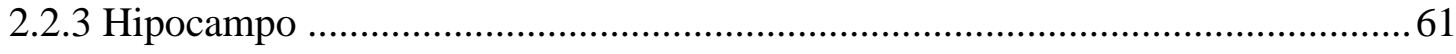

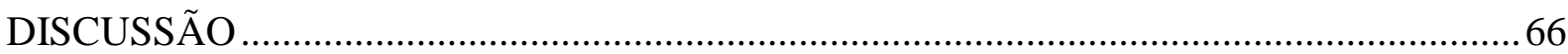

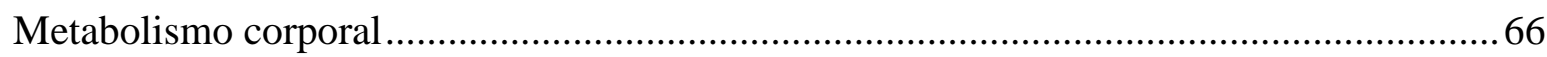

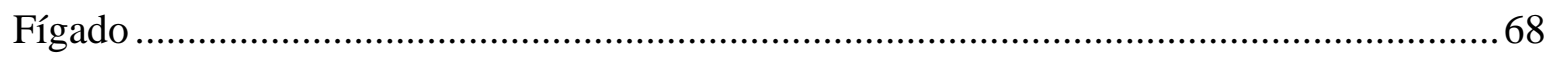

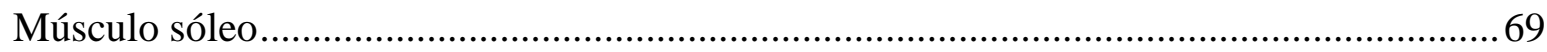

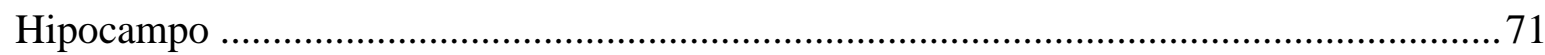

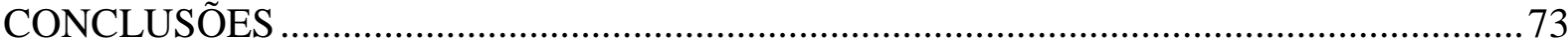

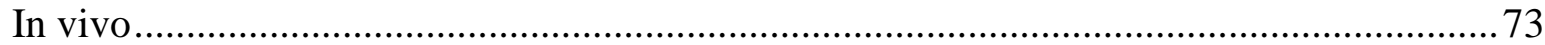

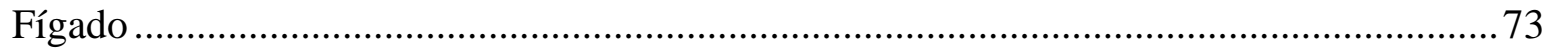

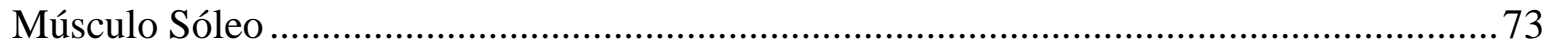

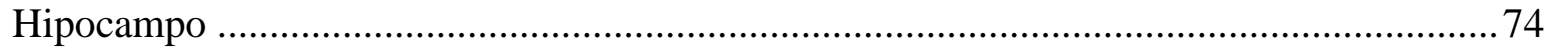

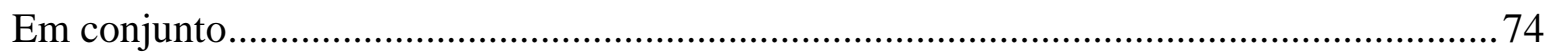

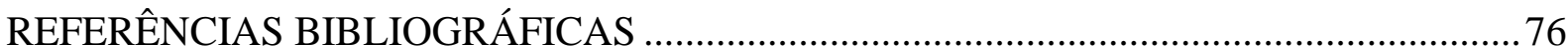




\section{Introdusãa}




\section{INTRODUÇÃO}

\section{Obesidade}

A obesidade é definida de forma geral como o acúmulo excessivo de gordura corporal que pode causar o surgimento de vários problemas de saúde como hipertensão, problemas cardíacos, diabetes, dislipidemias, entre outros. É considerada pela Organização Mundial da Saúde (OMS) uma doença integrante do grupo de doenças crônicas não-transmissíveis. Elas não têm cura, mas controle, e por isso a prevenção deve se tornar a maior estratégia contra a obesidade. Segundo a OMS, depois do tabagismo, a obesidade é considerada a segunda causa de morte passível de prevenção (WHO CONSULTATION ON OBESITY., 2000).

Em uma pesquisa divulgada em 2015 pelo IBGE mostra que no Brasil mais da metade da população adulta (56,9\%) está com excesso de peso e 20,8\% estão obesos (IBGE, 2015). Se a população não adotar hábitos mais saudáveis, estima-se que em 2030, em todo o mundo, o número de adultos com sobrepeso e obesidade será de 2,16 bilhões e 1,12 milhões, respectivamente (KELLY et al., 2008). A obesidade é uma epidemia que atinge todos os níveis socioeconômicos, tanto nos países desenvolvidos quanto nos em desenvolvimento. Essa condição é hoje uma realidade mundial que se encontra em evidente crescimento, sendo considerada a epidemia do século XXI, contribuindo para as taxas de morbidade e mortalidade na população. (PEREIRA, 2007).

É uma condição causada pela combinação entre pré-disposição genética e estilo de vida. A inatividade física e a alimentação inadequada resultam em um balanço energético positivo, que ocorre quando o valor calórico ingerido é superior ao gasto promovendo aumento nos estoques de energia e peso corporal (PEREIRA; FRANCISCHI; LANCHA JR., 2003). Sendo assim, para reduzir o peso é preciso que haja um déficit energético com diminuição da ingestão alimentar além do aumento significativo da atividade física (OLIVEIRA; ALMEIDA, 2012). No entanto, dependendo da condição é aconselhável a intervenção medicamentosa e nos casos mórbidos a cirurgia bariátrica (NUNES et al., 2006). Como alternativa de tratamento e prevenção, diversos estudos têm mostrado o uso de ácidos graxos que possuem habilidade de expressar genes que possuem um importante papel em modulações metabólicas e mitocondriais (WARGENT et al., 2005; MORI et al., 2007; ROHRBACH, 2009) . 


\section{Mitocôndria}

\subsection{Estrutura geral}

Há mais de 50 anos as mitocôndrias tem sido objeto de investigação de pesquisadores em todo o mundo devido a sua grande importância funcional. Em 1949, Lehninger e Kennedy demonstraram que o ciclo de Krebs, a oxidação de ácidos graxos e a fosforilação oxidativa ocorrem nas mitocôndrias (NADEGE, B., PATRICK, L., ROSSIGNOL, 2009). Estas organelas são essenciais no aspecto regulador do metabolismo energético e por isso alterações nas funções mitocondriais são ligadas a desordens metabólicas, como obesidade e diabetes mellitus tipo 2 (NISOLI et al., 2007; ESPOSTI et al., 2015).

O perfil metabólico possivelmente evoluiu com a incorporação de procariotos ( $\alpha$ proteobactéria) em um ambiente inicialmente oxigenado por células primitivas, originando assim, uma elegante relação simbiótica entre célula hospedeira e mitocôndrias (SCHWARTZ; DAYHOFF, 1978; LAKE, 2015). As células hospedeiras se tornaram dependentes dessas organelas uma vez que, para realizar diversos processos bioquímicos, se faz necessária a utilização de ATP e a grande maioria dessa fonte energética é obtida nas mitocôndrias. Sem elas, as atuais células animais seriam dependentes da glicólise anaeróbia para produzir todo seu ATP (ALBERTS, 2010).

As mitocôndrias são organelas semiautônomas, possuem ribossomos e seu próprio DNA (mtDNA), sintetizando algumas de suas proteínas, uma vez que a maioria das proteínas mitocondriais são sintetizadas por genes nucleares. Enquanto aproximadamente 1500 proteínas mitocondriais são codificadas no núcleo, o genoma mitocondrial codifica 13 subunidades essenciais da fosforilação oxidativa (WENZ, 2013).

Estruturalmente as mitocôndrias são descritas como cilindros rígidos e alongados com diâmetro de 0,5 a $1 \mu \mathrm{m}$ e podem se autorreplicar a partir de uma mitocôndria pré-existente. Elas podem formar longos filamentos móveis ou podem permanecer fixas fornecendo ATP diretamente nos locais onde o consumo é mais elevado. (MCBRIDE; NEUSPIEL; WASIAK, 2006; KARP, 2013). Como mostra a Figura 1, cada mitocôndria é formada por duas membranas biológicas, as quais selecionam os compostos a serem incorporados e/ou oxidados. A membrana mitocondrial externa é altamente permeável a pequenas moléculas e íons que se movem através da membrana por uma família de proteínas integrais denominadas porinas. A membrana interna é impermeável a pequenas moléculas e íons, inclusive os íons $\mathrm{H}^{+}$. A única forma de atravessar esta membrana é através de transportadores específicos. A membrana dupla 
delimita um espaço intermembranar, que possui uma alta concentração de íons $\mathrm{H}^{+}$, e o espaço interno que é denominado matriz, onde se encontram as enzimas do metabolismo oxidativo e as cristas mitocondriais que contém os componentes da cadeia transportadora de elétrons e a ATPsintase (GEORGE; PALADE, 1953; FREY; RENKEN; PERKINS, 2002; KARP, 2013; NELSON; COX, 2014).

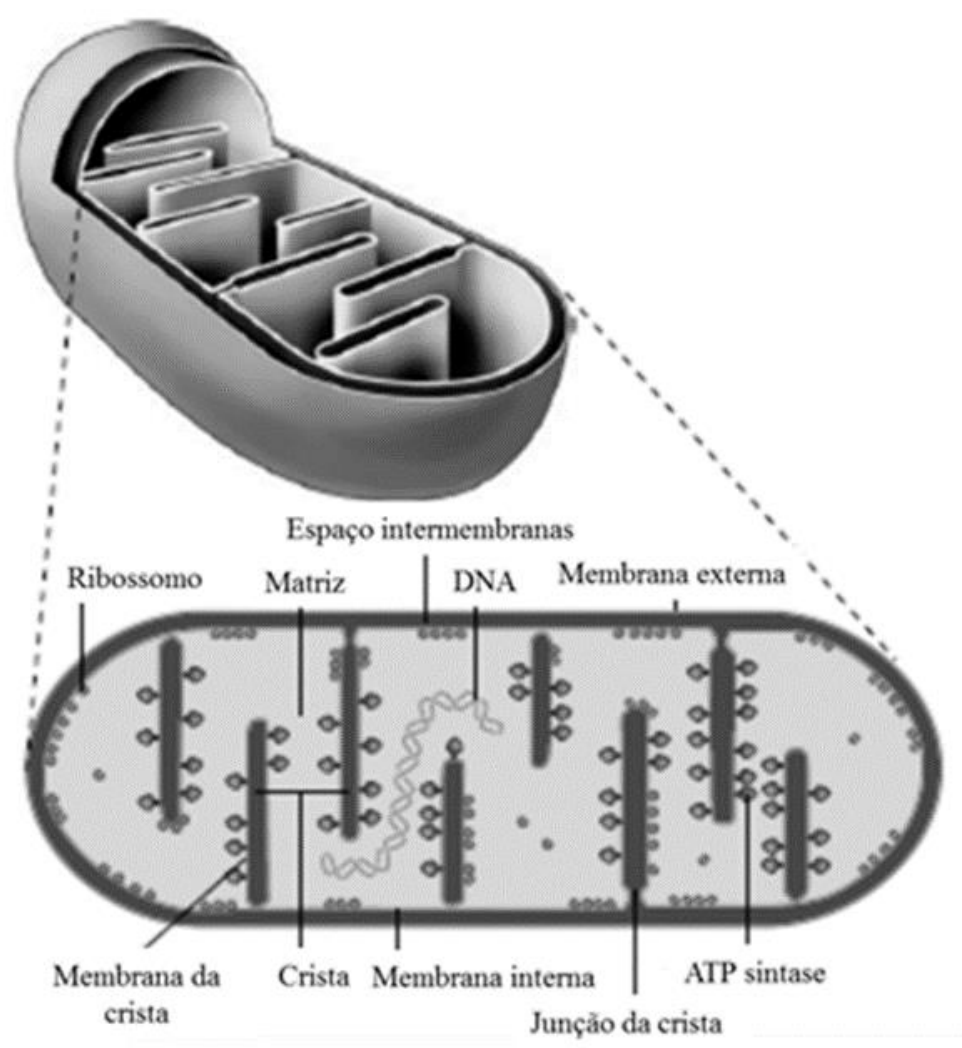

Figura 1: Estrutura morfológica da mitocôndria. As setas mostram a membrana externa, a membrana interna, a matriz mitocondrial, os ribossomos, o espaço intermembranas, as cristas mitocondriais, o DNA mitocondrial (mtDNA) e a ATP sintase presente na membrana interna que é responsável pela síntese de ATP (Figura retirada e modificada de KARP, 2013).

\subsection{Cadeia transportadora de elétrons e fosforilação oxidativa}

As mitocôndrias são organelas responsáveis pela geração de energia química, na forma de ATP. Este processo é denominado fosforilação oxidativa e envolve uma série de complexos transportadores de elétrons e a enzima ATP sintase, que estão localizados na membrana interna mitocondrial (NELSON; COX, 2014).

A cadeia transportadora de elétrons (CTE) é constituída por quatro complexos proteicos denominados de NADH-coenzima Q redutase (complexo I), succinato coenzima Q redutase (complexo II), ubiquinol citocromo C redutase (complexo III) e citocromo C oxidase (complexo 
VI). Além desses componentes da CTE duas moléculas de ligação móveis contribuem no transporte de elétrons: uma quinona lipofílica chamada de coenzima $Q$ ou ubiquinona que se encontra embebida na bicamada lipídica; e uma proteína hidrofílica contendo um grupo heme chamado de citocromo $c$, localizado na superfície externa da membrana interna da mitocôndria (LENAZ; GENOVA, 2009). Além disso, juntamente a CTE encontra-se a ATP sintase (também chamada de complexo V) que catalisa a formação de ATP a partir da adição de Pi ao ADP. Estes complexos respiratórios estão dispostos em uma orientação especifica, sequenciados em função do seu potencial redox (SAPRA; BAGRAMYAN; ADAMS, 2003).

A fosforilação oxidativa se inicia com a entrada dos elétrons provenientes da coenzima reduzida NADH na CTE através do complexo I que catalisa a transferência de dois elétrons do $\mathrm{NADH}$ para a flavina mononucleotídeo (FMN) e adquire a forma reduzida $\mathrm{FMNH}_{2}$. Em seguida estes elétrons passam por uma série de centros ferro-enxofre e são transferidos para a coenzima $\mathrm{Q}(\mathrm{CoQ})$, que na sua forma reduzida $\left(\mathrm{CoQH}_{2}\right)$, se difunde na bicamada lipídica até o complexo III. Esta transferência de elétrons faz com que o complexo I, visto que é uma proteína transmembrana, bombeie quatro prótons da matriz para o espaço intermembranas (SCHULTZ; CHAN, 2001; SAPRA; BAGRAMYAN; ADAMS, 2003; LENAZ; GENOVA, 2009; NELSON; COX, 2014).

Semelhantemente aos mecanismos de oxido-redução que ocorrem no complexo I, o complexo II também transfere elétrons para a CoQ através da oxidação de succinato, porém não há bombeamento de prótons pelo fato desta unidade da CTE ser uma proteína periférica, ou seja, tratar-se de uma classe de proteínas de membrana, as quais estão ancoradas em uma única lamina da membrana biológica, sendo assim impedidas de transportar íons (SCHULTZ; CHAN, 2001; SAPRA; BAGRAMYAN; ADAMS, 2003; STRYER, 2014; LENAZ; GENOVA, 2009; NELSON; COX, 2014).

O próximo passo é a transferência dos elétrons do $\mathrm{CoQH}_{2}$ para o citocromo $c$ que é intermediada pelo complexo III e com o consequente bombeamento de mais quatro prótons para o espaço intermembranas. Por fim, no complexo IV ocorre a transferência dos elétrons do citocromo $c$ para o oxigênio molecular e o reduz à água. Neste processo há o bombeamento de dois prótons para o espaço intermembranas (SCHULTZ; CHAN, 2001; SAPRA; BAGRAMYAN; ADAMS, 2003; STRYER, 2014; LENAZ; GENOVA, 2009; NELSON; COX, 2014) com isso, finalizando o transporte de elétrons provenientes de substratos que foram oxidados. 
O rendimento dos substratos oxidados na cadeia respiratória gera para cada par de elétrons que entra no complexo I e II o bombeamento da matriz mitocondrial para o espaço intermembranas de dez e seis prótons, respectivamente. Essa diferença na concentração de prótons dentro e fora da matriz gera um gradiente elétrico devido à diferença de carga elétrica nos dois lados da membrana interna. A energia conservada nesse gradiente eletroquímico é chamada de força próton-motriz que é utilizada para sintetizar ATP pela ATP sintase. Os prótons bombeados para o espaço intermembranas tendem a retornar para a matriz, a favor do gradiente de concentração, mas como a membrana é impermeável eles passam através da ATPsintase, a qual utiliza a energia proporcionada pela continua passagem de prótons para fosforilar o ADP formando o ATP (NELSON; COX, 2014; ANDREA T. DA POIAN, 2015).

O processo de transporte de elétrons acoplado a síntese de ATP descrito acima, é conhecido como modelo quimiosmótico e foi proposto por Petter Mitchell em 1961 (Figura 2). A teoria de Mitchell também nos diz que o retorno de prótons a matriz que não seja pela ATP sintase ("vazamento" de prótons ou proton-leak) provoca o desacoplamento da respiração e a termogênese (MITCHELL, 1961). O desacoplamento pode ocorrer de duas formas: químico e fisiológico. O desacoplamento químico ocorre através da adição de substâncias desacopladoras de origem sintética, como o CCCP (carbonilcianeto m-clorofenil-hidrazona) e o DNP (2,4 dinitrofenol) e também por substancias de ocorrência natural, como o nemorosome, uma resina floral da Clusia rósea desacopladora de mitocôndrias isoladas do fígado de ratos (PARDOANDREU et al., 2011). O desacoplamento fisiológico acontece devido a presença da proteína desacopladora mitocondrial (UCP). 


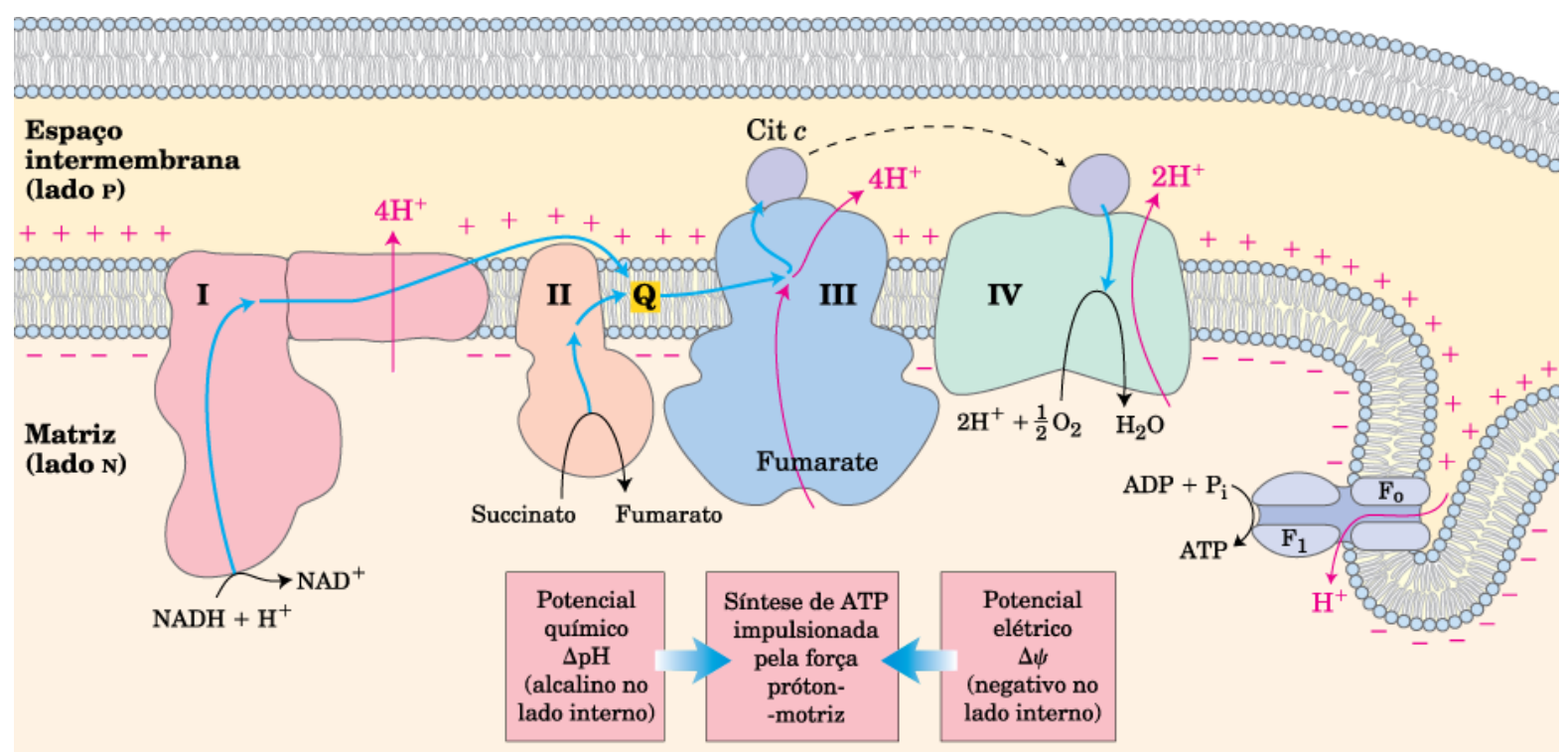

Figura 2: Modelo quimiosmótico proposto por Petter Mitchell em 1961. Elétrons do NADH e de substratos oxidáveis passam pelos complexos da cadeia transportadora de elétrons (CTE) localizados na membrana mitocondrial interna. O fluxo de elétrons é acompanhado pelo bombeamento de prótons produzindo um gradiente eletroquímico. A membrana é impermeável a prótons, por isso eles retornam a matriz mitocondrial por canais específicos como a ATPsintase. Essa força próton-motriz impulsiona a síntese de ATP (Figura retirada de NELSON; COX, 2011).

\subsection{Proteínas desacopladoras mitocondriais (UCPs)}

Fisiologicamente admite-se que a produção de calor nos animais possa ser dividida em duas categorias: termogênese obrigatória e termogênese facultativa. A termogênese obrigatória (metabolismo basal) é a somatória de todo o calor produzido no organismo em repouso, na temperatura ambiente e em jejum de pelo menos $12 \mathrm{~h}$. Este processo é resultado de processos fisiológicos involuntários como por exemplo batimentos cardíacos e movimentos respiratórios. A termogênese facultativa é todo o calor produzido além do metabolismo basal e promove a dissipação de energia por estímulos externos. Pode ser induzida pela estimulação do sistema nervoso simpático, administração de hormônios da tireóide, exposição ao frio e ingestão alimentar (MATAMALA et al., 1996; BIANCO, 2000; BOSCHINI; GARCIA, 2005; SHABALINA et al., 2013).

As proteínas desacopladoras mitocondriais localizam-se na membrana interna da mitocôndria e atuam no controle da termogênese adaptativa, balanço energético e da produção de espécies reativas de oxigênio (ROS). São canais transportadores de prótons e fornecem uma via alternativa de passagem de prótons do espaço intermembranas para a matriz sem passar pela ATP sintase (Figura 3). Como resultado, a energia de oxidação não é conservada para formação 
de ATP, mas é dissipada em forma de calor, o qual contribui para a manutenção da temperatura corporal (NELSON; COX, 2014). Estima-se que este vazamento de prótons possa atingir até $40 \%$ da energia de oxidação, resultando em um desacoplamento fisiológico (BIANCO, 2000). O desacoplamento é um processo que possui grande influência no metabolismo energético e, variações neste processo contribuem para o desenvolvimento de obesidade e perda de peso, pois a manutenção do gradiente de prótons mitocondrial para a síntese de ATP leva a um aumento no consumo de substratos energéticos e na respiração mitocondrial (ROUSSET et al., 2004). Dessa forma as UCPs tem sido amplamente estudadas a fim de aumentar a taxa metabólica e tratar doenças relacionadas a bioenergética (BUSIELLO; SAVARESE; LOMBARDI, 2015).

As UCPs foram inicialmente denominadas de termogeninas. Porém, após a sua devida caracterização em tecido adiposo marrom a sigla UCP (uncoupling protein) passou a ser oficialmente empregada, sendo esta chamada de UCP1 (uncoupling protein 1). A UCP1 está diretamente envolvida com a principal função fisiológica do tecido adiposo marrom que é de termogênese e representa aproximadamente $10 \%$ do conteúdo de proteína mitocondrial. A termogênese no TAM é ativada em recém-nascidos, em roedores expostos ao frio e em animais que saem da hibernação (NICHOLLS, 2001; DEPIERI et al., 2004; BUSIELLO; SAVARESE; LOMBARDI, 2015). 


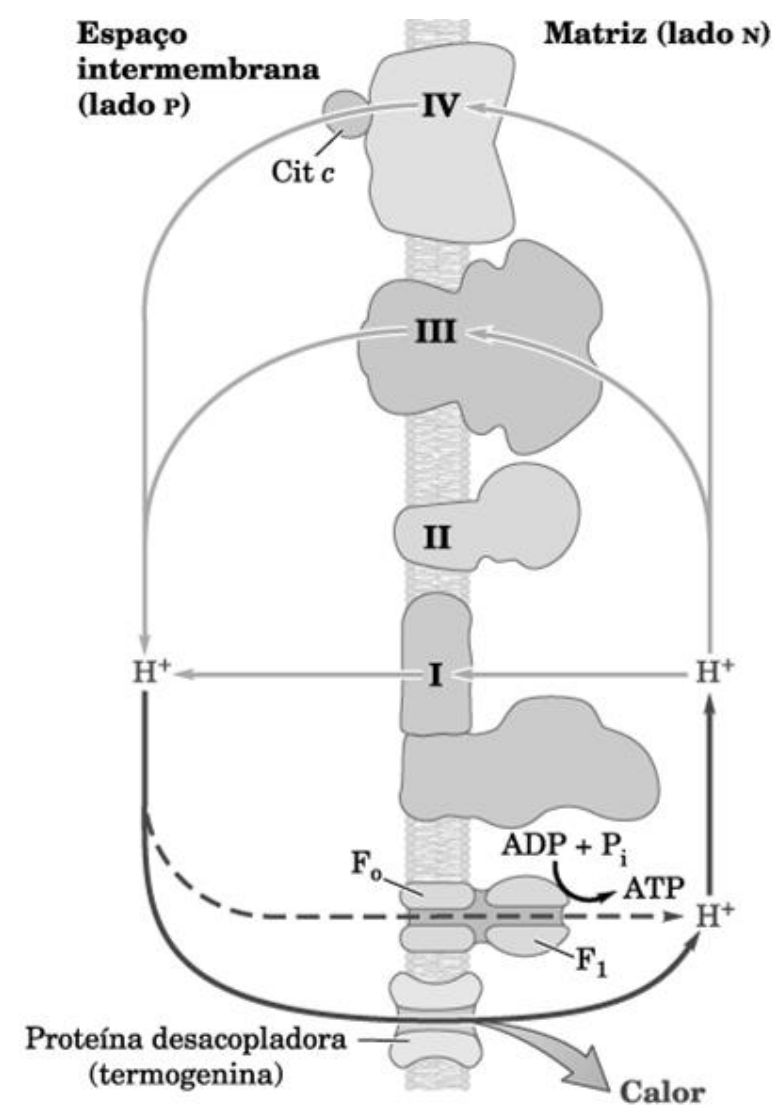

Figura 3: Produção de calor através do desacoplamento causado pela proteína desacopladora (UCP). As UCPs fornecem uma via alternativa para a reentrada de prótons na matriz e a energia é dissipada na forma de calor (Figura retirada de NELSON; COX, 2014).

Existem mecanismos propostos para explicar a translocação de prótons pela UCP1 utilizando ácidos graxos livres (AGLs). Uma possível estratégia de desacoplamento pela UCP envolvendo AGLs foi proposto em 1996 por GARLID et al. Sua hipótese é que as UCPs translocam ânions de ácidos graxos livres da matriz para o espaço intermembranas. Neste meio eles aceitam um próton e através de um movimento de "flip-flop" são capazes de atravessar a membrana e liberar o próton na matriz. O ânion retorna ao espaço intermembranar pela UCP e o ciclo se inicia novamente (Figura 4A) (GARLID et al., 1996; GARLID, 2000; ARECHAGA; LEDESMA; RIAL, 2001; GARLID; JABUREK; JEZEK, 2001).

Outro modelo proposto por Winkler e Klingenberg foi chamado de "modelo de tamponamento". Eles sugeriram que os AGLs agem como grupos prostéticos das UCPs se ligando a regiões no interior da proteína. Acredita-se que o papel dos AG seria compensar a falta de alguns grupos de aminoácidos tamponantes em locais essenciais da estrutura proteica. Os grupos carboxila dos AG e resíduos dos aminoácidos tamponantes atuariam como 
doadores/aceptores de prótons facilitando o transporte pelo canal. (Figura 4B) (WINKLER; KLINGENBERG, 1994; ARECHAGA; LEDESMA; RIAL，2001; KRAUSS; ZHANG; LOWELL, 2005).

(A)

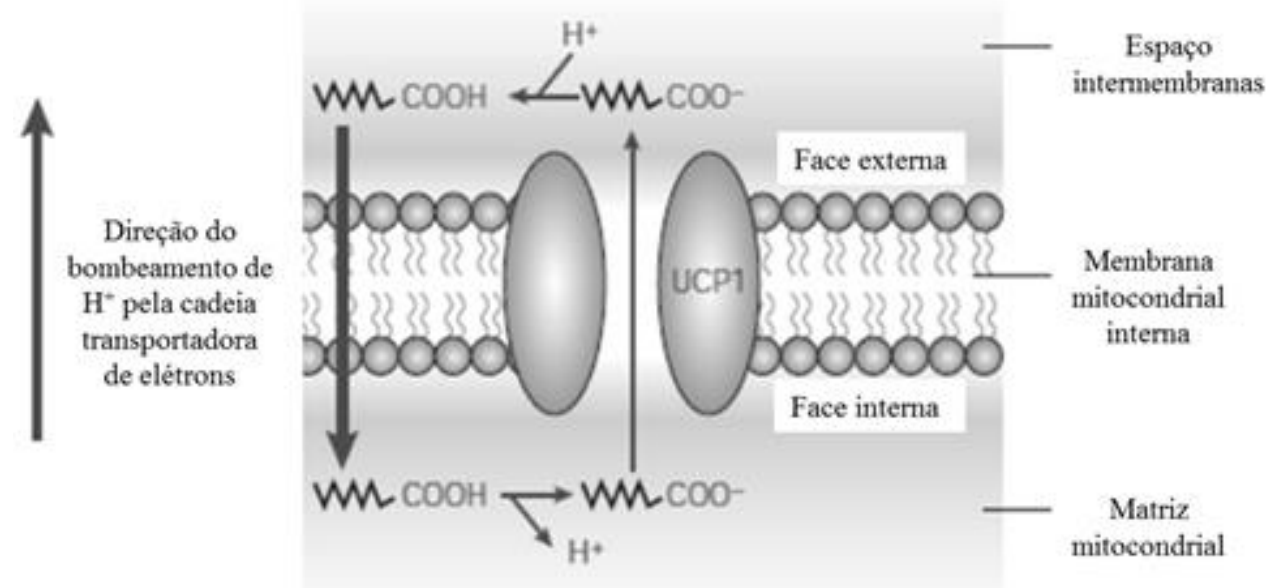

(B)

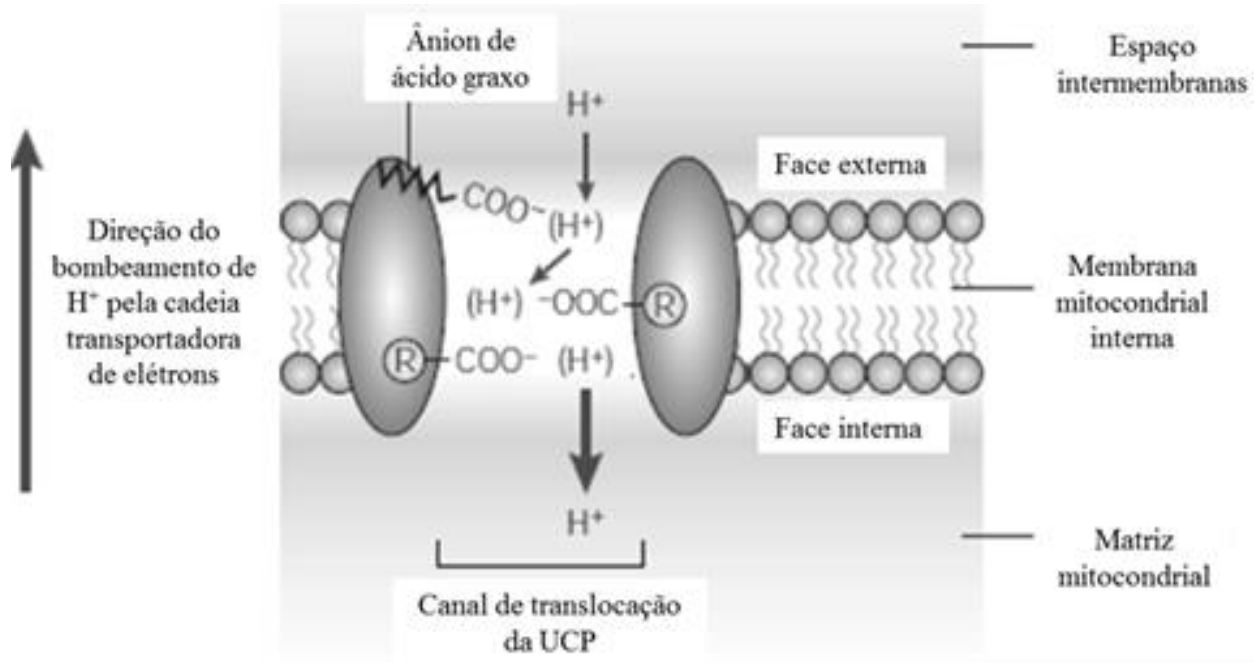

Figura 4: Esquemas dos mecanismos de desacoplamento das UCPs utilizando ácidos graxos livres como substrato. (A) Mecanismo proposto por GARLID et al., 1996. (B) Mecanismo proposto por Winkler e Klingenberg (Figura retirada e modificada de KRAUSS; ZHANG; LOWELL, 2005)

Além da UCP1 foram encontradas outras isoformas que são expressas nos demais tecidos e foram denominadas UCP2, UCP3, UCP4 e UCP5 (também chamada de BMCP1 - 
brain mitochondrial carrier protein-1). Enquanto a UCP3 concentra-se no musculo esquelético, a UCP2 é expressa em vários órgãos, principalmente no fígado, e tem demonstrado ser importante na produção de radicais livres de oxigênio (PEREIRA et al., 2012; BARALDI et al., 2016), defesa contra infecções (PUIGSERVER et al., 2001) e a secreção de insulina no pâncreas (ZHANG et al., 2001). No tecido adiposo, os ácidos graxos estimulam a expressão dos genes das UCPs 2 e 3 através da interação com receptores PPARs e estão relacionadas com regulação do metabolismo, consumo de substratos energéticos e controle de peso (AUBERT et al., 1997; ARMSTRONG; TOWLE, 2001; BOSCHINI; GARCIA, 2005). As UCP4 e UCP5 são encontradas sobretudo no cérebro (YU et al., 2000; ALÁN et al., 2009). Neste tecido admite-se que elas possuem função de reduzir o estresse oxidativo e consequentemente exercer efeito protetor sobre o órgão (KIM-HAN et al., 2001; RAMSDEN et al., 2012). A literatura dispõe de trabalhos que sugerem que as UCPs são ativadas por radicais superóxidos produzidos pela cadeia transportadora de elétrons (ECHTAY et al., 2002; ESTEVES et al., 2004). Além disso, estudos mostram que também são expressas em resposta à dieta cetogênica (SULLIVAN et al., 2004) e à exposição ao frio (YU et al., 2000).

\subsection{Biogênese mitocondrial}

O ciclo de vida mitocondrial começa com crescimento e divisão das organelas préexistentes (biogênese) e termina com a degradação de organelas danificadas por mitofagia. Durante este ciclo, as mitocôndrias são submetidas a ciclos frequentes, que permitem gerar múltiplas mitocôndrias heterogêneas (fỉssão) ou redes interconectadas mitocondriais (fusão) (Figura 5), dependendo das condições fisiológicas. Este processo se baseia na síntese de proteínas codificadas pelo genoma nuclear e mitocondrial e é acompanhada por variações em número, tamanho e massa em resposta a estímulos externos, como por exemplo, frio, exercício físico e dieta (CLAPIER, V.; GARNIER, A.; VEKSLEY, 2008; HOCK; KRALLI, 2009; WESTERMANN, 2010).

Durante a fusão as membranas externas e internas, que delineiam uma mitocôndria, se fundem com as membranas correspondentes na outra mitocôndria, sendo as mitofusinas (Mfn) e a Opa1 (optic atrophy-1) responsáveis pela fusão das membranas externas e internas respectivamente (CHAN, 2011). Por outro lado, a fissão consiste em uma constrição causada por proteínas de fissão (Fis1, Drp1 e Mff) que dividem as membranas externa e interna resultando em duas organelas (CHAN, 2011; WESTERMANN, 2012). As mitocôndrias fundidas são favorecidas quando a função mitocondrial ótima é necessária. Assim, são 
frequentemente encontrados em células com grande atividade respiratória. Em contraste, as mitocôndrias fragmentadas são frequentemente encontradas em células em repouso e/ou quando a alta atividade respiratória não é necessária. A fissão mitocondrial contribui para a manutenção da capacidade bioenergética, uma vez que permite a eliminação das mitocôndrias irreversivelmente danificadas por autofagia (CHAN, 2011; WESTERMANN, 2012; VAN DER BLIEK; SHEN; KAWAJIRI, 2013).

Sabe-se que uma dieta enriquecida com AGs omega-3 promovem alterações na dinâmica e na bioenergética mitocondrial (LIONETTI et al., 2013, 2014; PUTTI et al., 2015). Em 2014, SUN et al mostraram que a suplementação com óleo de peixe aumenta a expressão de proteínas de fusão mitocondrial como a Mfn-2 (mitofusina-2) e Opa1 e diminui a expressão de Fis 1 (fission-1) (SUN et al., 2014).

Os processos de fusão, fissão, biogênese e mitofagia devem ser todos coordenados, pois são importantes para a função bioenergética (CHEN, 2005; WESTERMANN, 2010). Os mecanismos de regulação devem ser capazes de induzir um amplo conjunto de genes mitocondriais e ao mesmo tempo permitir a expressão de genes específicos do tecido (HOCK; KRALLI, 2009).

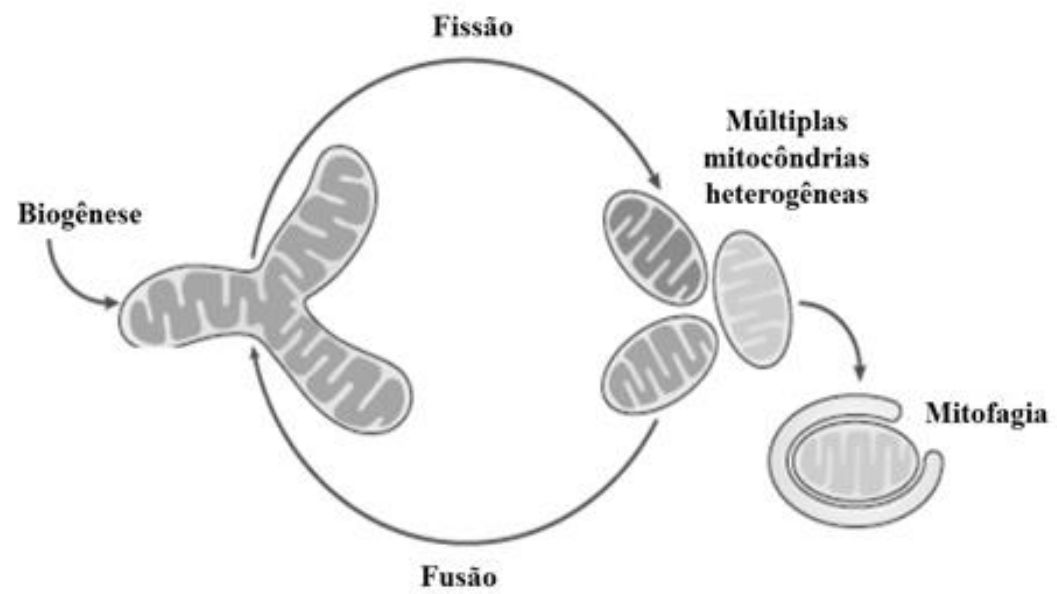

Figura 5: Ciclo de vida da mitocôndria. Durante o seu ciclo de vida, as mitocôndrias se fundem umas com as outras (fusão mitocondrial) e se separaram novamente (fissão mitocondrial) e as organelas danificadas são descartadas através da mitofagia. (Figura retirada e modificada de WESTERMANN, 2010).

A biogênese mitocondrial, em geral, é definida como um processo no qual as organelas aumentam sua densidade e dividem-se para dar origem a duas organelas idênticas (VALERO, 2014). No entanto é um processo complexo e requer numerosas etapas: além da síntese de proteínas codificadas pelo mtDNA e biogênese de novas estruturas organelares, também inclui 
a síntese e importação de proteínas codificadas nucleares e replicação do mtDNA (SCARPULLA, 2011; WENZ, 2013)

Uma proteína essencial no processo de biogênese é o co-ativador transcricional PGC$1 \alpha$ (peroxisome proliferator-activated receptor-gamma coactivator 1 alpha) que tem um importante papel na regulação dos genes envolvidos no metabolismo energético e da função mitocondrial, o que inclui termogênese, biogênese, metabolismo de glicose e ácidos graxos. É expresso em diversos tecidos, especialmente aqueles com alto metabolismo oxidativo como músculo esquelético, tecido adiposo marrom e cérebro (SPIEGELMAN; HEINRICH, 2004).

A proteína co-ativadora PGC-1 $\alpha$ recebeu este nome devido a interação com o PPAR $\gamma$ (Peroxisome proliferator-activated receptor), um grupo de proteínas receptoras nucleares que funcionam como fatores de transcrição que regulam a expressão dos genes relacionados ao metabolismo de ácidos graxos (GURNELL, 2003) pois foi identificada pela primeira vez no tecido adiposo marrom onde, durante a exposição ao frio causava aumento atividade transcricional PPAR $\gamma$ e aumento da expressão de UCP-1 (PUIGSERVER et al., 1998). PGC$1 \alpha$ também é altamente expresso no músculo esquelético nas fibras oxidativas tipo I (SPIEGELMAN; HEINRICH, 2004) e estimula a expressão de UCP-2 e UCP-3 (WU et al., 1999; PUIGSERVER et al., 2001) proporcionando uma base molecular para uma ligação entre estímulos ambientais/hormonais, biogênese e respiração mitocondrial quando o organismo é submetido a condições que promovam alterações em seus requisitos energéticos e/ou termogênicos (PUIGSERVER; SPIEGELMAN, 2003).

A biogênese e respiração mitocondrial são estimulados por PGC-1 $\alpha$ através do aumento de sua expressão devido a ativação de receptores adrenérgicos pelo sistema nervoso simpático quando este é estimulado por fatores hormonais ou ambientais. Esse aumento na expressão de PGC-1 $\alpha$ induz a expressão gênica dos fatores de transcrição nucleares de respiração 1 e 2 (NRF1 e NRF2), que agem como fatores de transcrição de alguns genes nucleares que codificam subunidades da CTE e da fosforilação oxidativa, e genes responsáveis pela replicação e transcrição do mtDNA. Além dos NRFs, o PGC-1 $\alpha$ também atua como coativador de outros fatores de transcrição como receptores relacionados ao estrógeno (ERRs), hormônios da tireóide e glicocorticóides, conhecidos por regular processos mitocondriais como $\beta$-oxidação de AGs e termogênese (Figura 6) (WU et al., 1999; NAKATANI et al., 2002; KELLY; SCARPULLA, 2004; LIANG; WARD, 2006; CLAPIER, V.; GARNIER, A.; VEKSLEY, 2008; HOCK; KRALLI, 2009). 


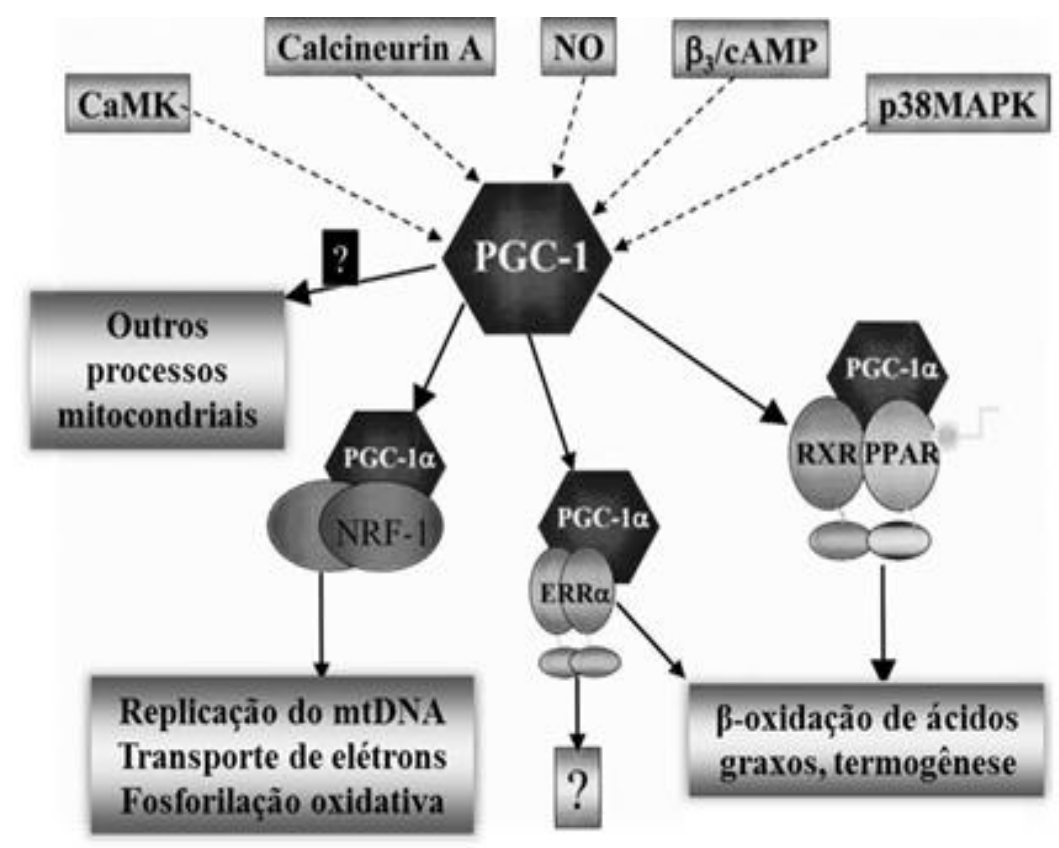

Figura 6: PGC-1 $\alpha$ atua como coativador de fatores de transcrição que desencadeiam processos mitocondriais (Figura retirada e modificada de KELLY; SCARPULLA, 2004).

\subsection{Estresse oxidativo}

Responsáveis pela respiração celular (fosforilação oxidativa) e manutenção da vida dos seres aeróbicos, as mitocôndrias também são as principais geradoras de radicais livres em células animais. Os radicais livres são espécies químicas altamente reativas à presença de um par de elétrons livres formados através de reações de óxido-redução no metabolismo aeróbico (FIGUEIRA et al., 2013). Essas espécies podem ser denominadas também como "espécies reativas de oxigênio" (EROs) e estão presentes no meio biológico. Em condições fisiológicas do metabolismo celular aeróbio, a redução completa do $\mathrm{O}_{2}$ ocorre na mitocôndria, e a reatividade das EROs é neutralizada com a entrada dos quatro elétrons, resultando na formação de água $\left(\mathrm{H}_{2} \mathrm{O}\right)$. Durante esse processo são formados intermediários reativos, como os radicais superóxido $\left(\mathrm{O}_{2}{ }^{\circ}\right)$, hidroperoxila $\left(\mathrm{HO}_{2}{ }^{\circ}\right)$, hidroxila $\left(\mathrm{OH}^{\bullet}\right)$ e o peróxido de hidrogênio $\left(\mathrm{H}_{2} \mathrm{O}_{2}\right)$ (FERREIRA,; MATSUBARA, 1997; BALABAN; NEMOTO; FINKEL, 2005). O $\mathrm{H}_{2} \mathrm{O}_{2}$, apesar de não ser um radical livre, por não ter um elétron desemparelhado na sua última camada eletrônica, é uma espécie com alto potencial reativo tem vida longa e é capaz de atravessar as membranas celulares apresentando-se potencialmente tóxico para as células (BARBOSA et al., 2010). 
Do total do oxigênio consumido pela CTE, 95 a $98 \%$ é utilizado como aceptor final de elétrons e cerca de 2 a $5 \%$ é gerado como um intermediário reduzido por um elétron formando um radical superóxido, o primeiro intermediário a ser formado na CTE (RIBEIRO et al., 2005). Os dois principais geradores do radical superóxido na CTE são o sítio da ubiquinona no complexo III (TURRENS; ALEXANDRE; LEHNINGER, 1985; CHEN et al., 2003) e grupo mononucleotideo de flavina (FMN) presente no complexo I (LIU; FISKUM; SCHUBERT, 2002; MURPHY, 2009) que, segundo LIU et al. (2002) é o local mais relevante do ponto de vista fisiológico e patológico na produção de EROs.

Em concentrações fisiológicas, as EROs têm funções de atuar como mensageiros intracelulares, mas em limiares supra fisiológicas, as EROs podem ser prejudiciais uma vez que devido a sua reatividade podem oxidar biomoléculas como proteínas, lipídeos, carboidratos e DNA (RIBEIRO et al., 2005). Para manter o equilíbrio entre as condições pró-oxidantes e antioxidantes o organismo apresenta mecanismos de defesas não enzimáticos e enzimáticos para conter os efeitos deletérios na produção excessiva das EROs.

O sistema de defesa não-enzimático inclui, especialmente, os compostos antioxidantes de origem dietética. Acredita-se que os ácidos graxos poliinsaturados possam funcionar como antioxidantes importantes principalmente para evitar a peroxidação de lipídeos de membranas, uma vez que as moléculas de lipídios, contendo maior número de duplas ligações, são mais susceptíveis a perda do hidrogênio para as EROs. Desta forma, estes AGs são capazes de minimizar e/ou impedir o ataque dos radicais livres a sistemas biológicos importantes como o sistema nervoso central (CARNEIRO et al., 2011).

No aspecto das enzimas antioxidantes responsáveis por manter o nível fisiológico de EROS, as principais são a superóxido dismutase (SOD), proteína presente no citosol e na mitocôndria, que catalisa a conversão do radical superóxido em peróxido de hidrogênio. Ainda estao presentes a glutationa peroxidase (GSH-Px) e a catalase que convertem $\mathrm{H}_{2} \mathrm{O}_{2}$ em $\mathrm{H}_{2} \mathrm{O}$ (BARBOSA et al., 2010). A glutationa reduzida (GSH) é o tiol (-SH) mais abundante no meio intracelular e pode ser considerada um dos agentes mais importantes do sistema de defesa antioxidante mitocondrial e celular, devido a sua capacidade redutora que é determinada pelo grupamento -SH, presente na cisteína. Na inativação de um agente oxidante ocorre produção de GSSG e depleção de GSH. Em situações em que o sistema de óxido-redução está íntegro, haverá recuperação da GSH. Entretanto, sob condições de excesso de agentes oxidantes e/ou deficiência do sistema protetor, haverá desequilíbrio entre o consumo de GSH e a produção de GSSG, o que caracteriza o estresse oxidativo (FERREIRA,; MATSUBARA, 1997). A 
manutenção de níveis adequados de GSH é feita as custas da atividade da glutationa redutase, a qual utiliza NADPH para manter a glutationa na forma reduzida como substrato para a glutationa peroxidase (Figura 7) (RIBEIRO et al., 2005).

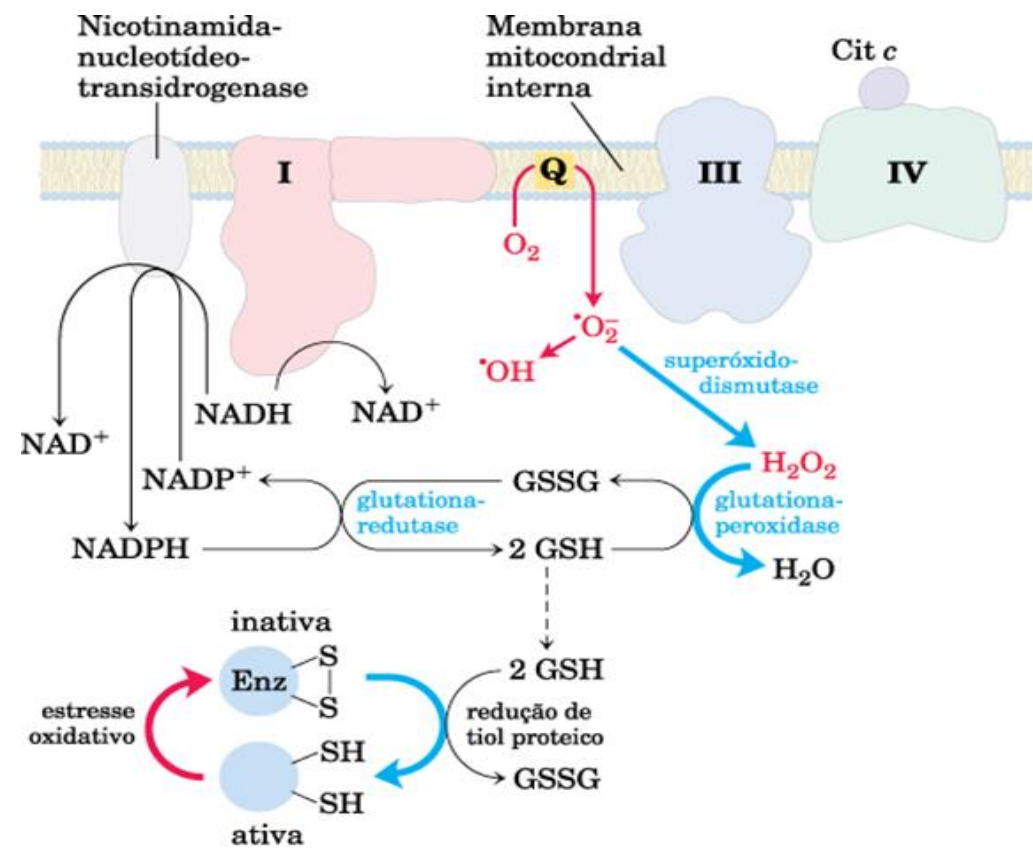

Figura 7: Formação de EROs nas mitocôndrias e sistema de defesa mitocondrial. Quando a taxa de entrada e a de transferência de elétrons na cadeia não são coordenadas, a produção do radical superóxido aumenta nos complexos I e III à medida que o radical ubiquinona parcialmente reduzido doa um elétron para o $\mathrm{O}_{2}{ }^{-}$. A enzima aconitase leva a formação do radical hidroxil $\left({ }^{\circ} \mathrm{OH}\right)$, fortemente reativo. A glutationa reduzida $(\mathrm{GSH})$ doa elétrons para a redução de $\mathrm{H}_{2} \mathrm{O}_{2}$ e dos resíduos oxidados de cisteína de enzimas e de outras proteínas. O GSH é regenerado a partir da forma oxidada (GSSG) por redução utilizando NADPH (Figura retirada de NELSON; COX, 2011).

\section{3. Ácidos graxos}

\section{1 Ácido linoleico conjugado (CLA)}

O ácido linoleico conjugado (CLA) é um conjunto de ácidos graxos $\omega-6$ produzidos naturalmente no rúmen do gado em um processo de fermentação do ácido linoleico pela bactéria Butyrivibrio fibrisolvens ou pela síntese via $\alpha 9$-dessaturase do ácido 11-trans octadecanóico, por isso o consumo de carne de ruminantes (bovinos e ovinos) e produtos lácteos (leite e queijo) é a principal fonte alimentar ao CLA (LEHNEN et al., 2015)

O CLA é uma mistura de isômeros posicionais e geométricos do ácido linoleico (C18:2, cis-9, cis-12) que envolve uma dupla ligação nas posições 8 e 10, 9 e 11 e, 10 e 12 ou 11 e 13. 
Em outras palavras, as ligações são conjugadas ao invés de existirem na configuração interrompida com um grupo metil. Cada um desses isômeros posicionais pode ocorrer em configurações cis-trans, trans-cis, cis-cis e trans-trans, mas somente os isômeros c9, t11 e t10, c12 demonstram efeitos biológicos, separados ou juntos (Figura 8). O CLA tem mostrado uma variedade de efeitos benéficos como anticancerígenos, anti-arterosclerose, antioxidante e antiobesidade. (AYDIN, 2005; MOURÃO et al., 2005; SANTOS-ZAGO; BOTELHO; DE OLIVEIRA, 2008; OLESZCZUK et al., 2012). No entanto, estudos tem demonstrado alguns efeitos desfavoráveis como aumento da resistência à insulina e fígado gorduroso (CLÉMENT et al., 2002; ZHOU et al., 2008; HALADE; RAHMAN; FERNANDES, 2009; ALMEIDA et al., 2015), embora estes efeitos sejam dependentes de tipo do isômeros, tempo de tratamento e concentração da dose administrada (MOURÃO et al., 2005; HALADE; RAHMAN; FERNANDES, 2009).

A presença de duplas ligações na configuração trans em isômeros do CLA contribui para a estabilidade do mesmo à oxidação, mas a literatura parece divergente quanto à relação CLA e estresse oxidativo. A concentração é uma variável fundamental para avaliar a ação do CLA. Em concentrações baixas, intermediárias e elevadas o CLA atua como pró-oxidante, antioxidante e pró-oxidante respectivamente, por isso o CLA é um agente pró-oxidante devido à observação do aumento do estresse oxidativo em concentrações baixas, quando se esperaria um efeito antioxidante (FLINTOFF-DYE; OMAYE, 2005; SANTOS-ZAGO; BOTELHO; DE OLIVEIRA, 2008). RISÉRUS et al., (2002) indica que os efeitos pro-oxidantes do CLA são isômeros específicos. Um trabalho publicado por nosso laboratório relatou que mitocôndrias isoladas do fígado de camundongos tratados com 2,2\% de CLA, quando energizadas com substrato respiratório de complexo I aumentavam a geração de EROS quando comparado ao controle, mas não ao ponto de causar dano hepático (PEREIRA et al., 2012). 
(A)

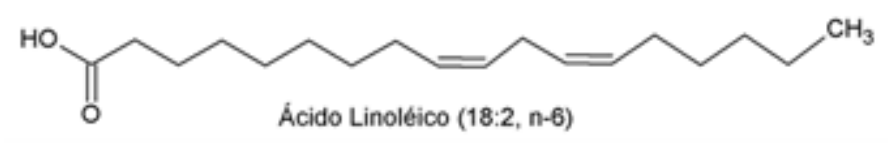

(B)

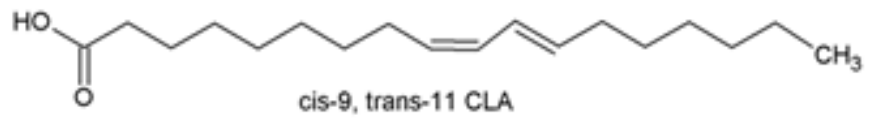

(C)

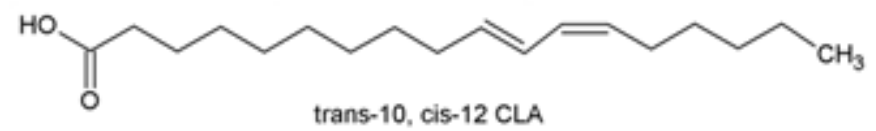

Figura 8: Estruturas químicas planares do (A) ácido linoleico (C18:2 c-9,c-12) e seus isômeros geométricos e posicionais. (B) CLA C:18 c-9, t-11 e (C) CLA C:18 c-10, c-12.

Inúmeros estudos em roedores são controversos quanto aos efeitos do CLA sobre o ganho de peso, mas a grande maioria dos trabalhos possuem observações consistentes quanto a redução na gordura corporal. Por exemplo, WEST et al. (1998) e AZAIN et al. (2000) trataram camundongos por 6-7 semanas com 1-1, 2\% de CLA. O primeiro estudo notou redução significativa no ganho de peso bem como aumento no gasto energético, ao passo que o segundo não observou diferenças na redução de peso, mas ambos encontraram redução da adiposidade. AZAIN et al., (2000) ainda demonstrou que o CLA não promove redução no número de adipócitos mas sim no tamanho das células, propriedade que vem sendo observada em muitos trabalhos in vivo (PARIZA, 2004; PARK; PARIZA, 2007) e in vitro (EVANS et al., 2000; BROWN; EVANS; MCINTOSH, 2001)

O CLA tem sido estudado pela sua capacidade de reduzir a adiposidade através do aumento do gasto energético por elevar a taxa metabólica basal, termogênese e oxidação lipídica em animais (WEST et al., 2000; OHNUKI et al., 2001; KOBA et al., 2002), no entanto os mecanismos para explicar os efeitos do CLA ainda não são bem compreendidos. Uma das hipóteses sugere a modulação da expressão gênica exercida por esse ácido graxo conjugado, mediada pela ativação ou inibição de PPARs, em especial o PPAR $\gamma$ (SANTOS-ZAGO; BOTELHO; DE OLIVEIRA, 2008), que por sua vez que induz a expressão gênica das UCPs. Trabalhos em nosso laboratório demonstraram aumento do metabolismo corporal via expressão da UCP2 no fígado como resultado do tratamento com CLA (PEREIRA et al., 2012; BARALDI et al., 2016), o que é relacionado ao efeito termogênico deste AG. Foi relatado também por KOBA et al., (2002) que o CLA é capaz de aumentar a $\beta$-oxidação através do aumento da 
atividade da carnitina palmitoil transferase II (CPT-II) um enzima essencial para o transporte de AGs para o interior da mitocôndria.

Estudos recentes têm mostrado que o CLA também é capaz de conduzir a biogênese mitocondrial. O trabalho publicado por KIM e PARK em 2015 mostra que, em células C2C12 os isômeros cis-9,trans-11 (c9,t11) e trans-10,cis-12 (t10,c12) do CLA promovem biogênese mitocondrial através do aumento da expressão de PGC1 $\alpha$, NRF-1 e do número de cópias do mtDNA. Um ano antes, MOLLICA et al., (2014) demonstraram que doses dietéticas do isômero c9,t11 aumentam a taxa GSH/GSSG no fígado, funções mitocondriais e atividade de NRF-2 e por isso também sugerem a biogênese mitocondrial induzida por CLA.

\section{2 Óleo de peixe}

Os ácidos graxos poli-insaturados (PUFAs) da família ômega 3 ( $\omega$-3) são AG de cadeia muito longa e os principais representantes dessa família são os AGs $\alpha$-linolênico (ALA C18:3), ácido eicosapentaenóico (EPA - C20:5) e ácido docosahexaenóico (DHA- C22:6). São componentes das membranas celulares, sendo também precursores de substâncias, como as prostaglandinas, tromboxanos e leucotrienos (NOVELLO; FRANCESCHINI; QUINTILIANO, 2008). O EPA e o DHA são predominantemente encontrados em peixes de água salgada como salmão, atum e sardinha e dessa forma são os maiores constituintes do óleo de peixe. Sua síntese a partir do ácido $\alpha$-linolênico ocorre em pouquíssimas quantidades no organismo e por isso são classificados como AG essenciais e devem ser obtidos através da alimentação (HULL, 2011). Eles se diferenciam dos AGs $\omega-6$ na posição em que a dupla ligação está no terceiro carbono a partir da extremidade oposta à carboxila (Figura 9). O número e a posição das duplas ligações determinam as propriedades físicas e químicas dos PUFAs (NELSON; COX, 2014). 
(A)

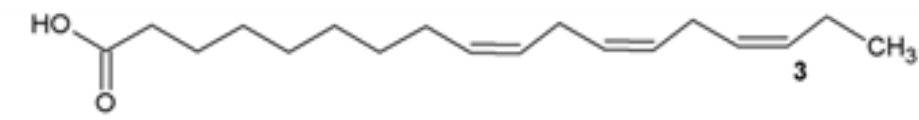

Ácido $\alpha$ Linolénico (ALA, C18:3, Ômega 3)

(B)

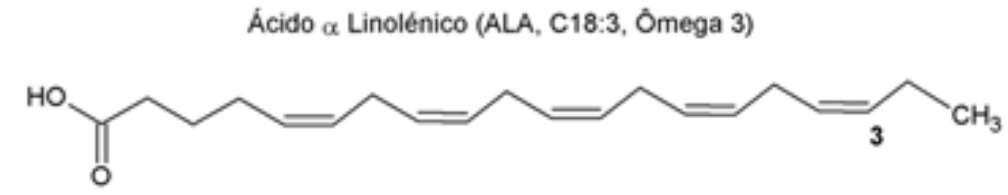

Ácido eicosapentanóico (EPA, C20:5, ômega 3)

(C)

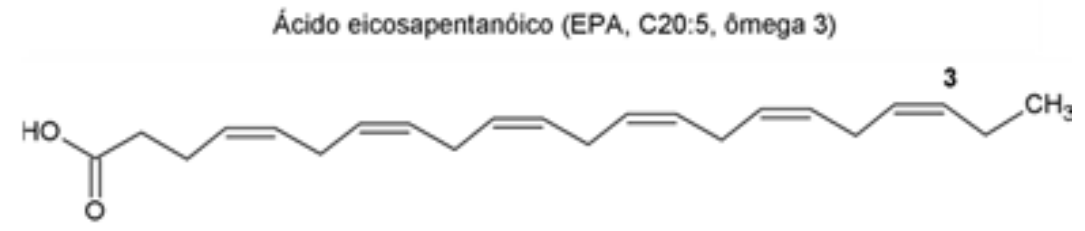

Ácido docosahexanóico (DHA, C22:6, Ômega 3)

Figura 9: Estruturas químicas planares dos ácidos graxos $\omega-3$ mais importantes. (A) ácido $\alpha$ linolênico (C18:3), (B) Ácido eicosapentanóico (EPA, C20:5) e (C) Ácido docosahexanóico (C22:6).

Os estudos com AG $\omega$-3 foram iniciados por DYERBERG et al na década de 70. Seus estudos demonstraram que populações de esquimós da Groenlândia que consumiam peixes com alto conteúdo de $\omega-3$ apresentavam uma incidência mais baixa de morte por doenças cardiovasculares (DYERBERG; BANG; HJORNE, 1975; BANG; DYERBERG; HJOORNE, 1976) . Também tem sido relatado efeitos anticancerígenos (CARMO; CORREIA, 2009), antiinflamatórios (L.M., 2003; DA LUZ et al., 2012), contra hipertrigliceridemia (diminuindo os níveis de triacilglicerois e aumentando os níveis de HDL) (SHEARER; SAVINOVA; HARRIS, 2012; WEINTRAUB, 2014), doenças cardiovasculares (SARAVANAN et al., 2010; LORENTE-CEBRIÁN et al., 2013) e resistência à insulina (DA LUZ et al., 2012; HIRABARA et al., 2013). Os AGs do óleo de peixe parecem atuar de forma muito eficiente sobre o sistema nervoso com benefícios sobre o comportamento (DEMAR et al., 2006; RE; ZANOLETTI; EMANUELE, 2008; LIN; HUANG; SU, 2010), memória (RICHTER et al., 2010) e doenças neuronais como o Alzheimer (MORRIS et al., 2003). Devido aos inúmeros efeitos positivos destes PUFAs, eles atraíram a atenção da comunidade científica e permanecem como cobiçado objeto de estudo.

A literatura tem mostrado trabalhos que relacionam os AGs $\omega-3$ com a modulação direta do metabolismo. Em um trabalho publicado recentemente mostra que o tratamento óleo de peixe aumenta a função mitocondrial e diminui a produção de ROS. Ainda os autores observaram in vivo e in vitro a fusão de mitocondrial e relacionam a dinâmica e função diretamente com a dieta com óleo de peixe. (LIONETTI et al., 2014). 
EPA e DHA atuam modulando a expressão de vários genes relacionados ao metabolismo (JUMP, D. B., TRIPATHY, S.; DEPNER, 2013). No musculo esquelético estimula o transporte de glicose e induz a biogênese mitocondrial através da ativação do NRF1 e de PGC-1 $\alpha$ (FLACHS et al., 2009). No fígado, parte dos efeitos metabólicos dos AGs $\omega-3$ são mediados pela estimulação da AMPK (SUCHANKOVA et al., 2005), que por sua vez inibe a lipogênese e a gliconeogênese enquanto estimula a $\beta$-oxidação. Também no fígado BELZUNG et al. (1993) observaram que o óleo de peixe aumenta a glicólise e a glicogênese e aumenta a sensibilidada à insulina, assim como JING LUO et al. (1996) observaram o mesmo efeito em ratos resistentes à insulina. De acordo com HIRABARA et al., (2013) os efeitos insulínicos do tratamento com óleo de peixe ainda permanecem ativos e otimizado por duas gerações de ratos. Tanto no tecido adiposo epididimal e dorsolombar de camundongos C57BL6 quanto em células 3T3-L1 tratados com DHA foram observados aumento de PGC-1 $\alpha$ e Nrf1, mostrando a regulação da biogênese mitocondrial por esse ácido graxo (FLACHS et al., 2005). Ainda em células 3T3-L1, GUO et al. (2005) mostrou que o EPA aumenta a $\beta$-oxidação através do aumento da atividade de CPT-I que é uma enzima essencial para a entrada de AGs na mitocôndria. A expressão mitocondrial de CPT-I é regulada upstream pelos PPARs e pela AMPK. Este último ativado por EPA tanto no tecido adiposo (LORENTE-CEBRIÁN et al., 2009) quanto no músculo esquelético (MOTAWI et al., 2009). Por sua vez, os PPARs estão diretamente ligados aos mecanismos de ação dos AGs $\omega$-3 (SUN; WEI; LI, 2011). Em ratos e em camundongos foi relatado que a dieta com óleo de peixe aumenta a expressão de PPAR $\alpha$ no fígado (TAKAHASHI et al., 2002; LIONETTI et al., 2014) e que altas doses de DHA aumentam a expressão de PPAR $\gamma$ no tecido adiposo (SUN; WEI; LI, 2011). Ativadores de PPARs podem estimular a expressão de UCPs. BAILLIE et al., (1999) mostram que a suplementação com óleo de peixe aumenta a expressão de UCP3 no músculo esquelético, e UCP2 no fígado e coração. Da mesma forma TSUBOYAMA-KASAOKA et al., (1999) mostrou o aumento da expressão de UCP1, UCP2 e UCP3 no tecido adiposo marrom, no fígado e no gastrocnêmio respectivamente em camundongos tratados com óleo de peixe. 


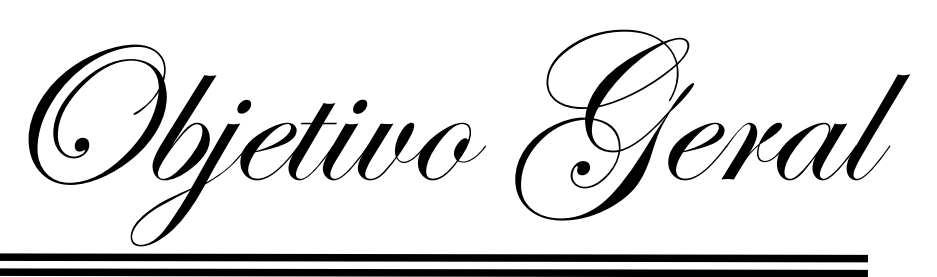




\section{OBJETIVO GERAL}

O objetivo do estudo foi verificar os efeitos da suplementação da dieta com CLA, um potente ativador do metabolismo corporal via expressão de UCP2, em conjunto ao óleo de peixe, um estimulador da biogênese mitocondrial, sobre aspectos da bioenergética mitocondrial, bioquímicos, moleculares e fisiológicos do metabolismo corporal. Analisamos também se as propriedades antioxidantes dos óleos de peixe atenuariam o estresse oxidativo induzido por CLA. 


\section{Materiais e Metodos}




\section{MATERIAIS E MÉTODOS}

\section{Animais e protocolo experimental}

Camundongos machos da linhagem C57BL6 de cinco semanas de idade foram adquiridos do Biotério Central da Universidade de São Paulo no campus de Ribeirão Preto e mantidos em caixas padrão $(33 \times 23 \times 12 \mathrm{~cm})$ em condições de luz $(12 \mathrm{~h})$ e temperatura $\left(23^{\circ} \mathrm{C}\right)$ controladas. Os animais tiveram acesso ad libitum à água filtrada e ração industrial contendo $22 \%$ de proteínas, $40 \%$ de carboidratos e $4 \%$ de gordura. Após uma semana de adaptação ao ambiente, os camundongos $(\mathrm{n}=20)$ foram divididos em 4 grupos com 5 animais cada (Figura 10).

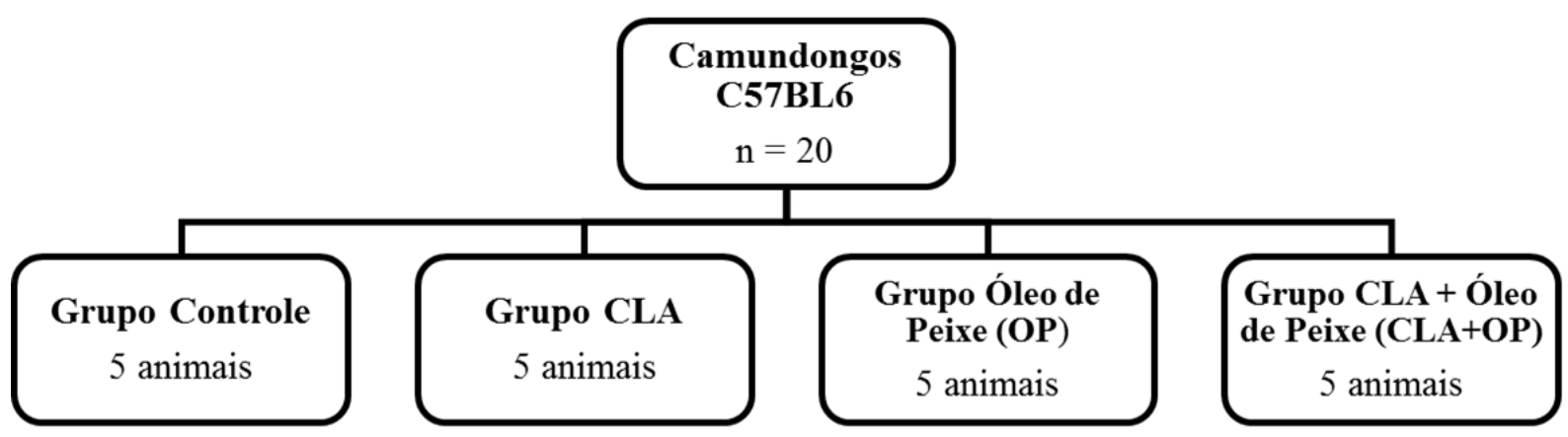

Figura 10: Divisão dos animais em grupos experimentais: Controle, CLA, óleo de Peixe (OP) e CLA + óleo de peixe (CLA + OP).

O grupo controle foi suplementado com $0,1 \mathrm{~mL}$ de ácido linoleico comercial MAZOLA $^{\circledR}$; o grupo CLA (GNC PRO PERFORMANCE ${ }^{\circledR}$ ) recebia $0,1 \mathrm{~mL}$ de ácido linoleico e 0,1mL de ácido linoleico conjugado (mistura de 1:1 dos isômeros 18:2 cis-9, trans-11e trans10, cis-12); o grupo óleo de peixe (OP) foi suplementado com $0,1 \mathrm{~mL}$ de ácido linoleico e $0,1 \mathrm{~mL}$ de óleo de peixe comercial Ocean Blue ${ }^{\circledR}$ OmegaPower ${ }^{\mathrm{TM}}$ composto por EPA e DHA na proporção de 2:1 e, por fim, o grupo CLA + óleo de peixe (CLA + OP) tratado com 0,1mL de óleo de peixe e $0,1 \mathrm{~mL}$ de ácido linoleico conjugado. Os grupos que foram tratados com dois óleos, os recebiam em dias alternados (Tabela 1). Todas as suplementações foram realizadas por via oral durante 60 dias e o peso de cada animal foi monitorado semanalmente. Cada tratamento foi realizado por 3 vezes, totalizando 15 animais por grupo. O protocolo experimental foi aprovado pela Comissão de Ética no Uso de Animais (CEUA), protocolo experimental $n^{\circ}$ 14.1.239.53.0. 
Tabela 1: Periodização da suplementação dos quatro grupos experimentais com seus respectivos ácidos graxos. A suplementação foi feita durante um período de 60 dias.

\begin{tabular}{ccccc}
\hline Dia / Grupo & Controle & CLA & OP & CLA + OP \\
\hline Segunda-feira & Ácido linoleico & CLA & Ácido linoleico & CLA \\
Terça-feira & Ácido linoleico & Ácido linoleico & Óleo de peixe & Óleo de peixe \\
Quarta-feira & Ácido linoleico & CLA & Ácido linoleico & CLA \\
Quinta-feira & Ácido linoleico & Ácido linoleico & Óleo de peixe & Óleo de peixe \\
Sexta-feira & Ácido linoleico & CLA & Ácido linoleico & CLA \\
& & & & \\
\hline
\end{tabular}

\section{Calorimetria indireta}

Após 30 dias de suplementação o metabolismo corporal in vivo dos camundongos foi analisado através de calorimetria indireta utilizando o calorímetro Sistema Oxylet Panlab ${ }^{\circledR} /$ Harvard Apparatus, Espanha. Foram utilizadas 4 caixas de acrílico $(29,4$ x 29 x $32 \mathrm{~cm})$ simultaneamente; cada uma representando um grupo contendo um camundongo por caixa. Todos os animais de cada grupo foram submetidos ao mesmo monitoramento com duração de 24 horas. As caixas foram alternadas aleatoriamente para minimizar o erro experimental. $\mathrm{O}$ metabolismo foi mensurado por meio das variáveis: volume de oxigênio consumido $\left(\mathrm{VO}_{2}\right)$; volume do gás carbônico produzido $\left(\mathrm{VCO}_{2}\right)$, coeficiente respiratório (RQ) que é uma relação entre $\mathrm{VCO}_{2} / \mathrm{VO}_{2}$ e gasto energético total (EE), sendo este calculado ela equação:

$$
\mathrm{EE}=(3,85+(1,232 \times \mathrm{RQ})) \times \mathrm{VO}_{2} \times 1,44 .
$$

\section{Movimentação espontânea}

Utilizando o mesmo calorímetro Sistema Oxylet Panlab ${ }^{\circledR} /$ Harvard Apparatus e posteriormente 30 dias de suplementação, foi monitorado também as medidas de atividade horizontal (locomoção) e vertical (levantamento). Foram utilizadas duas caixas metabólicas apoiadas sobre uma plataforma que detectava a movimentação horizontal nos eixos direitaesquerda e frente-trás (figura 11A). Ao redor da caixa encontra-se 2 fotosensores que registram a movimentação do animal no eixo vertical (Figura 11B). Em cada caixa foram inseridos três camundongos de cada grupo durante 24 horas que recebiam ad libitum água filtrada e ração industrial. 
(A)

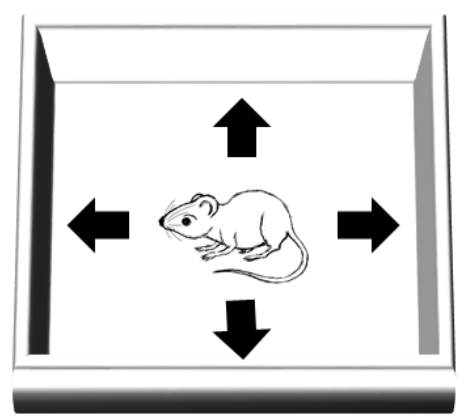

(B)

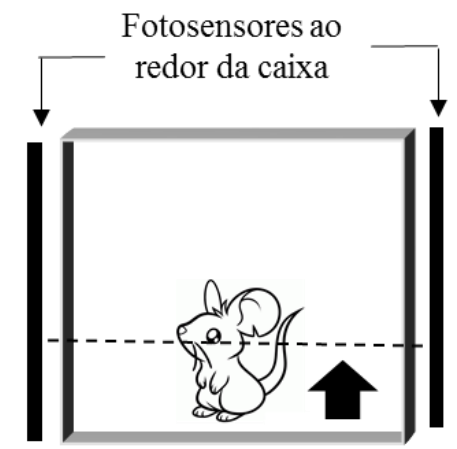

Figura 11: Esquemas mostrando a (A) detecção da movimentação horizontal e (B) detecção da movimentação vertical.

\section{Teste de tolerância a glicose (TTG)}

Após 40 dias de suplementação, os camundongos foram submetidos a 12 horas de jejum para realização do teste de tolerância a glicose (TTG). O teste de tolerância a glicose avalia a situação de uma carga de glicose administrada via oral, intraperitoneal ou intravenosa (AYALA et al., 2010) . Inicialmente foi feito um pequeno corte na extremidade da cauda de cada animal e, utilizando um glicosímetro de fita (OneTouch ${ }^{\circledR}$ Ultra $^{\circledR}$, Johnson \& Johnson Company, EUA) mensuramos a glicemia basal, determinando o tempo zero. Posteriormente cada camundongo um recebeu via oral uma dose contendo $1,5 \mathrm{~g} / \mathrm{Kg}$ de glicose (MEI; YU; AHRÉN, 2010). A glicemia foi verificada a cada 15 minutos por 2 horas.

\section{Teste de tolerância a insulina (TTI)}

O teste de tolerância a insulina (TTI) foi realizado após 50 dias de suplemenração. Os camundongos foram mantidos em estado de jejum por 8 horas. Posteriormente, sangue foi retirado da veia caudal através de um corte na extremidade da cauda do animal, e utilizou-se o glicosímetro de fita OneTouch ${ }^{\circledR}$ Ultra $^{\circledR}$, Johnson \& Johnson Company, EUA para as medidas de glicemia basal (tempo zero) e após a aplicação de insulina. A solução de insulina (Apidra ${ }^{\circledR}$ 100UI/mL, Sanofi Aventis Farmacêutica LTDA) foi aplicada via intraperitoneal (IP) de forma que cada animal recebesse $0,25 \mathrm{UI} / \mathrm{Kg}$ sendo a glicemia medida após 20 minutos da aplicação. Ao final do teste foi administrada uma dose de $20 \mathrm{uL}$ de solução de glicose $0,6 \mathrm{~g} / \mathrm{mL}$ e disponibilizado água e ração ad libitum aos camundongos. A taxa de decaimento da glicose plasmática $\left(K_{i t t}\right)$ foi calculada através da razão $0,693 / t_{1 / 2}$., no qual o $t_{1 / 2}$ da glicose foi calculada 
a partir da curva de análise dos mínimos quadrados da concentração de glicose durante a fase de decaimento linear (HIRABARA et al., 2013).

\section{Determinação da concentração plasmática de lipídeos}

Os testes de dosagem plasmática de triglicérides, colesterol HDL e colesterol total foram realizados com amostras de sangue, condicionadas em jejum de 12 horas, que foram retiradas extremidade da cauda dos camundongos por meio de um capilar heparizinado. As amostras foram imediatamente centrifugadas a 5300g (rotor F 45-30-11, Eppendorf $5810 \mathrm{R}$ ) por 10 minutos a $4^{\circ} \mathrm{C}$. As dosagens foram feitas utilizando o plasma e os kits para diagnóstico adquiridos da empresa Labtest Diagnóstica ${ }^{\circledR}$ S.A, Brasil. O procedimento foi realizado de acordo com as instruções do manual do fabricante.

\section{Eutanásia e extração de tecidos}

Após dois meses de tratamento, os camundongos foram previamente anestesiados por $\mathrm{CO}_{2}$ e sacrificados por deslocamento cervical, de acordo com as diretrizes da prática de eutanásia do CONCEA de 2013. O óbito foi confirmado através da ausência de movimentos torácicos e sinais de respiração, pupila dilatada, globo ocular fixo, insensibilidade nas extremidades dos membros e falta de batimentos cardíacos. Em seguida os animais foram pesados e o fígado, o cérebro, os músculos sóleos, o tecido adiposo marrom (TAM) interescapular e o tecido adiposo branco (TAB) perigonadal e perirenal e foram rapidamente retirados e pesados.

Os tecidos adiposos marrom e branco, o músculo sóleo esquerdo, pequena parte do fígado e do hipocampo foram imediatamente congelados em nitrogênio líquido e armazenados em biofreezer a $-80^{\circ} \mathrm{C}$.

O músculo sóleo direito, pequenos pedaços do fígado e do hipocampo foram utilizados para consumo de oxigênio de fatias de tecidos. $\mathrm{O}$ restante do tecido hepático foi utilizado para isolamento das mitocôndrias.

\section{Isolamento das mitocôndrias hepáticas}

As mitocôndrias de fígado foram isoladas por centrifugação diferencial de acordo com ALBERICI et al., 2006. Primeiramente a homogeneização do tecido foi realizada com o fígado lavado e picotado em $25 \mathrm{~mL}$ de tampão de isolamento gelado (entre 0 e $4^{\circ} \mathrm{C}$ ) contendo 250 
$\mu \mathrm{g} / \mathrm{mL}$ de sacarose, $1 \mu \mathrm{g} / \mathrm{mL}$ de EGTA, BSA 0,15\% e $10 \mu \mathrm{g} / \mathrm{mL}$ de HEPES-KOH, pH 7,2. Ainda o tecido foi homogeneizado em $25 \mathrm{~mL}$ de meio de isolamento, em gelo, utilizando o homogeneizador de tecidos Potter-Elvehjem, munido de um pistão de teflon a $140 \mathrm{rpm}$ em 3 ciclos de 15 segundos com intervalo de 1 minuto (Figura 12A).

Em seguida a etapa de centrifugação diferencial foi iniciada com o homogenato transferido para um tubo e centrifugado a $600 \mathrm{~g}$ por 10 minutos (rotor Hitachi RT15A5) a $4^{\circ} \mathrm{C}$. A camada lipídica flutuante foi retirada com pipeta Pasteur e o sobrenadante transferido para outro tubo, o qual foi centrifugado a $7000 \mathrm{~g}$ por mais 10 minutos a $4^{\circ} \mathrm{C}$. O sobrenadante foi descartado e com ajuda de um pincel, o pellet foi delicadamente ressuspendido em $10 \mathrm{~mL}$ de meio de lavagem composto de $250 \mu \mathrm{g} / \mathrm{mL}$ de sacarose, $0,1 \mu \mathrm{g} / \mathrm{mL}$ de EGTA e $10 \mu \mathrm{g} / \mathrm{mL}$ de HEPES-KOH, pH 7,2. A solução formada novamente centrifugada como citado anteriormente. Por fim, a fração mitocondrial foi resuspendida em $200 \mu \mathrm{L}$ de meio constituído por $250 \mu \mathrm{g} / \mathrm{mL}$ de sacarose e $10 \mu \mathrm{g} / \mathrm{mL}$ de HEPES-KOH, pH 7,2 (Figura 12B).

A. Homogeneização do tecido

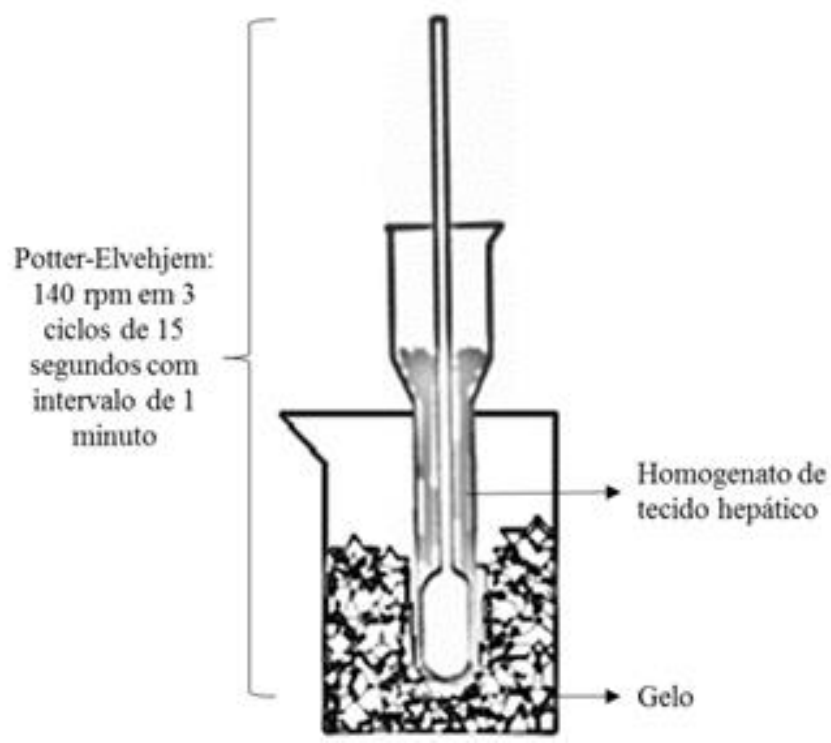


B. Centrifugação diferencial
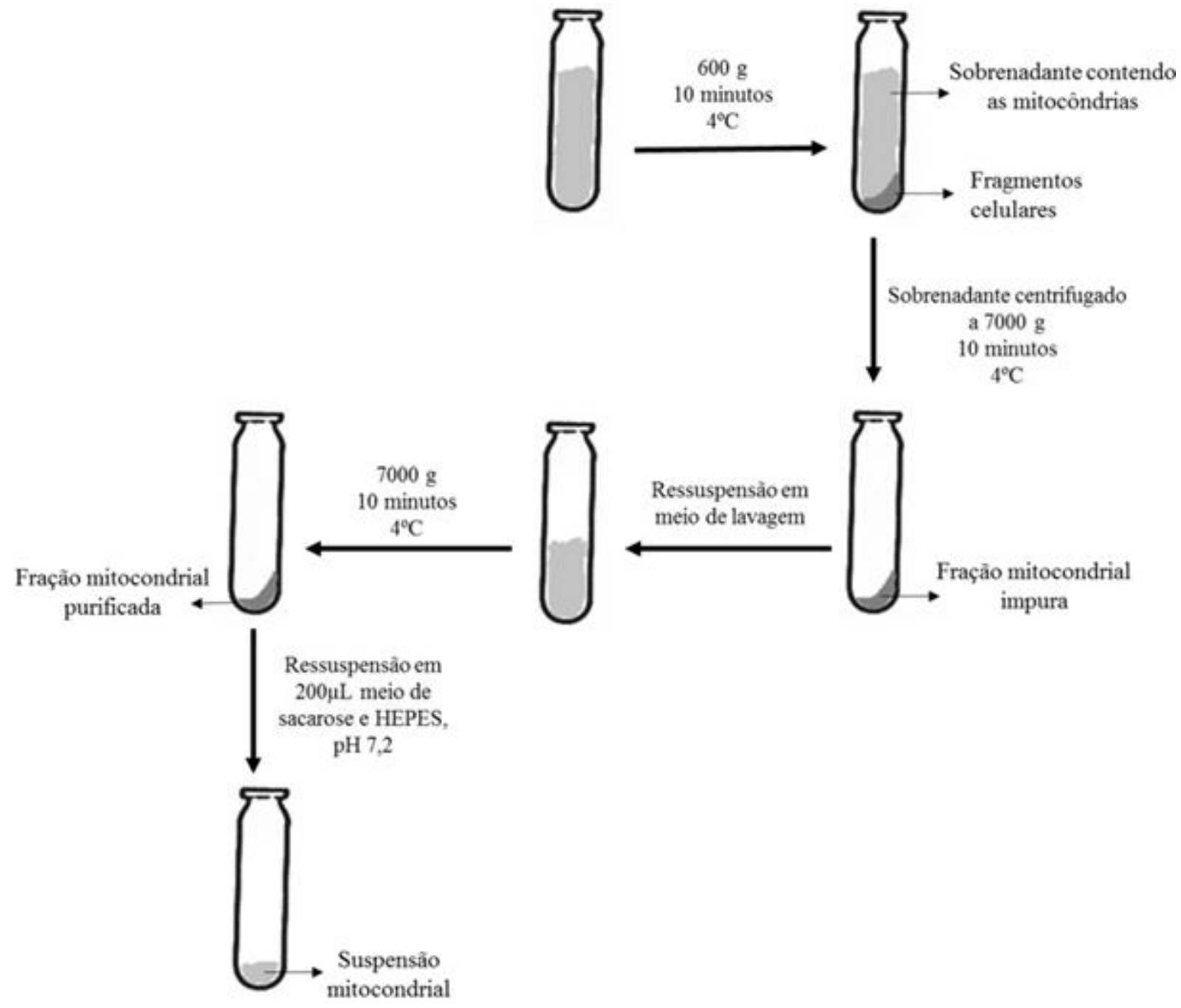

Figura 12: Representação esquemática do processo de isolamento de mitocôndrias pelo método de centrifugação diferencial.

\section{Determinação de proteínas}

A determinação de proteínas da suspensão mitocondrial foi feita empregando o método colorimétrico do Biureto, que é baseado na reação das ligações peptídicas com o íon cúprico em soluções alcalinas formando um produto de cor violeta.

Para solubilizar a membrana mitocondrial e liberar as proteínas internas utilizou-se o ácido cólico 5\%, sendo o BSA 1\% a proteína padrão. Em todos os tubos de ensaio foi adicionado 1,5 mL de Biureto e completou-se com água até $3 \mathrm{~mL}$. Após breve agitação, a leitura foi 
realizada por espectrofotometria a $540 \mathrm{~nm}$ em cubeta de plástico e os volumes de cada reagente estão indicados na Tabela 2

Tabela 2: Volumes de cada reagente utilizado para a dosagem de proteínas através do método colorimétrico do Biureto.

\begin{tabular}{cccccc}
\hline Tubos & Ácido cólico 5\% & BSA 1\% & $\begin{array}{c}\text { Suspensão } \\
\text { mitocondrial }\end{array}$ & Água & Biureto \\
\hline Branco & $100 \mu \mathrm{L}$ & ----------- & $---------------~$ & $1,4 \mathrm{~mL}$ & $1,5 \mathrm{~mL}$ \\
Padrão & $100 \mu \mathrm{L}$ & $100 \mu \mathrm{L}$ & --------------- & $1,3 \mathrm{~mL}$ & $1,5 \mathrm{~mL}$ \\
Amostra & $100 \mu \mathrm{L}$ & ----------- & $10 \mu \mathrm{L}$ & $1,390 \mathrm{~mL}$ & $1,5 \mathrm{~mL}$ \\
\hline
\end{tabular}

O procedimento para cálculo das proteínas totais foi feito da seguinte forma:

Proteínas totais $(\mathrm{mg} / \mathrm{mL})=$ Absorbância da amostra $\mathrm{x} 100$

Absorbância do padrão

Após o isolamento, as mitocôndrias foram utilizadas em procedimentos experimentais em um prazo máximo de 3 horas.

\section{Ensaios utilizando as mitocôndrias hepáticas isoladas}

\subsection{Composição do meio de respiração utilizado para os ensaios}

Para todos os ensaios com mitocôndrias isoladas de fígado foi utilizado o meio de respiração composto por $125 \mu \mathrm{g} / \mathrm{mL}$ de sacarose; $65 \mu \mathrm{g} / \mathrm{mL}$ de $\mathrm{KCl} ; 10 \mu \mathrm{g} / \mathrm{mL}$ de HEPES$\mathrm{KOH} \mathrm{pH} 7,2$. Posteriormente, no momento do uso, foi adicionado $2 \mu \mathrm{g} / \mathrm{mL}$ de fosfato inorgânico; $1 \mu \mathrm{g} / \mathrm{mL}$ de magnésio e $0,1 \mu \mathrm{g} / \mathrm{mL}$ de EGTA.

\subsection{Determinação do consumo de oxigênio das mitocôndrias isoladas de fígado}

O consumo de oxigênio foi analisado no eletrodo do tipo oxygraph-2k (Oroboros Instruments - High Resolution Respirometry) equipado com agitação magnética (200 rpm) e câmara termostatizada a $30^{\circ} \mathrm{C}$. Na câmara do oxígrafo foi adicionado $2 \mathrm{~mL}$ de meio respiração e $0,5 \mathrm{mg} / \mathrm{mL}$ de proteína mitocondrial. Após o fechamento da câmara foi adicionado $5 \mu \mathrm{g} / \mathrm{mL}$ de malato/glutamato $(2,5 \mu \mathrm{g} / \mathrm{mL}$ cada) e $5 \mu \mathrm{g} / \mathrm{mL}$ de succinato, como substratos respiratórios de complexo I e II, respectivamente. Além disso, para avaliar a atividade das UCPs foi 
adicionado $0,2 \mu \mathrm{M}$ de ácido linoleico (LA), um ácido graxo utilizado como substrato para estas proteínas.

A fim de iniciar e determinar o estado de fosforilação (estado respiratório 3) foi adicionado $200 \mathrm{nmol}$ de ADP/mg de proteína. O estado de repouso (estado respiratório 4) foi determinado após o consumo de todo ADP e o controle respiratório (CR) foi definido pela razão da velocidade respiratória no estado 3 pela velocidade respiratória obtida no estado 4 . A razão ADP/O foi calculada a partir da quantidade de ADP adicionada pela quantidade de oxigênio consumido no estado de fosforilação (Figura 13A e 13B).

(A)

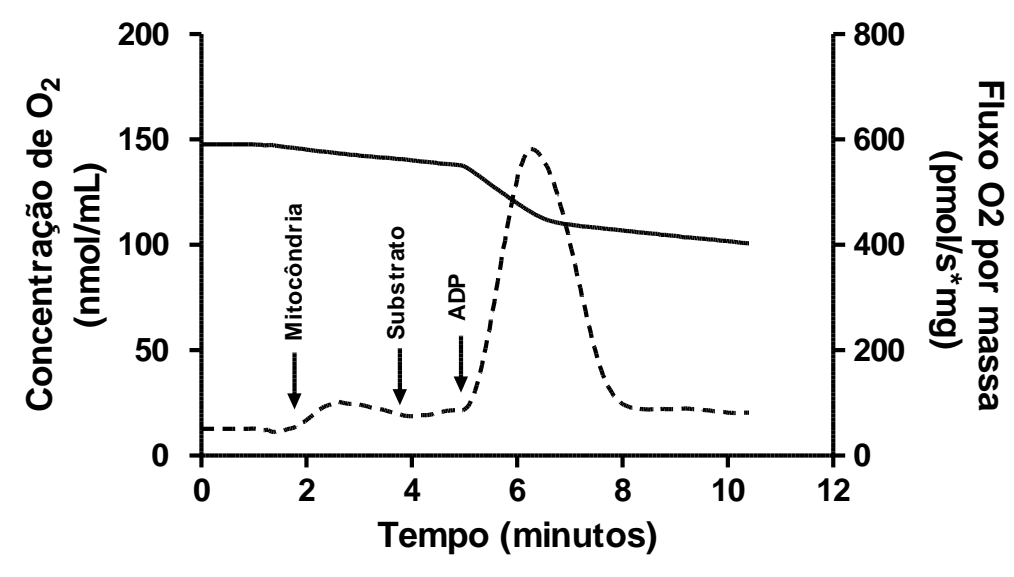

(B)

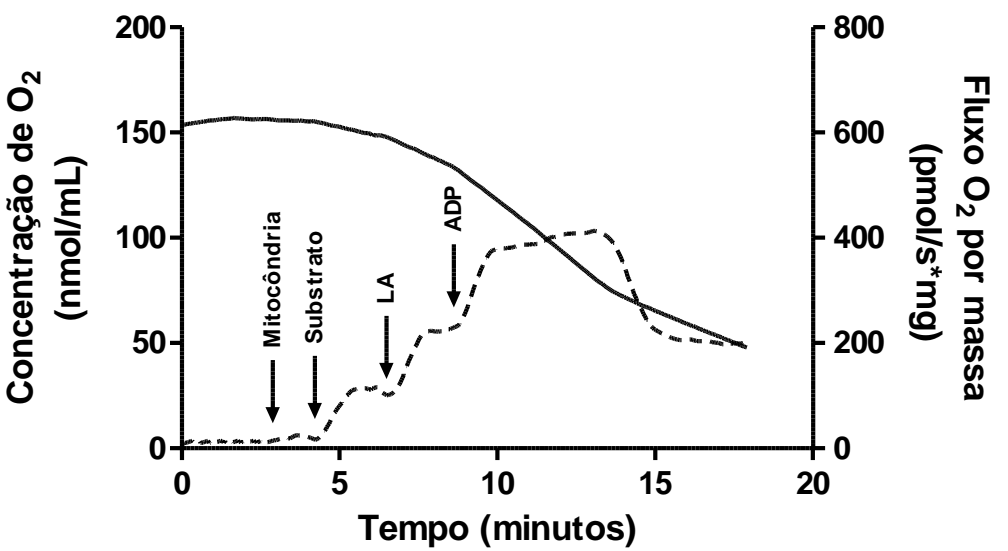

- -. Fluxo $\mathrm{O}_{2}$ por massa (pmol/s*mg)

- Concentração de $\mathrm{O}_{2}(\mathrm{nmol} / \mathrm{mL})$

Figura 13: Sequência das adições dos compostos durante o ensaio para a determinação do consumo de oxigênio nas mitocôndrias isoladas. Em (A) o ensaio na ausência de LA e em (B) na presença de LA. 


\section{$10.3 \beta$-oxidação}

Semelhante ao ensaio de consumo de oxigênio, o de $\beta$-oxidação também foi conduzido no eletrodo do tipo oxygraph-2k (Oroboros Instruments - High Resolution Respirometry) com agitação magnética $(200 \mathrm{rpm})$, a $30^{\circ} \mathrm{C}, \operatorname{com} 2 \mathrm{~mL}$ de meio de respiração e $0,5 \mathrm{mg} / \mathrm{mL}$ de proteína mitocondrial. Os substratos utilizados para averiguar a $\beta$-oxidação foram: $1 \mu \mathrm{M}$ de carbonil cianeto m-clorofenilhidrazona (CCCP), $1 \mu \mathrm{g} / \mathrm{mL}$ de malato; $15 \mu \mathrm{M}$ de palmitoil carnitina, $4,5 \mu \mathrm{g} / \mathrm{mL}$ de glutamato, $1 \mu \mathrm{M}$ de rotenona e $5 \mu \mathrm{g} / \mathrm{mL}$ de succinato (Figura 14).

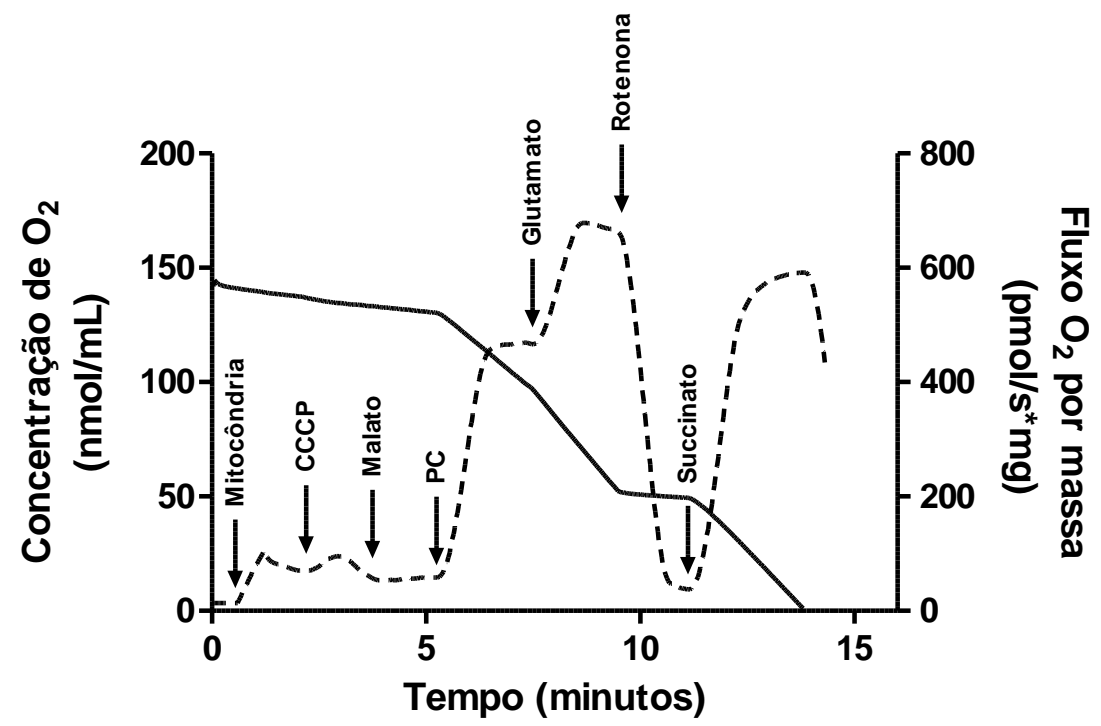

\section{- -. Fluxo $\mathrm{O}_{2}$ por massa (pmol/s*mg) \\ - Concentração de $\mathrm{O}_{2}(\mathrm{nmol} / \mathrm{mL})$}

Figura 14: Sequência das adições dos compostos durante o ensaio para a determinação da $\beta$ oxidação nas mitocôndrias isoladas.

\subsection{Produção de espécies reativas de oxigênio (EROs) mitocondrial}

A produção de espécies reativas de oxigênio foi monitorada espectrofluorimetricamente (Hitachi F-4500) sob agitação e utilizando $0,5 \mathrm{mg} / \mathrm{mL}$ de proteína mitocondrial. A determinação foi feita utilizando $2 \mathrm{~mL}$ de meio de respiração, substrato de sítio I e substrato de sítio II com rotenona. Utilizou-se $2 \mu \mathrm{M}$ da sonda Amplex ${ }^{\circledR}$ Red, que na presença de $1 \mathrm{U} / \mathrm{mL}$ de horseradish peroxidase (HRP), atua como doador de elétrons durante a redução de $\mathrm{H}_{2} \mathrm{O}_{2}$ em $\mathrm{H}_{2} \mathrm{O}$. O produto resultante é a resorufina (Figura 15), um composto que emite fluorescência detectada em comprimentos de onda de excitação e emissão de 563 nm e $587 \mathrm{~nm}$ respectivamente (ZHOU et 
al., 1997). A produção de EROs foi monitorada durante 10 minutos (Figura 16). Os cálculos foram feitos subtraindo-se a fluorescência inicial da fluorescência final e dividindo este valor pela variação do tempo.

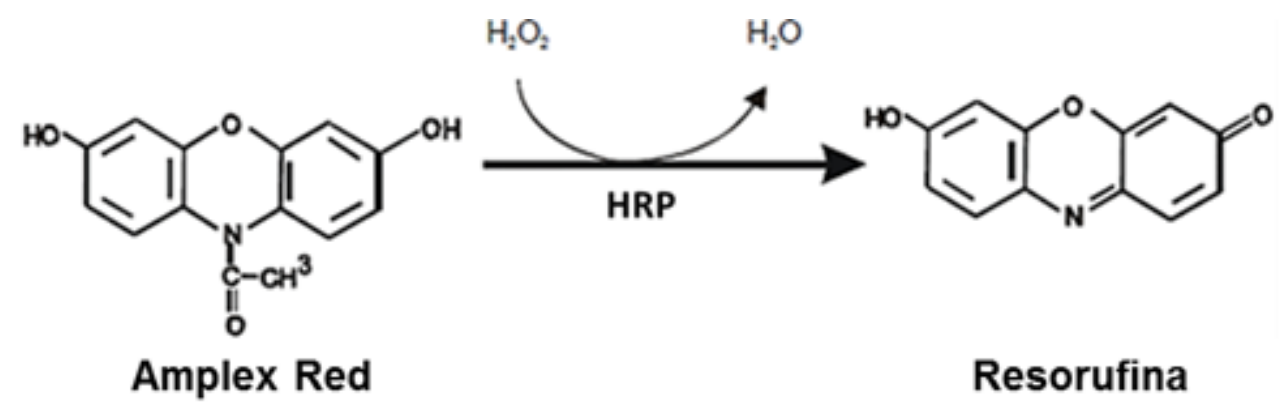

Figura 15: Conversão de Amplex Red em Resorufina. A HRP usa o Amplex Red como doador de elétrons durante a redução de peroxido de hidrogênio em água. O composto resultante é a resorufina, um composto que emite fluorescência em comprimentos de onda de excitação e emissão de $563 \mathrm{~nm}$ e $587 \mathrm{~nm}$, respectivamente.

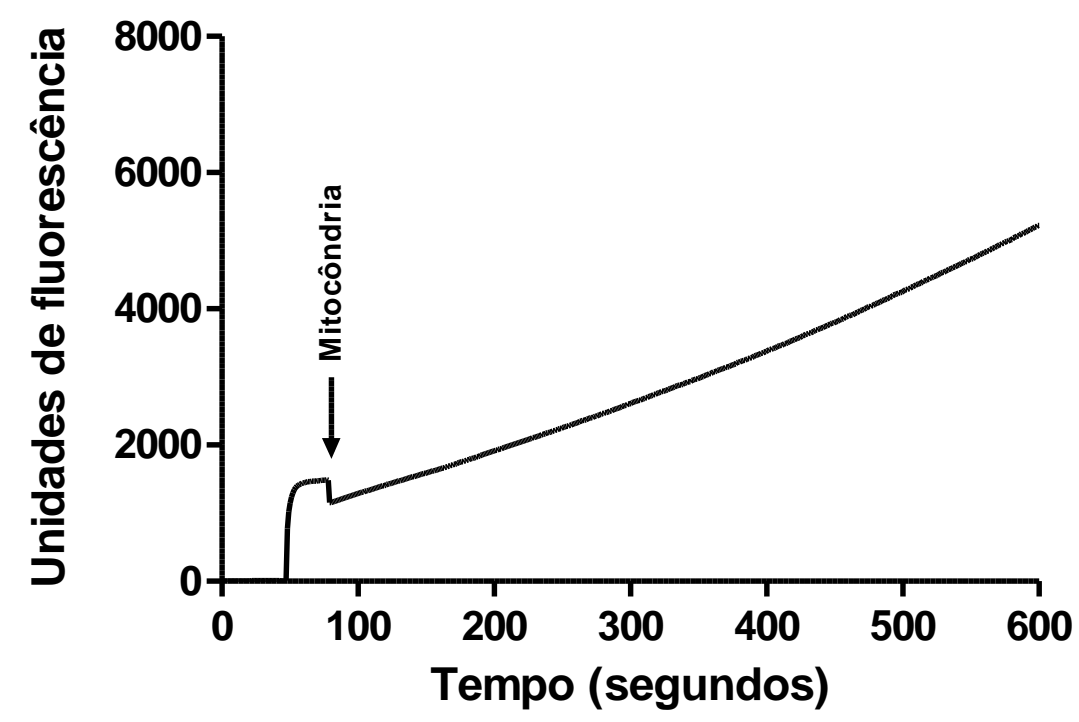

Figura 16: A Figura mostra o momento da injeção da mitocôndria e o monitoramento de EROs durante 10 minutos (600 segundos).

\section{Ensaios utilizando tecidos permeabilizados}

\subsection{Meios utilizados}

Para realizar os ensaios com tecidos permeabilizados foram utilizados dois meios. $\mathrm{O}$ primeiro é o meio de permeabilização, também chamado de meio Biops, contendo $2 \mu \mathrm{g} / \mathrm{mL}$ de taurina, $20 \mu \mathrm{g} / \mathrm{mL}$ de imidazol, 0,5 $\mu \mathrm{g} / \mathrm{mL}$ de ditiotreitol (DTT), 2,77 $\mu \mathrm{g} / \mathrm{mL}$ de EGTA - $\mathrm{Ca}^{2+}$, $6,56 \mu \mathrm{g} / \mathrm{mL}$ de $\mathrm{MgCl}_{2}, 50 \mu \mathrm{g} / \mathrm{mL}$ de K-MES, 7,23 $\mu \mathrm{g} / \mathrm{mL}$ de EGTA-KOH e pH 7,1. No momento do uso, a $4^{\circ} \mathrm{C}$, foi adicionado $5,77 \mu \mathrm{g} / \mathrm{mL}$ de ATP e $15 \mu \mathrm{g} / \mathrm{mL}$ de fosfocreatina. 
O meio utilizado para a respiração dos tecidos foi o Mitomed R05 (MIR 05), contendo $0,5 \mu \mathrm{g} / \mathrm{mL}$ de EGTA, $3 \mu \mathrm{g} / \mathrm{mL}$ de $\mathrm{MgCl}_{2}, 60 \mu \mathrm{g} / \mathrm{mL}$ de K-lactobionato, $20 \mu \mathrm{g} / \mathrm{mL}$ de taurina, $10 \mu \mathrm{g} / \mathrm{mL}$ de KH2PO4, $20 \mu \mathrm{g} / \mathrm{mL}$ de HEPES, $110 \mu \mathrm{g} / \mathrm{mL}$ de sacarose e $1 \mathrm{~g} / \mathrm{L}$ de BSA livre de ácido graxo em $\mathrm{pH} 7,1$.

\subsection{Permeabilização dos tecidos}

\subsubsection{Fígado}

Uma pequena fatia do fígado foi rapidamente retirada, inserida em $1 \mathrm{~mL}$ de meio Biops gelado e cortada em pedaços de aproximadamente $1 \mathrm{~m}^{3}$. Em seguida permaneceu em meio Biops gelado complementado com $1 \mu \mathrm{L}$ de uma solução de saponina $5 \mathrm{mg} / \mathrm{mL}$, o qual permaneceu por 5 minutos sob leve agitação em banho de gelo.

\subsubsection{Sóleo}

O músculo foi totalmente retirado e inserido em $1 \mathrm{~mL}$ de meio Biops gelado e com auxílio de uma lupa e pinça de ponta fina, o músculo foi cortado em fatias e as fibras dessas fatias foram cuidadosamente separadas a fim de não danifica-las. Em seguida foram inseridas em meios Biops gelado acrescido de $1 \mu \mathrm{L}$ de uma solução de saponina $5 \mathrm{mg} / \mathrm{mL}$, mantido em banho de gelo sob leve agitação por 20 minutos.

\subsubsection{Cérebro}

O protocolo de permeabilização de cérebro utilizado foi modificado de BENANI et al., 2009. O cérebro foi totalmente retirado, inserido em $2 \mathrm{~mL}$ de meio Biops gelado $4^{\circ} \mathrm{C}$ e atraves de uma lupa e aparatos cirúrgicos, foi possível dissecar tal tecido para obter o hipocampo. Aproximadamente metade do tecido dissecado foi congelado e o restante utilizado na experimentação em pequenos pedaços de aproximadamente $1 \times 1 \times 2 \mathrm{~mm}$. Tais porções foram inseridos em $2 \mathrm{~mL}$ de meio Biops gelado complementado com $20 \mu \mathrm{L}$ de solução de saponina 5 $\mathrm{mg} / \mathrm{mL}$ e mantidos por 20 minutos a $4^{\circ} \mathrm{C}$ sob leve agitação (BENANI et al., 2009). Posteriormente as biópsias foram transferidas para uma solução gelada de $0,1 \%$ de BSA e mantidas sob leve agitação por 5 minutos no gelo.

\subsection{Determinação do consumo de oxigênio dos tecidos}

Neste experimento, verificou-se o consumo de oxigênio no eletrodo do tipo oxygraph2k (Oroboros Instruments - High Resolution Respirometry) com agitação magnética (300 rpm) e a $37^{\circ} \mathrm{C}$ para os tecidos do músculo e do fígado e $750 \mathrm{rpm}$ a $30^{\circ} \mathrm{C}$ para o tecido do cérebro. $\mathrm{Na}$ 
câmara do oxígrafo, contendo $2 \mathrm{~mL}$ de meio MIR 05, foram inseridas amostras dos tecidos permeabilizados e após o fechamento da câmara, iniciamos a mensuração da respiração com a incorporação de diferentes compostos, dentre os quais, no fígado utilizamos $10 \mu \mathrm{g} / \mathrm{mL}$ de succinato; no músculo $10 \mu \mathrm{g} / \mathrm{mL}$ de piruvato, $2 \mu \mathrm{g} / \mathrm{mL}$ de malato e $9 \mu \mathrm{g} / \mathrm{mL}$ de glutamato; no cérebro $4 \mu \mathrm{g} / \mathrm{mL}$ de malato e $20 \mu \mathrm{g} / \mathrm{mL}$ de glutamato como substratos que propiciam a ativação dos complexos I e II da CTE. Por outro lado, a adição de $200 \mu \mathrm{M}$ de ADP, $1 \mu \mathrm{g} / \mathrm{mL}$ de oligomicina, $1 \mu \mathrm{M}$ de CCCP; $1 \mu \mathrm{g} / \mathrm{mL}$ de antimicina A foi igualmente incorporada nos diferentes tecidos estudados (Figura 17).

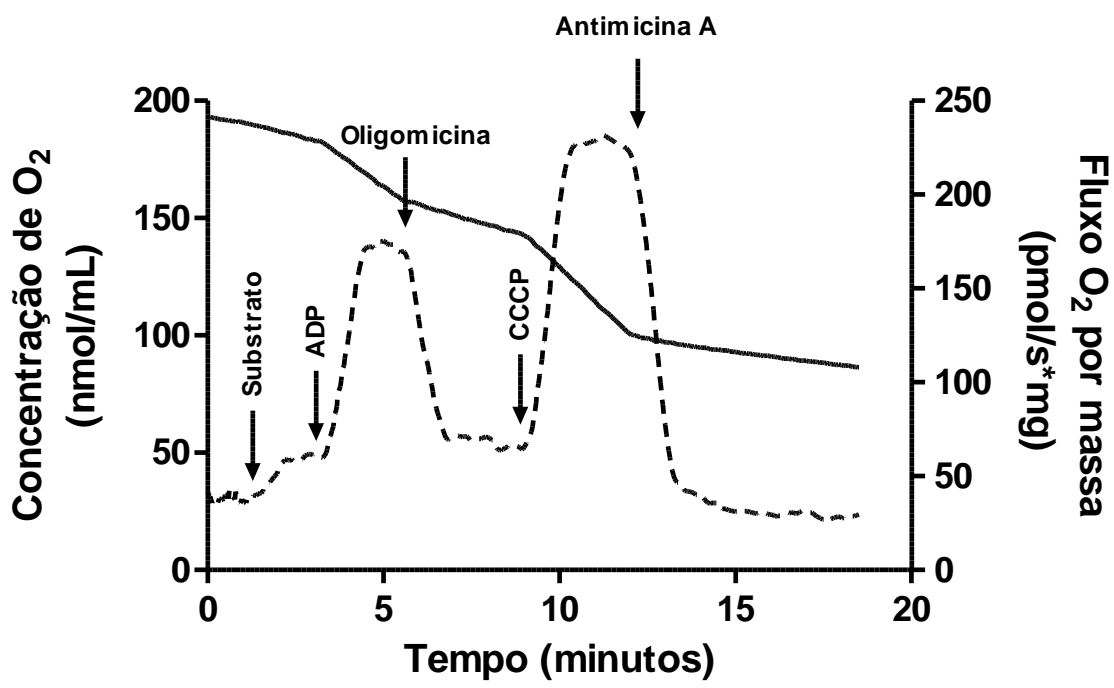

-. Fluxo $\mathrm{O}_{2}$ por massa (pmol/s*mg)

- Concentração de $\mathrm{O}_{2}(\mathrm{nmol} / \mathrm{mL})$

Figura 17: Sequência das adições dos compostos durante o ensaio para a determinação do consumo de oxigênio nos tecidos permeabilizados.

\subsection{Produção de espécies reativas de oxigênio (EROs) em tecidos permeabilizados}

Nos tecidos permeabilizados a produção de EROs foi monitorada utilizando as biópsias e sob agitação. $\mathrm{O}$ experimento procedeu adicionando diretamente na cubeta $2 \mathrm{~mL}$ de MIR 05, as biópsias (fígado, sóleo e hipocampo), os substratos específicos para cada tecido utilizados na respiração, $2 \mu \mathrm{M}$ da sonda Amplex ${ }^{\circledR}$ Red, e $1 \mathrm{U} / \mathrm{mL}$ de horseradish peroxidase (HRP). Os tecidos foram igualmente mantidos a $37^{\circ} \mathrm{C}$ sob agitação e monitorada espectrofluorimetricamente (Hitachi F-4500) durante 10 minutos, usando comprimentos de onda de excitação e emissão de $563 \mathrm{~nm}$ e $587 \mathrm{~nm}$ respectivamente (ZHOU et al., 1997). Os 
cálculos foram feitos subtraindo-se a fluorescência inicial da fluorescência final, posteriormente dividindo este valor pela variação do tempo neste intervalo e normalizados por proteínas totais.

\subsection{Dosagem de proteínas}

Para normalização dos dados obtidos com tecidos foram realizadas dosagens de proteínas totais. Para tal condição utilizamos o método de Bradford, proposto por Marion Bradford em 1976. A técnica se baseia na ligação das proteínas ao reagente Coomassie Brilliant Blue G-250, onde há mudança na absorção de $365 \mathrm{~nm}$ para $595 \mathrm{~nm}$, sem qualquer interferência de íons sódio ou potássio (BRADFORD, 1976).

Após os ensaios de respiração e EROs, todo o conteúdo da cubeta do fluorímetro e câmara do oxígrafo foram acrescidos de $500 \mu \mathrm{L}$ em uma solução de KOH 8M. Posteriormente permaneceram em banho maria a $37^{\circ} \mathrm{C}$ por 10 minutos seguida por agitação leve em vortéx. $\mathrm{O}$ reagente de Bradford (Bio-Rad ${ }^{\circledR}$ ) foi diluído quatro vezes, assim como as amostras. A curva de calibração foi feita com BSA e a absorbância foi medida em um leitor de microplaca a $595 \mathrm{~nm}$. Para normalizar, os valores dos dados obtidos nos experimentos foram divididos pela dosagem de proteínas.

\section{Determinação do estado redox do fígado}

\subsection{Proteína carbonilada}

A princípio foram pesados, aproximadamente, $50 \mathrm{mg}$ de tecido hepático que foi homogeneizado em $400 \mu \mathrm{L}$ de tampão Tris $0,1 \mathrm{M}$ gelado no sistema Potter-Elvehjem acoplado a um pistão para microtubos. Em seguida foi adicionado $600 \mu \mathrm{L}$ de tampão Tris $0,1 \mathrm{M}$ gelado e o homogenato foi centrifugado (rotor F 45-30-11, Eppendorf 5810R) a 1500g por 10 minutos a $4^{\circ} \mathrm{C}$ em triplicata. Após a centrifugação, cerca de $300 \mu \mathrm{L}$ do sobrenadante foram coletados e completou-se o volume até $1 \mathrm{~mL}$ com água mili-Q em tubos cônicos tipo Falcon de $15 \mathrm{~mL}$. Posteriormente foram incorporados $2 \mathrm{~mL}$ de TCA $10 \%$ e a solução foi centrifugada (rotor A4-81, Eppendorf $5810 \mathrm{R}$ ) a $500 \mathrm{~g}$ por 2 minutos a $4^{\circ} \mathrm{C}$. O sobrenadante foi desprezado e adicionamos e em uma das amostras da triplicata $1 \mathrm{~mL}$ de $\mathrm{HCl}$ 2,5 $\mathrm{M}$ e nas outras duas $1 \mathrm{~mL}$ de DNFH (preparado em $\mathrm{HCl} 2,5 \mathrm{M}$ ). As triplicatas foram incubadas por 1 hora a $37^{\circ} \mathrm{C}$ na ausência de luz. Após este tempo foram adicionados $4 \mathrm{~mL}$ de TCA $10 \%$ e esta solução permaneceu por 10 minutos em banho de gelo. Os tubos foram centrifugados novamente a $500 \mathrm{~g}$ por 2 minutos a $4^{\circ} \mathrm{C}$, sequencialmente ao descarte do sobrenadante. O pellet foi lavado duas 
vezes com $2 \mathrm{~mL}$ de etanol: acetato de etila 1:1. Logo após foi centrifugado na mesma condição anterior. O pellet foi ressuspendido em $2 \mathrm{~mL}$ de guanidina $6 \mathrm{M}$ e as amostras foram incubadas a temperatura ambiente com agitação por 40 minutos. Ao término do tempo de agitação, as amostras foram submetidas a leituras no espectrofotômetro, sendo a absorbância no comprimento de onda em 370 nm e guanidina utilizada como branco. Para a normalização do experimento, foi estimado a concentração de proteínas totais pelo método de Bradford (BRADFORD, 1976), com isso, os nossos resultados correspondem a absorbância das amostras dividida pela concentração de proteína e o resultado dividido pelo coeficiente de extinção molar $\left(1,8 \mathrm{M}^{-1} \cdot \mathrm{cm}^{-1}\right)$.

\subsection{Relação Glutationa reduzida (GSH) e glutationa oxidada (GSSG)}

Para incorporar mais um aspecto do estado redox em nossos resultados, cerca de 20 a $40 \mathrm{mg}$ de tecido hepático foram homogeneizados em $400 \mu \mathrm{L}$ de tampão Tris. Em seguida, foi adicionado $200 \mu \mathrm{L}$ de ácido tricloroacético (TCA) 30\% e $600 \mu \mathrm{L}$ de tampão Tris e centrifugado a $2000 \mathrm{~g}$ por 6 minutos a $4^{\circ} \mathrm{C}$, sendo o sobrenadante utilizado nos ensaios realizados em placa de 96 poços de poliestireno preto. Todas as adições foram seguidas por agitação em mixer e a fluorescência foi detectada em comprimentos de onda de excitação e emissão de $350 \mathrm{~nm}$ e 420 $\mathrm{nm}$, respectivamente.

\subsubsection{Glutationa reduzida (GSH)}

Para a determinação de GSH foram utilizados $10 \mu \mathrm{L}$ do sobrenadante, que foram acrescidos de $204 \mu \mathrm{L}$ de tampão fosfato e $100 \mu \mathrm{L}$ de OPT (preparado no momento do uso e ao abrigo de luz). A referida solução foi incubada por 15 minutos a temperatura ambiente e logo após foi realizada a leitura espectrofluorimetricamente.

\subsubsection{Glutationa oxidada (GSSG)}

Igualmente como na determinação de GSH, coletou-se $10 \mu \mathrm{L}$ de sobrenadante e em seguida foi adicionado $100 \mu \mathrm{L}$ de tampão fosfato e $4 \mu \mathrm{L}$ de NEM. Foi incubado por 30 minutos a temperatura ambiente. Procedeu-se com a adição de $100 \mu \mathrm{L}$ de $\mathrm{NaOH} 1 \mathrm{M}$ e $10 \mu \mathrm{L}$ de OPT e a incubação por mais 15 minutos a temperatura ambiente. E por fim, a detecção da fluorescência. 


\section{Quantificação de mRNA de UCP-2 no fígado, UCP-5 no cérebro e PGC1- $\alpha$ no sóleo}

\subsection{Extração de RNA}

Aproximadamente $50 \mathrm{mg}$ de tecido foram homogeneizados em $400 \mu \mathrm{L}$ de TRIzol ${ }^{\circledR}$ Reagent (Life Technologies ${ }^{\circledR}$ ). Em seguida, foi adicionado mais $600 \mu \mathrm{L}$ de TRIzol ${ }^{\circledR}$ Reagent. A extração do RNA procedeu de acordo com o protocolo do fabricante do TRIzol ${ }^{\circledR}$ Reagent (LIFE TECHNOLOGIES, 2012). Ao final da extração, o RNA foi ressuspendido em água RNase free (Nuclease-Free Water, Qiagen ${ }^{\circledR}$ ) e quantificado utilizando NanoDrop Spectrophotometer (Thermo Fisher Scientific ${ }^{\circledR}$ ).

\subsection{Síntese de cDNA}

A síntese de cDNA foi feita utilizando o kit comercial da Promega-Madison, WI, USA e 1,5 $\mu \mathrm{g}$ de RNA. Para tanto houve a preparação de um mix contendo $5 \mu \mathrm{L}$ Buffer reaction (5X); $4 \mu \mathrm{L}$ de $\mathrm{MgCl}_{2}(25 \mu \mathrm{g} / \mathrm{mL}) ; 0,3 \mu \mathrm{L}$ de Oligo dT primers $(500 \mu \mathrm{g} / \mathrm{mL}) ; 2 \mu \mathrm{L}$ de dNTP $(10$ $\mu \mathrm{g} / \mathrm{mL}) ; 0,2 \mu \mathrm{L}$ de RNase in ${ }^{\circledR}(40 \mathrm{u} / \mu \mathrm{L}) ; 0,45 \mu \mathrm{L}$ de RT intron $(160 \mathrm{u} / \mu \mathrm{L})$. Inicialmente foi incubado por 5 minutos a temperatura ambiente $\left(25^{\circ} \mathrm{C}\right)$, depois durante uma hora a $42^{\circ} \mathrm{C}$ e, finalmente por 15 minutos a $70^{\circ} \mathrm{C}$.

\subsection{Real Time qPCR}

A quantificação de mRNA de UCP-2 (fígado), UCP-5 (cérebro), PGC1- $\alpha$ (sóleo) foi realizada em triplicata e a partir do cDNA diluído 4 vezes $(1 \mu \mathrm{L}$ de cDNA : $3 \mu \mathrm{L}$ de água), utilizando-se Eppendorf Realplex4 Mastercycle Instrument (Eppendorf). Cada poço da placa de PCR continha $2 \mu \mathrm{L}$ de cDNA diluído e $8 \mu \mathrm{L}$ de um mix composto por $5 \mu \mathrm{L}$ de SsoFast EvaGreen ${ }^{\circledR}\left(\right.$ Bio-Rad $\left.^{\circledR}\right), 0,5 \mu \mathrm{L}$ de primer reverse $(10 \mu \mathrm{M}), 0,5 \mu \mathrm{L}$ de primer foward $(10 \mu \mathrm{M})$ e $2 \mu \mathrm{L}$ de água RNase free (Nuclease-Free Water, Qiagen ${ }^{\circledR}$ ). A quantificação relativa da expressão dos genes de interesse foi determinada por normalização com $\beta$-actina, utilizando o método $\Delta \Delta \mathrm{Ct}$ (WINER et al., 1999). Todos os primers utilizados para a RT-PCR foram adquiridos da Sigma-Aldrich ${ }^{\circledR}$ (Brasil) e sequência de nucleotídica de cada primer se encontra na Tabela 3. 
Tabela 3: Sequência de nucleotídeos dos primers utilizados para a quantificação de mRNA dos genes da UCP-2, UCP-5, PGC1- $\alpha$ e $\beta$-actina.

\begin{tabular}{cll}
\hline Gene & \multicolumn{1}{c}{ Sequência foward 5'-3' } & \multicolumn{1}{c}{ Sequência reverse 5'-3' } \\
\hline UCP-2 & ATGTGGTAAAGGTCCGCTTC & CATTTCGGGCAACATTGGG \\
UCP-5 & AACTGGCTTCGACTTGGAC & ATCAGGAACACAAAGAGGACC \\
& CAAGCCAAACCAACAACTTTAT & CACACTTAAGGTTCGCTCAATAG \\
PGC1- $\alpha$ & CTCT & TC \\
& ACCTTCTACAATGAGCTGCG & CTGGATGGCTACGTACATGG \\
\hline
\end{tabular}

\section{4 - Ensaio de cinética enzimática para determinação da atividade da citrato sintase}

Em banho de gelo, os tecidos foram homogeneizados em um tampão contendo 250 $\mu \mathrm{g} / \mathrm{mL}$ de sacarose, $1 \mu \mathrm{g} / \mathrm{mL}$ de EGTA e $10 \mu \mathrm{g} / \mathrm{mL}$ de HEPES-KOH (pH 7,2), proporcionalmente a massa, ou seja, a cada $50 \mathrm{mg}$ de tecido era utilizado $1 \mathrm{~mL}$ de tampão. $\mathrm{O}$ homogenato resultante foi centrifugado a $12000 \mathrm{G}$ por 10 minutos a $4^{\circ} \mathrm{C}$, sendo o sobrenadante coletado e utilizado na quantificação de proteínas totais pelo método de Bradford. Em uma placa de 96 poços, a cinética da citrato sintase foi determinada usando $50 \mu \mathrm{g}$ de proteína e detectada em comprimento de onda de $412 \mathrm{~nm}$ por 2 minutos com intervalos de 10 segundos em temperatura ambiente. O meio reacional foi composto por $0,1 \mu \mathrm{g} / \mathrm{mL}$ de acetil-coA, 0,1 $\mu \mathrm{g} / \mathrm{mL}$ de DTNB, 0,10\% de Triton X-100, 0,2- $\mu \mathrm{g} / \mathrm{mL}$ de oxaloacetato, 0,1 M de tampão Tris, pH 8,0. (KUZNETSOV; LASSNIG; GNAIGER, 2010).

\section{5- Análise estatística}

Os ensaios foram realizados em duplicata e triplicata. As análises estatísticas foram conduzidas utilizando-se Análise de Variância One Way ANOVA seguido do pós-teste de Newman-Keuls. A análise dos resultados de respiração com mitocôndrias isoladas na ausência e presença de LA foram analisadas utilizando o teste t não pareado seguido do pós-teste de Newman-Keuls. Os dois testes foram aplicados pelo software estatístico GraphPad Prism ${ }^{\circledR}$ versão 5, USA.. Somente valores de $\mathrm{P}<0,05$ foram considerados significativos. 
Resultados 


\section{RESULTADOS}

\section{In vivo}

\subsection{Ganho de peso}

A princípio nós monitoramos semanalmente o peso dos camundongos (Figura 18A) para verificar se a suplementação com CLA e óleo de peixe isolados ou associados causaria alguma mudança no peso corporal dos animais. Observamos que não houve diferença significativa do ganho de peso entre os animais dos quatro grupos durante o período de tratamento (Figura 18B). Estes resultados corroboram com os trabalhos previamente realizados em nosso laboratório. Tanto o tratamento de camundongos somente com CLA (PEREIRA et al., 2012) ou em conjunto com óleo de oliva (BARALDI et al., 2016) não foi observado ganhou ou perda de peso, bem como SNEDDON et al., (2009) que observou o mesmo resultado em animais suplementados com óleo de peixe e CLA simultaneamente.

(A)

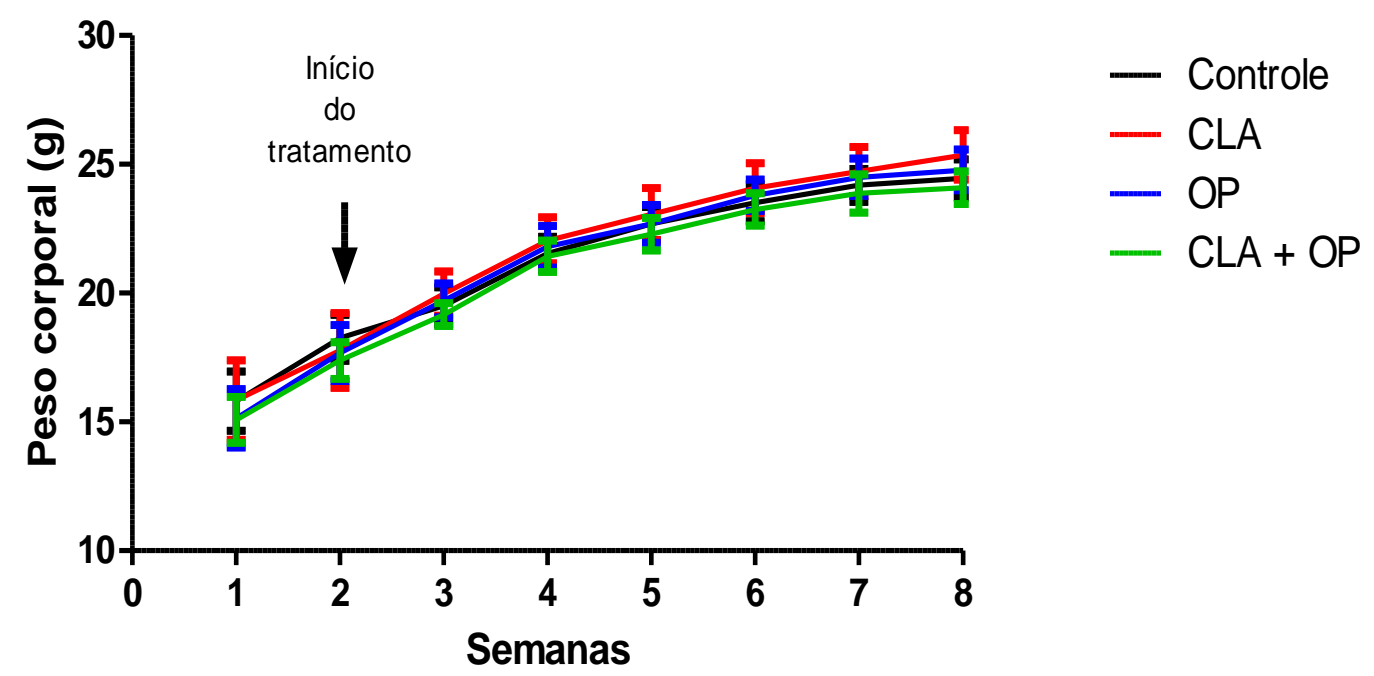


(B)

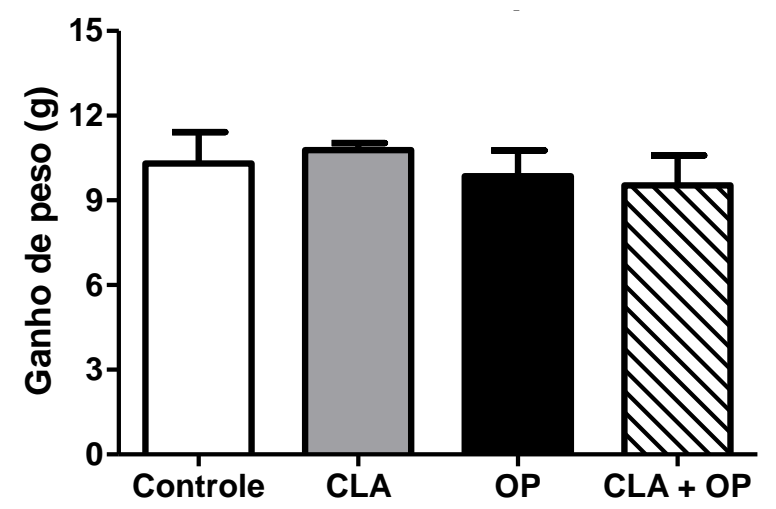

Figura 18: (A) Curva de monitoramento semanal do peso corporal de camundongos suplementados com CLA e OP sozinhos ou em conjunto e controles em função do período de tratamento. (B) Gráfico mostrando a média do ganho de peso final de cada grupo. Média \pm EPM. $n=5-6 . P<0,05$.

\subsection{Metabolismo corporal}

O calorímetro calcula o gasto de energia (EE) a partir do volume de oxigênio consumido $\left(\mathrm{VO}_{2}\right)$ e do volume de gás carbônico produzido $\left(\mathrm{VCO}_{2}\right)$. A relação entre o $\mathrm{VCO}_{2}$ e $\mathrm{VO}_{2}$ é referida como quociente respiratório (RQ) e demonstra o substrato energético predominantemente oxidado: quanto maiores, maior é a oxidação de glicose. Na figura 19 são mostrados os monitoramentos dos parâmetros do calorímetro $\left(\mathrm{VO}_{2}, \mathrm{VCO}_{2}\right.$, EE e RQ) durante 24 horas (19A, 19C, 19E e 19G) e também os gráficos apresentando médias e desvio padrão (19B, 19D, 19F e 19H) por cada grupo dos camundongos tratados. Após 30 dias de suplementação, verificamos que os animais tratados com CLA, óleo de peixe (OP) e ambos os óleos (CLA+OP) obtiveram valores de $\mathrm{VO}_{2}$ (Figura 19B), $\mathrm{VCO}_{2}$ (Figura 19D) e EE (Figura 19F) maiores que os animais tratados somente com ácido linoleico (controle). Além disso, os animais dos grupos que receberam óleo de peixe (OP e CLA+OP) durante o tratamento tiveram seu metabolismo corporal maior que os animais suplementados somente com CLA, mas não houve diferença entre os grupos OP e CLA + OP quando comparados entre si. Ao observarmos o gráfico referente aos valores de RQ (Figura 19H) notamos que não há diferença entre os grupos OP e CLA + OP em relação ao grupo controle, mas que os valores de RQ destes animais é significativamente diferente quando comparados aos animais tratados somente com CLA. 
(A)

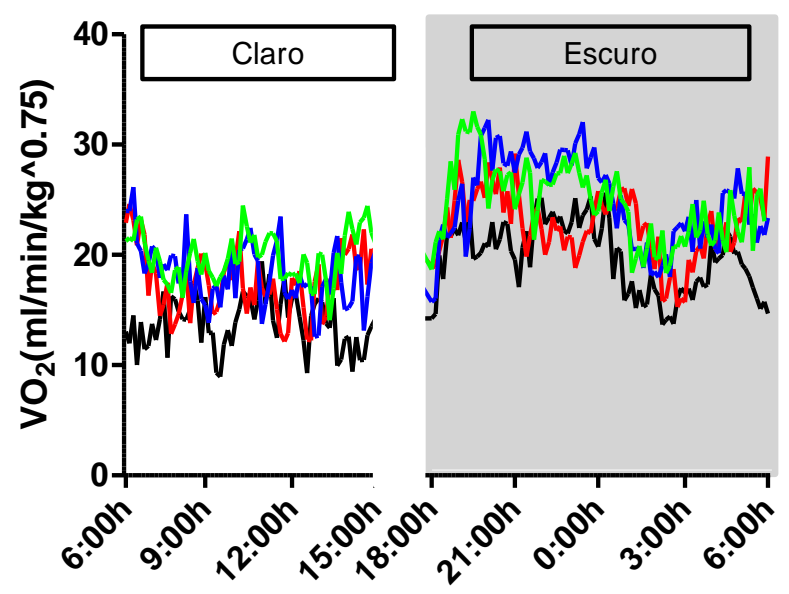

(C)

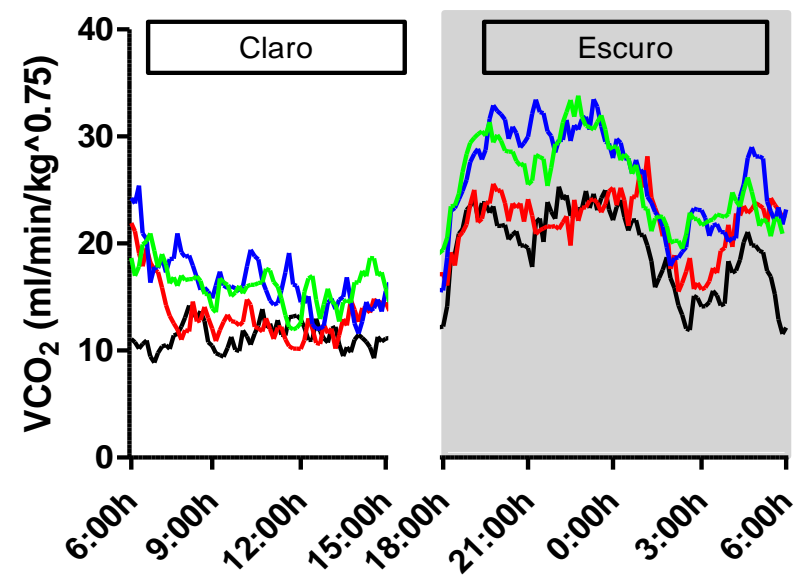

(E)

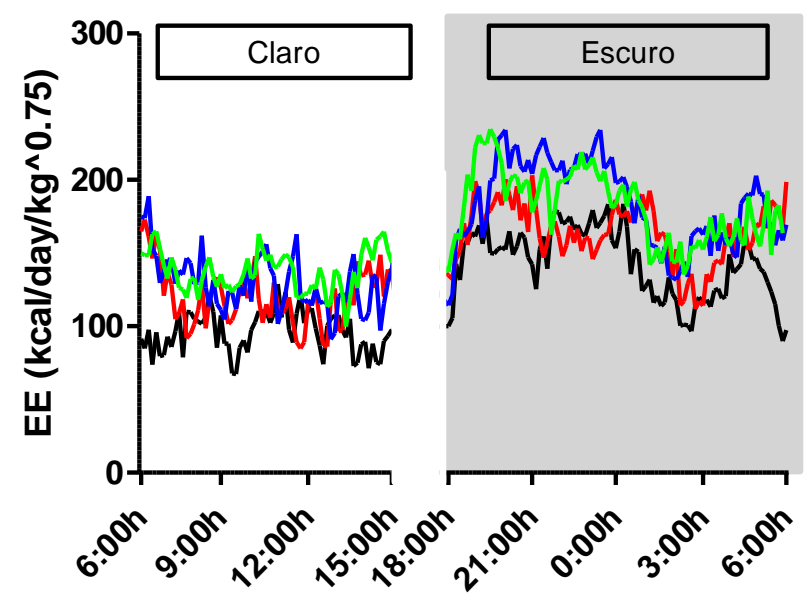

(B)

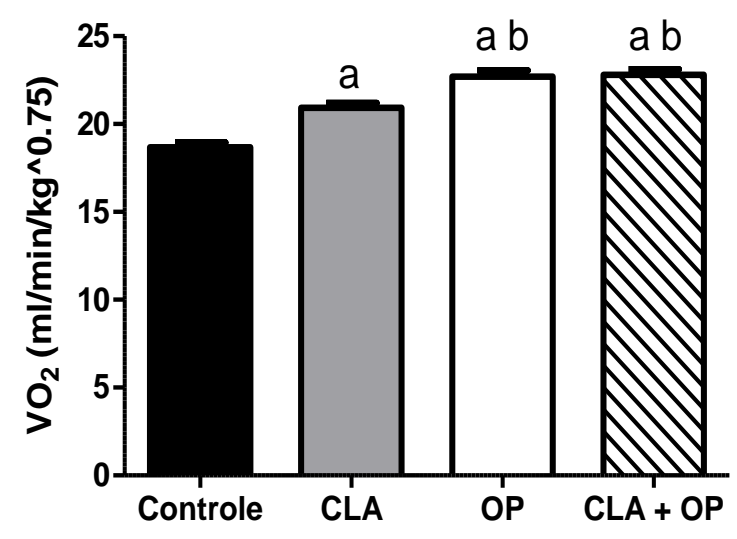

(D)

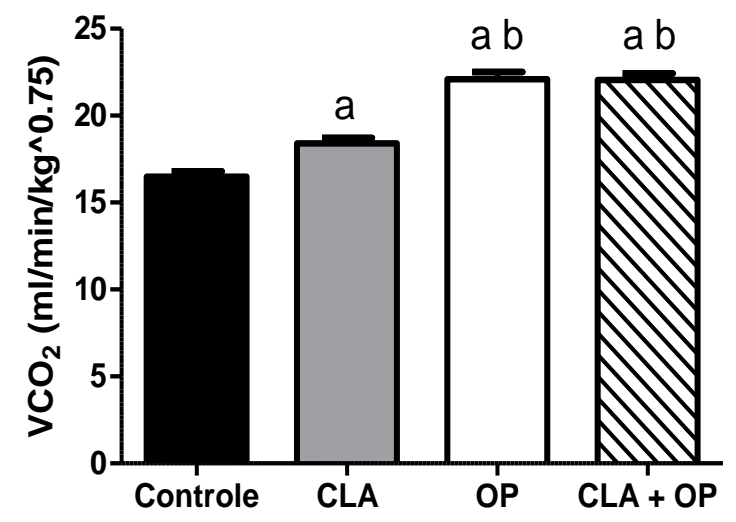

(F)

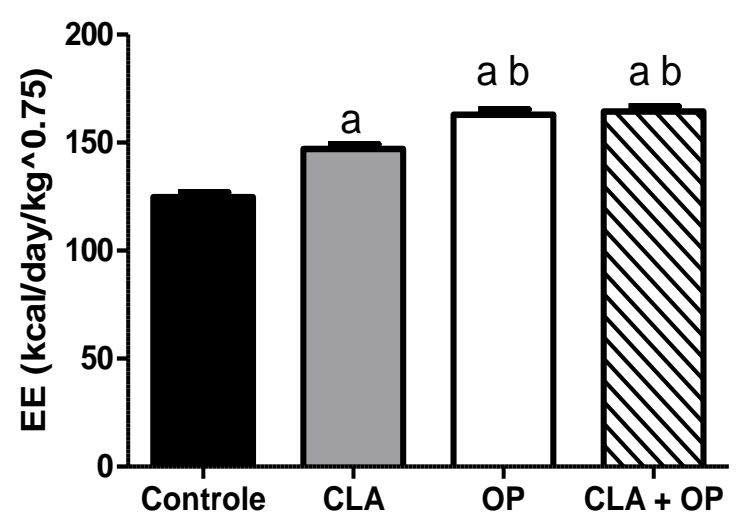


(G)

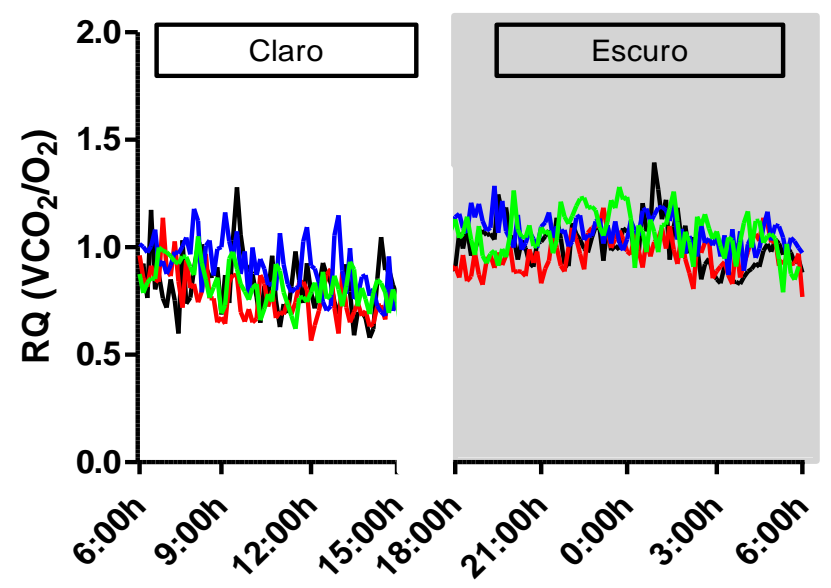

(H)

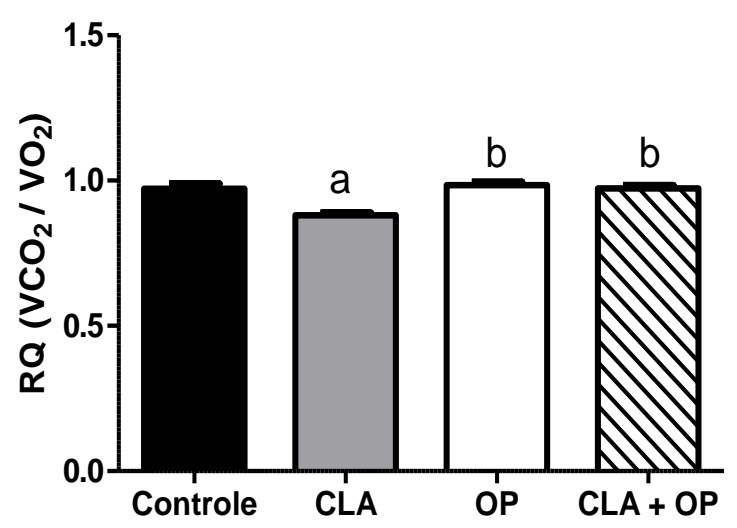

\section{Legenda:}

- Controle - OP

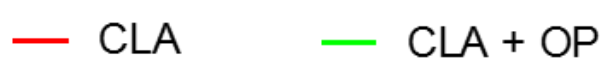

Figura 19: Monitoramento durante 24 horas do (A e B) volume de oxigênio consumido (VO2), (C e D) volume de gás carbônico produzido (VCO2), (E e F) gasto energético (EE, $\left.\mathrm{kcal} / \mathrm{dia} / \mathrm{kg}^{\wedge} 0,75\right)$ e $(\mathrm{G} \mathrm{e} \mathrm{H}) \mathrm{RQ}(\mathrm{VCO} 2 / \mathrm{VO} 2)$. Valores em $\mathrm{mL} / \mathrm{min} / \mathrm{Kg}^{\wedge} 0,75$. Média $\pm \mathrm{EPM}$. ${ }^{\mathrm{a}} \mathrm{P}<0,05$ vs controle, ${ }^{\mathrm{b}} \mathrm{P}<0,05$ vs CLA.

Camundongos (Mus musculus) são mamíferos roedores de hábitos noturnos, logo, eles dormem durante o dia e são ativos durante a noite, por isso decidimos monitorar a movimentação espontânea dos camundongos. Acompanhamos a movimentação vertical e horizontal dos camundongos por 24 horas e os resultados obtidos foram separados em fase claro e fase escuro (Figura 20). Visto que os animais dos grupos que receberam óleo de peixe (OP e $\mathrm{CLA}+\mathrm{OP}$ ) possuíam o metabolismo acentuado, surpreendentemente, eles se movimentavam horizontalmente muito menos que os animais do grupo controle e CLA (20A e 20B). Em relação a movimentação vertical (também chamada de levantamento) os animais do grupo OP se mostraram menos ativos quando comparados ao grupo CLA. Apesar dos animais do grupo CLA+OP apresentarem uma redução na atividade vertical em relação ao CLA (20C e 20D), este fato não foi estatisticamente significativo $(\mathrm{P}<0,05)$. Observa-se também que ao manipular camundongos no momento do tratamento, os animais que eram tratados com CLA eram mais 
agitados quando comparados aos animais que eram suplementados com óleo de peixe (OP e $\mathrm{CLA}+\mathrm{OP})$.

(A)

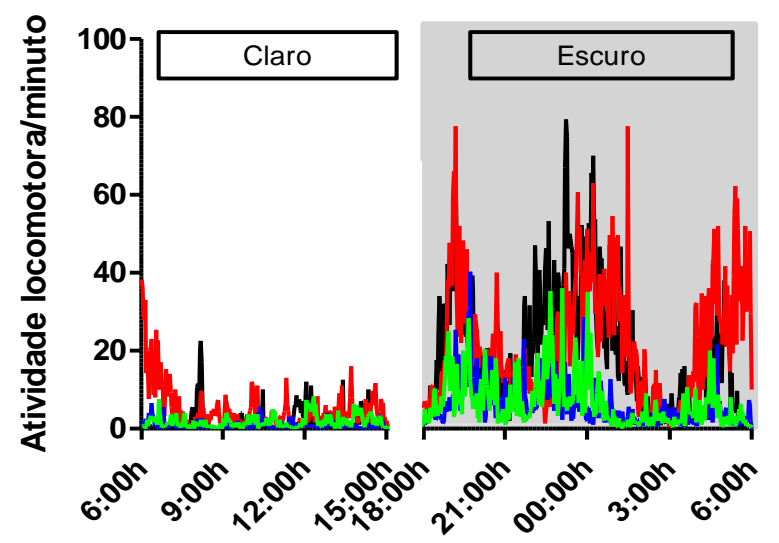

(C)

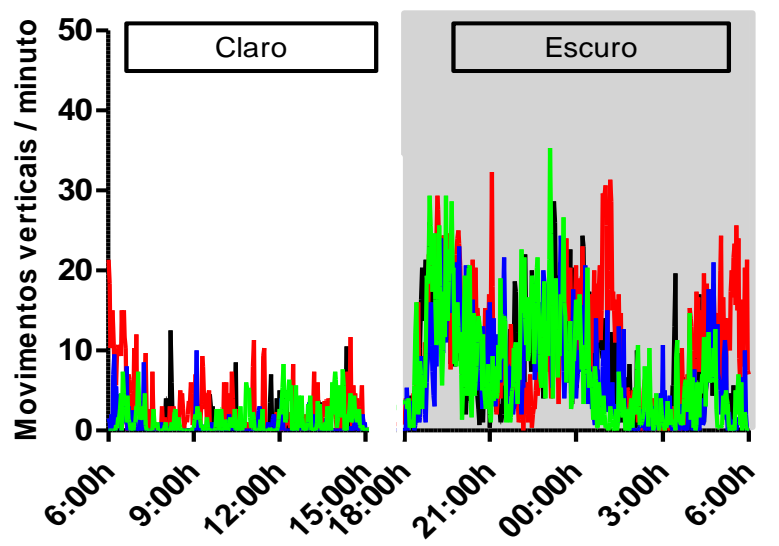

(B)

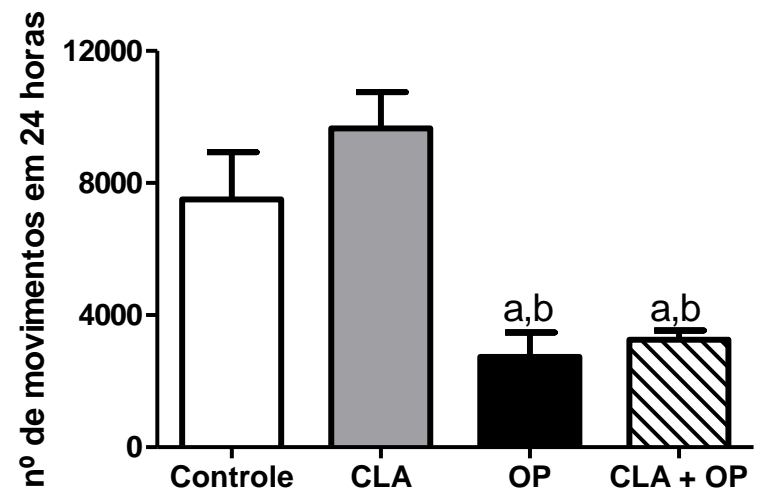

(D)

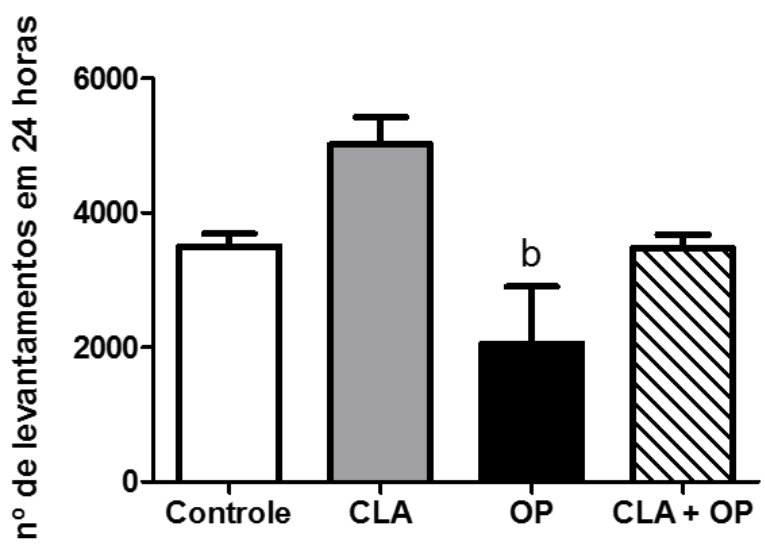

\section{Legenda:}

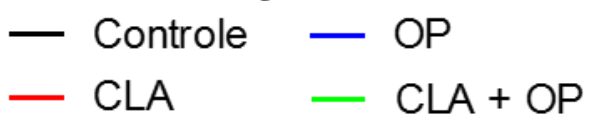

Figura 20: Monitoramento da atividade motora horizontal e vertical dos camundongos durante 24 horas, separado em fase claro e fase escuro. (A e B) atividade locomotora horizontal; (C e D) atividade motora vertical (levantamento). Média \pm EPM. a $\mathrm{P}<0,05$ vs controle, ${ }^{b} \mathrm{P}<0,05$ vs CLA. $n=4-5$.

\subsection{Parâmetros bioquímicos}

Com o intuito de verificar se a suplementação com CLA e OP isoladamente ou em conjunto causava alguma alteração no metabolismo da glicose dos animais, monitoramos os valores de glicemia a cada 15 minutos durante 2 horas após uma dosagem via gavagem de 1,5 
$\mathrm{g} / \mathrm{Kg}$ de solução de glicose. Os valores foram utilizados para construir a curva glicêmica (Figura 21A) e calcular a área sob a curva (Figura 21B). Os resultados do TTG são determinados pela secreção e ação da insulina na captação de glicose (AYALA et al., 2010). O resultado do TTG indica que os animais dos grupos que receberam CLA (CLA e CLA+OP) exibiram maiores valores de área sob a curva, ou seja, tiveram uma captação de glicose mais lenta quando comparados aos animais que receberam somente óleo de peixe (OP) e aos controles.

Para complementar os resultados do TTG, nós realizamos o teste de tolerância a insulina (TTI). O TTI é uma técnica utilizada para estimar a sensibilidade a insulina in vivo, sendo mensurada a velocidade de decaimento da glicose (KITT) após a injeção de uma quantidade conhecida de insulina (NETO; TAMBASCIA, 2006). A interpretação do TTI se baseia em quanto mais rápida e intensa for a queda da glicose, mais sensível o indivíduo é a insulina. $\mathrm{O}$ $\mathrm{K}_{\text {ITT }}$ corresponde a queda da glicose expressa em porcentagem/minuto e, quanto maior o $\mathrm{K}_{\text {ITT }}$ maior a sensibilidade a insulina (NETO; TAMBASCIA, 2006). Utilizando os valores de glicemia obtidos no TTI, construímos a curva de decaimento da concentração plasmática de glicose (Figura 21C). Nosso resultado mostra que os animais controle e os que receberam somente óleo de peixe tiveram valores de $\mathrm{K}_{\text {ITT }}$ maiores que os animais que receberam CLA sozinho ou em conjunto com o óleo de peixe (Figura 21D). Isso indica que os animais suplementados com CLA dispõe de resistência à insulina quando comparados aos animais que não receberam o óleo. Com base nos resultados tanto do TTG quanto do TTI podemos constatar que a suplementação com óleo de peixe não reverteu os efeitos do CLA sobre o metabolismo de glicose circulante. 
(A)

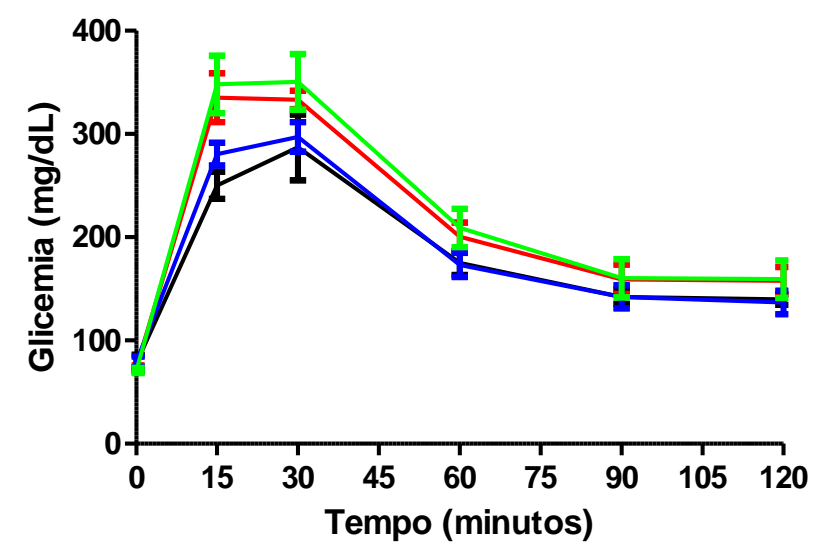

(C)

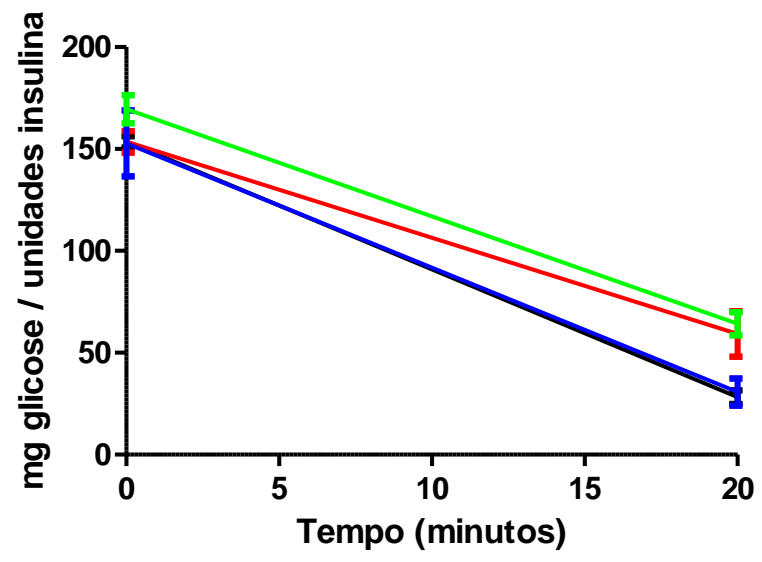

(B)

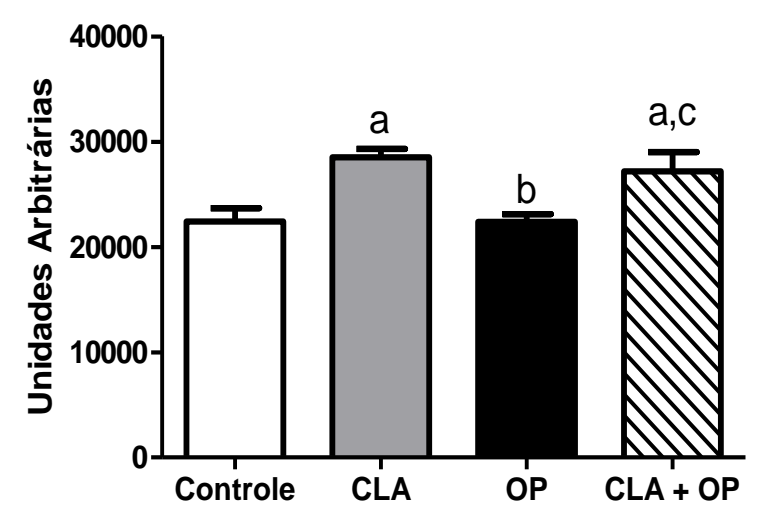

(D)

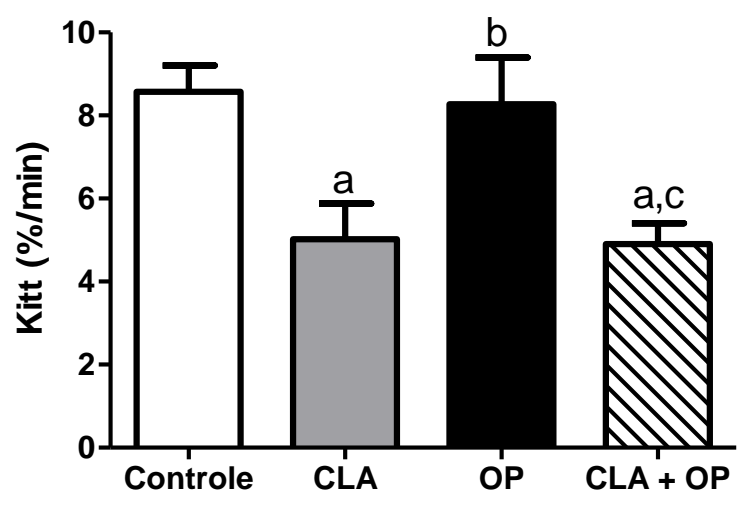

Legenda:

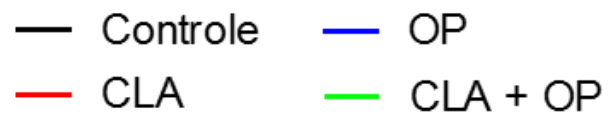

Figura 21: (A) curva glicêmica dos animais controle e suplementados com CLA e OP somente ou em conjunto, durante 120 minutos. (B) medida da área sob a curva do TTG (C) curva de decaimento da concentração de glicose plasmática nos animais controle e suplementados com CLA e OP somente ou em conjunto nos primeiros 20 minutos após a injeção de insulina. (D) gráfico da velocidade constante de desaparecimento da glicose plasmática $\left(\mathrm{K}_{\mathrm{itt}}\right)$. Média $\pm \mathrm{EPM}$. ${ }^{\mathrm{a}} \mathrm{P}<0,05$ vs controle, ${ }^{\mathrm{b}} \mathrm{P}<0,05$ vs CLA, ${ }^{\mathrm{c}} \mathrm{P}<0,05$ vs OP. $\mathrm{n}=4-5$.

Para verificar se a suplementação dos camundongos com os óleos causava alguma modificação nos níveis plasmáticos de lipídeos, nós fizemos dosagens bioquímicas de triglicérides, colesterol total e colesterol HDL. Considerando $\mathrm{P}<0,05$, o gráfico da Figura 22A nos mostra que, em relação ao grupo controle, somente os animais que foram suplementados apenas com óleo de peixe apresentaram uma diminuição significativamente estatística das concentrações de colesterol total. Ainda nestes animais observamos valores maiores, porém não 
significativos, de colesterol HDL (Figura 22B). Não observamos diferença estatística nas concentrações circulantes de triglicérides entre os quatro grupos, apesar que os animais que receberam OP apresentaram valores menores (Figura 22C).

(A)

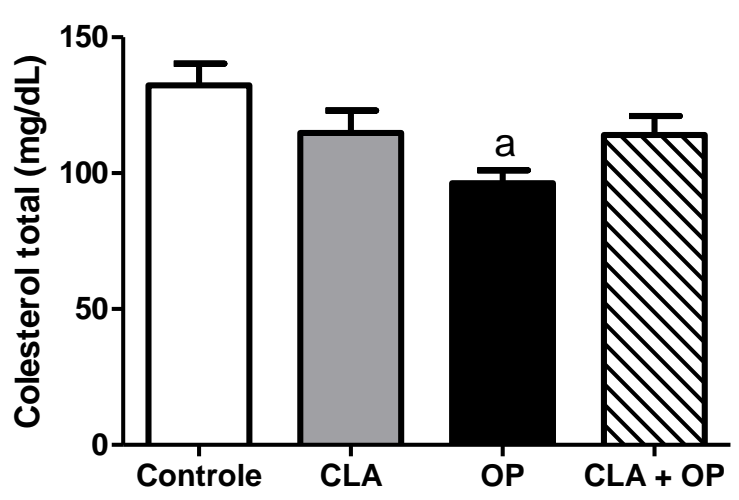

(B)

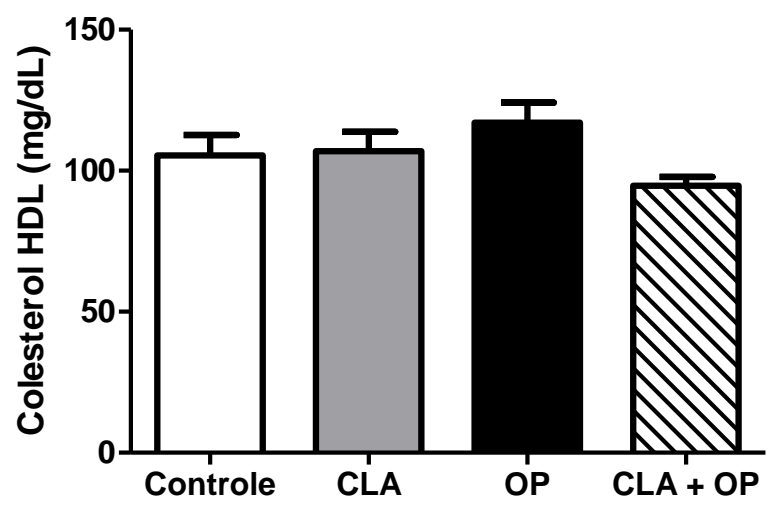

(C)

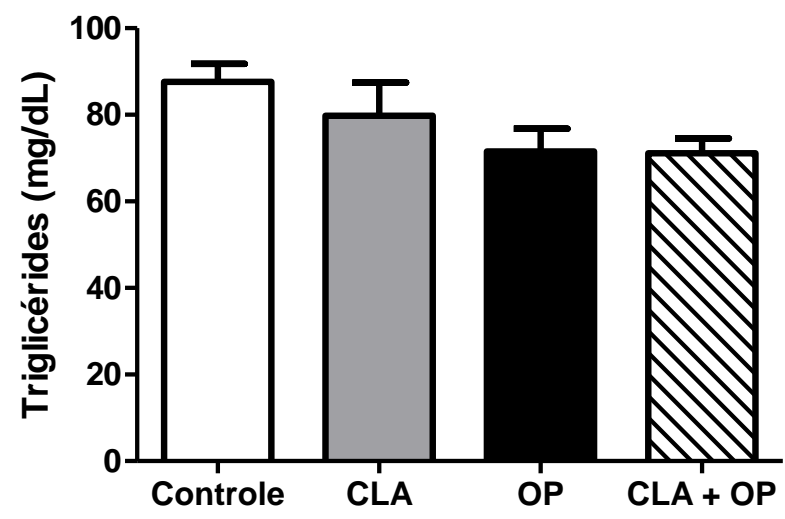

Figura 22: Concentração dos lipídeos plasmáticos circulantes em camundongos suplementados com CLA e OP somente e em conjunto e controle; (A) colesterol total e (B) colesterol HDL e (C) triglicérides Média \pm EPM. ${ }^{a} \mathrm{P}<0,05$ vs controle. $\mathrm{n}=5$.

\section{Ex vivo}

\subsection{Peso dos tecidos}

Após 60 dias de suplementação, os camundongos foram eutanasiados e os tecidos retirados foram pesados. O peso de cada tecido foi normalizado pelo peso do animal. Analisando as figuras $23 \mathrm{~A}$ e $23 \mathrm{~B}$ percebe-se uma leve queda no peso dos TAB e TAM dos animais que receberam apenas CLA ou em conjunto com óleo de peixe, quando comparados aos animais dos grupos controle e OP, mas do ponto de vista estatístico $(\mathrm{P}<0,05)$, esta diferença não foi significativa. Da mesma forma, não encontramos diferenças estatísticas nos pesos dos 
tecidos do cérebro (Figura 23C), músculos gastrocnêmio (Figura 23D) e sóleo (Figura 23E). No entanto, com relação ao tecido hepático, os animais do grupo CLA + OP possuem o fígado maior quando comparados aos animais dos grupos controle, CLA e OP (Figura 23F).

(A)

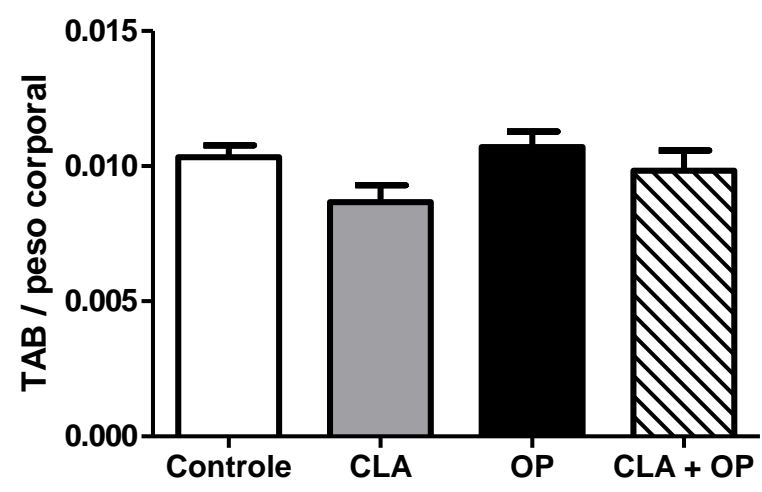

(C)

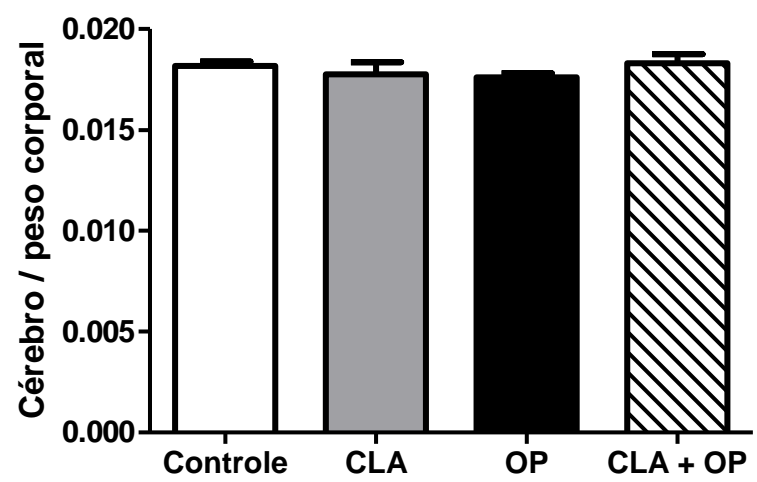

(E)

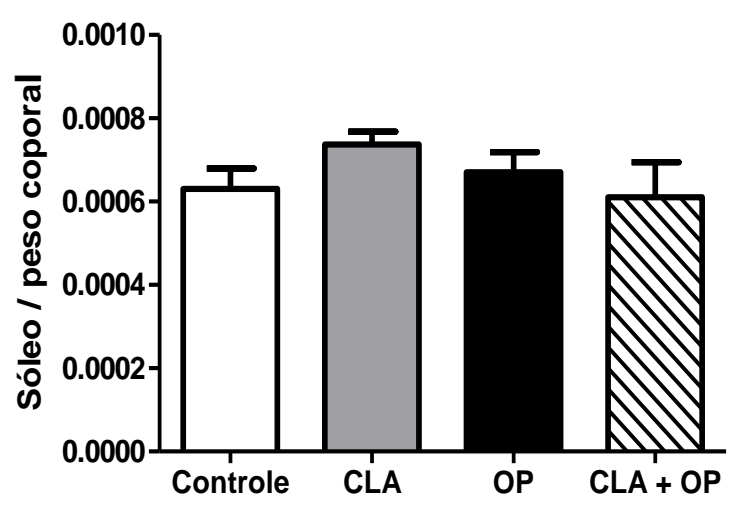

(B)

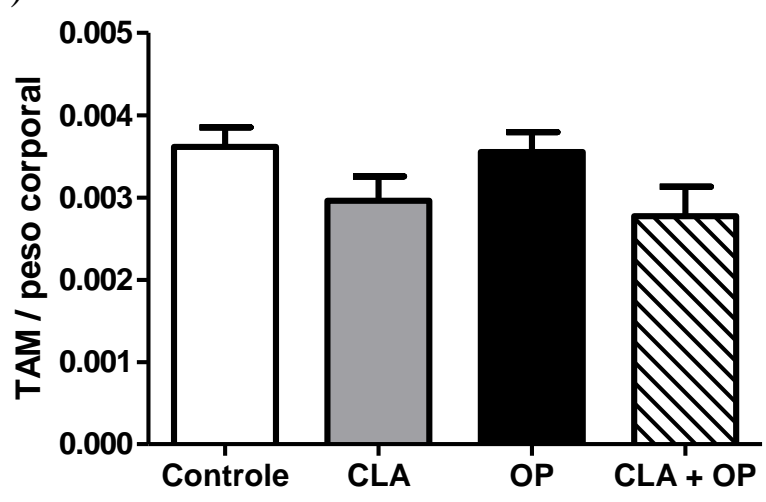

(D)

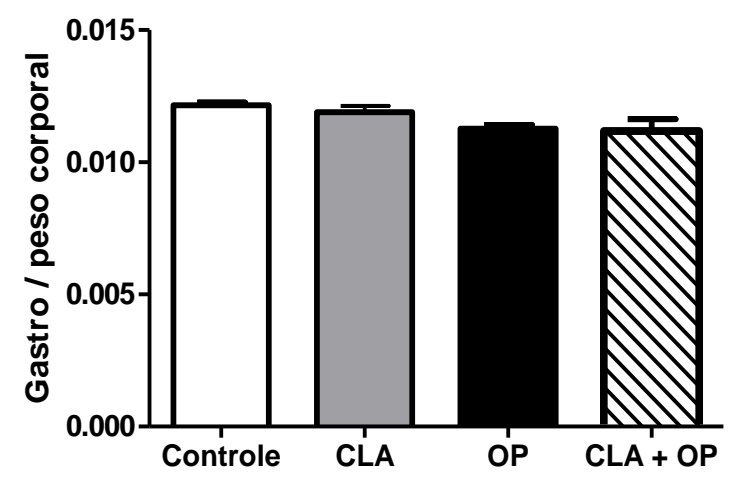

(F)

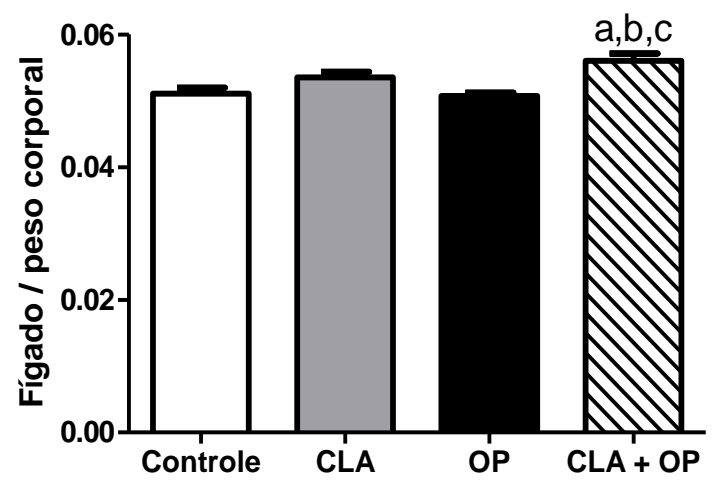

Figura 23: gráficos representando a razão entre o peso dos tecidos e o peso corporal de camundongos suplementados CLA, OP, CLA + OP e controle. (A) tecido adiposo branco (B) tecido adiposo marrom; (C) cérebro; (D) músculo gastrocnêmio; (E) músculo sóleo e (F) fígado. Média \pm EPM. ${ }^{a} \mathrm{P}<0,05$ vs controle, ${ }^{\mathrm{b}} \mathrm{P}<0,05$ vs $\mathrm{CLA},{ }^{\mathrm{c}} \mathrm{P}<0,05$ vs OP. $\mathrm{n}=5-15$. 


\subsection{Metabolismo mitocondrial}

\subsubsection{Fígado}

\subsubsection{Consumo de oxigênio do tecido hepático permeabilizado e de mitocôndrias}

isoladas.

Para verificar se o aumento do consumo de $\mathrm{O}_{2}$ está relacionado a um aumento no metabolismo mitocondrial no fígado, realizamos o monitoramento do consumo de $\mathrm{O}_{2}$ em mitocôndrias isoladas de fígado e no tecido hepático permeabilizado dos animais suplementados com CLA e óleo de peixe isolados ou em conjunto.

As mitocôndrias isoladas $(0,5 \mathrm{mg} / \mathrm{mL})$ foram incubadas em meio de respiração e energizadas com $5 \mu \mathrm{g} / \mathrm{mL}$ de glutamato/malato ou $5 \mu \mathrm{g} / \mathrm{mL}$ de succinato (substratos de complexo I ou II, respectivamente) e em seguida foram submetidas a respiração na ausência (barras brancas) e na presença (barras pretas) de $0,2 \mu \mathrm{M}$ de ácido linoleico (LA) (ver Figura 13). Após isto, foi adicionado ADP para determinação do estado de fosforilação (estado III) e, após a fosforilação foi determinado o estado de repouso (estado IV).

Analisando o estado de fosforilação (estado III) em mitocôndrias energizadas com glutamato/malato, encontramos velocidades semelhantes na presença e ausência de LA (Figura 24A), porém quando foram energizadas com succinato, houve redução significativa ( $p<0,05)$ nas velocidades de respiração nos quatro grupos (Figura 24B).

Se a mitocôndria não tiver um bom acoplamento de fosforilação oxidativa, espera-se um aumento na velocidade de consumo de $\mathrm{O}_{2}$ no estado IV e diminuição dos valores de $\mathrm{CR}$ (estado III / estado IV) e ADP/O. Sendo LA um substrato para UCPs, espera-se que as mitocôndrias que possuem maior expressão destas proteínas apresentem estas características. A razão ADP/O é utilizada para avaliar a eficiência de fosforilação das mitocôndrias, uma vez que ela representa o número de moléculas de ATP sintetizadas por cada átomo de oxigênio consumido. São utilizados valores de ADP/O de 2,5 e 1,5 para respirações realizadas com substratos respiratórios de complexo I e II respectivamente. O CR juntamente com ADP/O são utilizados também como parâmetros para demonstrar a funcionalidade da preparação mitocondrial (SALVADOR, 2003; HINKLE, 2005; NELSON; COX, 2014).

As velocidades do estado de repouso (estado IV) de mitocôndrias energizadas com glutamato/malato e succinato são apresentadas nas figuras $24 \mathrm{C}$ e $24 \mathrm{D}$ respectivamente. Observamos que LA aumenta relativamente o estado IV nos animais OP e OP associado ao CLA em ambos os substratos e, com succinato, soma-se o grupo tratado somente com CLA. 
Apesar disso, as razões do controle respiratório $(\mathrm{CR}=\mathrm{V} 3 / \mathrm{V} 4)$ das respirações com e sem LA se diferiram dentro do mesmo grupo com os dois substratos respiratórios (Figura 24E e 24F). Quando calculamos o $\triangle \mathrm{CR}$ (CR com LA - CR sem LA), ou seja, a variação do CR, observamos maiores variações nos animais tratados com CLA, porém esses valores não são estatisticamente diferentes entre os grupos (Figura 24H). Em relação a ADP/O, de forma geral todos os grupos apresentaram um decaimento na $\mathrm{ADP} / \mathrm{O}$ na presença de LA com ambos os substratos como mostram as figuras $24 \mathrm{I}$ e 24J. Porém, quando calculamos o $\triangle \mathrm{ADP} / \mathrm{O}(\mathrm{ADP} / \mathrm{O}$ sem $\mathrm{LA}-\mathrm{ADP} / \mathrm{O}$ com LA) para mitocôndrias energizadas com glutamato/malato não obtemos diferenças estatísticas $(\mathrm{P}<0,05)$ entre os grupos, mas percebe-se claramente que os animais suplementados com CLA sozinho ou em conjunto com óleo de peixe apresentam maiores valores de $\triangle \mathrm{ADP} / \mathrm{O}$ (maior variação da $\mathrm{ADP} / \mathrm{O}$ ) quando comparados aos animais que receberam somente óleo de peixe e controle (Figura 24K). Com succinato, o grupo CLA obteve valores maiores de $\triangle \mathrm{ADP} / \mathrm{O}$ em relação ao grupo controle, porém não foi diferente dos grupos OP e CLA+OP (Figura 24L).

(A)

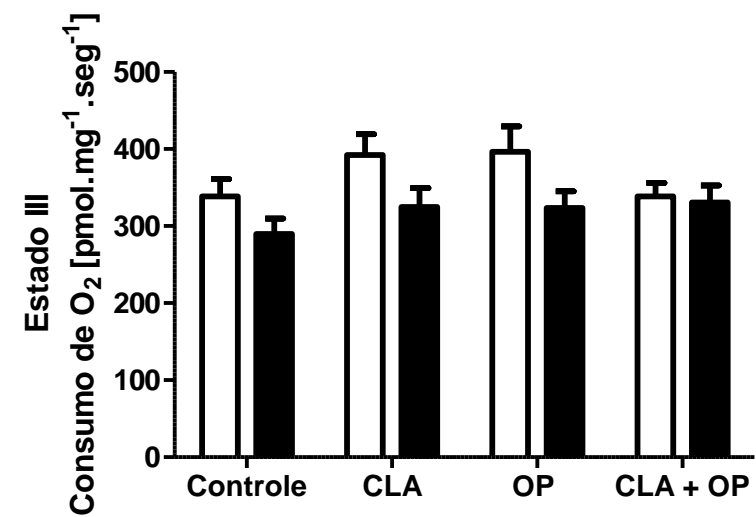

(C)

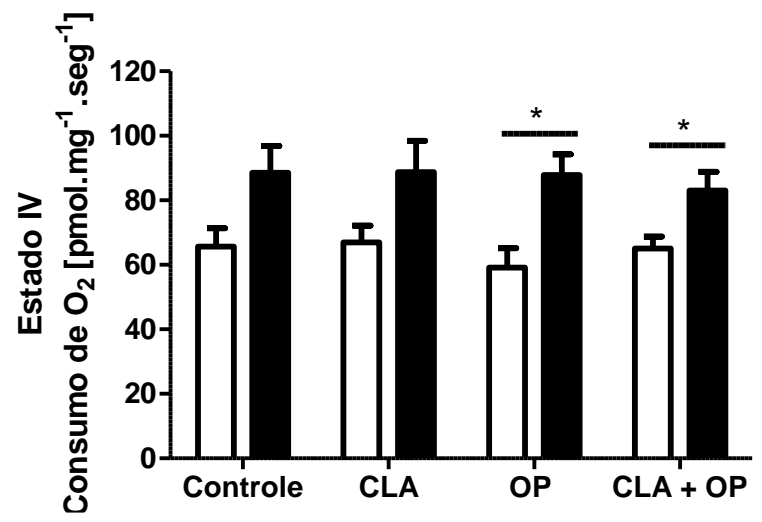

(B)

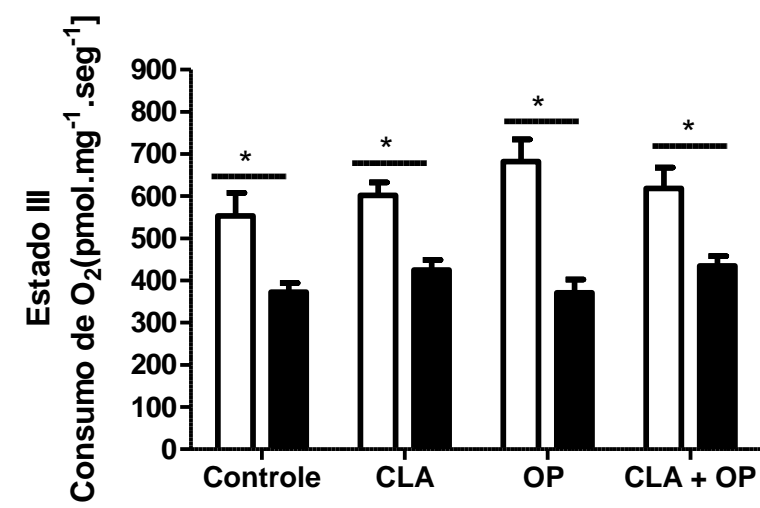

(D)

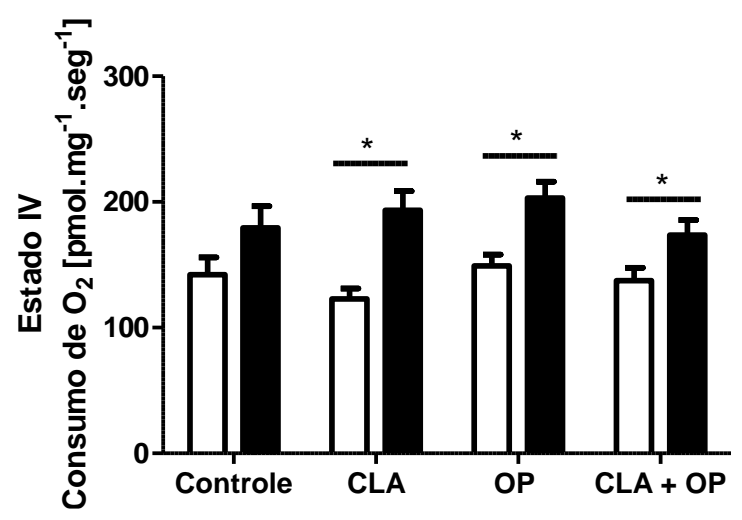


(E)

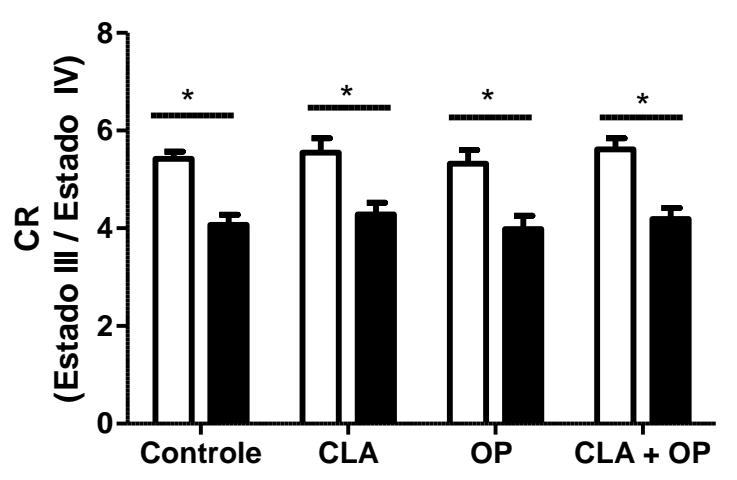

(G)

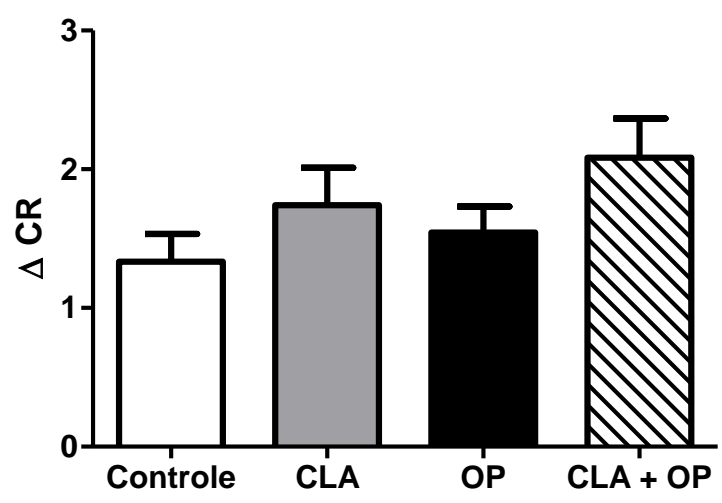

(I)

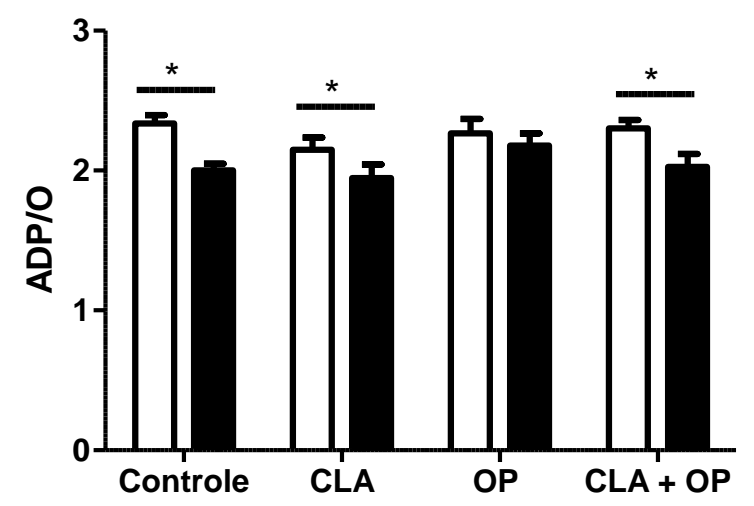

(F)

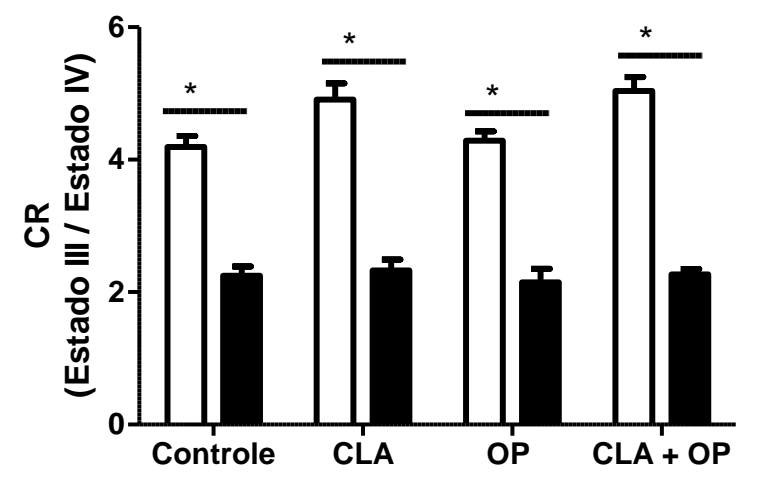

(H)

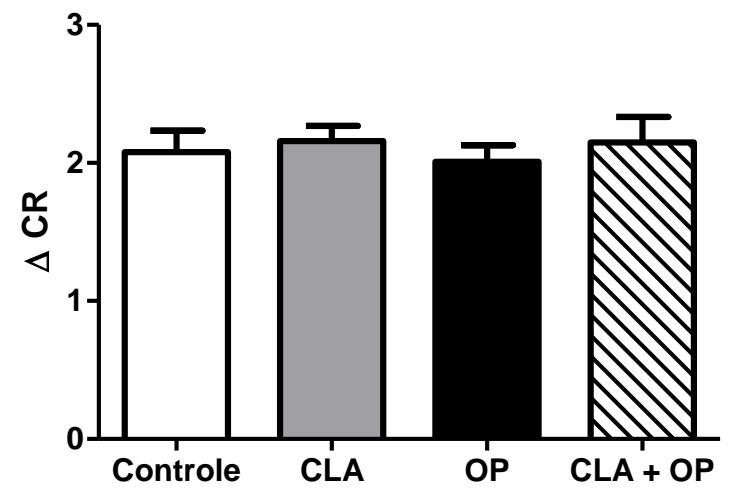

(J)

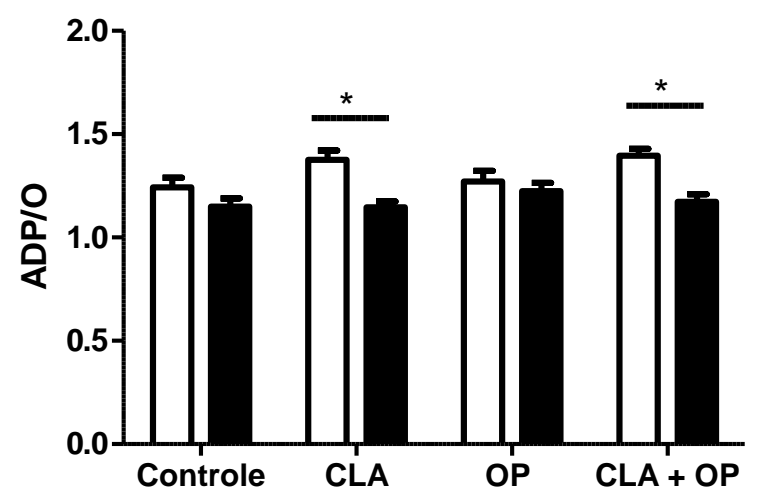


$(\mathrm{K})$

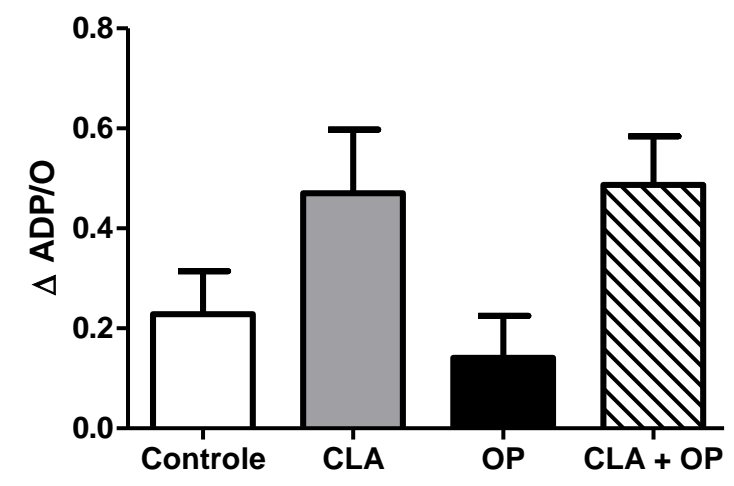

(L)

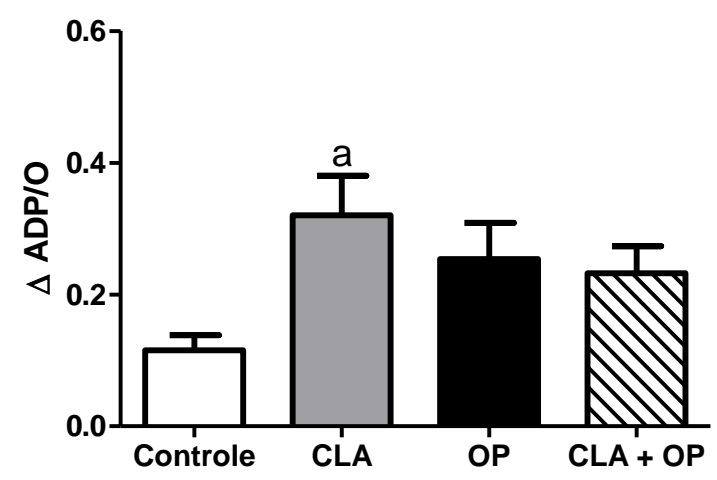

Figura 24: Taxas respiratórias de mitocôndrias isoladas $(0,5 \mathrm{mg} / \mathrm{mL})$ de fígado de camundongos tratados com CLA, OP, CLA + OP e controle, incubadas em meio de respiração na ausência (barras brancas) ou presença (barras pretas) de $2 \mu \mathrm{M}$ de LA. Velocidades de respiração de mitocôndrias energizadas com glutamato e malato no (A) estado III, e (C) estado IV, (E) CR (estado III/estado IV), (G) $\Delta \mathrm{CR}$, (I) razão ADP/O e (K) $\Delta$ ADP/O. Velocidades de respiração de mitocôndrias energizadas com succinato no (B) estado III, e (D) estado IV, (F)

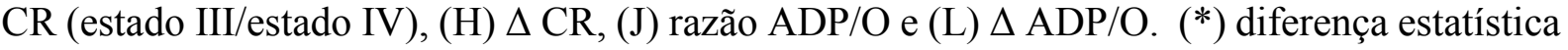
com $\mathrm{P}<0,05 .{ }^{a} \mathrm{P}<0,05$ vs controle. $\mathrm{n}=10-11$.

A oxidação de ácidos graxos é a principal via do metabolismo energético hepático e ocorre exclusivamente na mitocôndria. Para avaliar a eficiência das mitocôndrias em realizar $\beta$-oxidação nos camundongos tratados, as mitocôndrias isoladas foram incubadas em meio de respiração e receberam palmitoil-carnitina (PC) como substrato. O resultado foi obtido através do cálculo da razão entre a velocidade de oxidação de PC pela de glutamato. Observamos que houve um aumento da $\beta$-oxidação nos animais que receberam CLA ou OP sozinhos, ou em conjunto quando comparados aos animais controle (Figura 25).

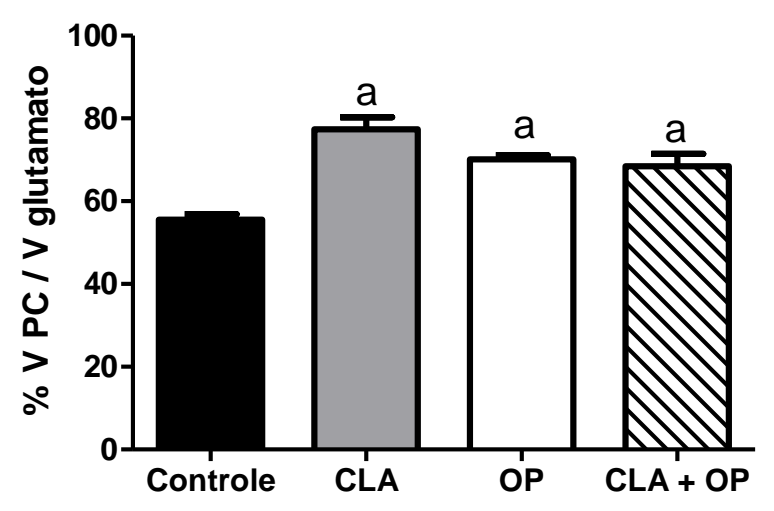

Figura 25: Taxa de $\beta$-oxidação de mitocôndrias isoladas de fígados de camundongos suplementados com CLA, OP, CLA + OP e controles. Média \pm EPM. ${ }^{\mathrm{a}} \mathrm{P}<0,05$ vs controle. 
Os resultados das respirações de biopsias estão representados sob razões entre os estados respiratórios. Isto porque obtivemos valores de respiração muito variados entre animais do mesmo grupo, o que pode ocorrer dependendo de variáveis como o estado alimentar do animal no momento da eutanásia e condições de estresse.

A figura 26A nos mostra a razão entre as velocidades de respiração com ADP e oligomicina. Esta razão é equivalente ao CR da mitocôndria isolada e nos indica o estado de acoplamento relacionado a capacidade de fosforilação oxidativa (GNAIGER, 2009, 2012). Admite-se que valores baixos de V ADP/ V oligomicina são indicativos de maior expressão e/ou atividade de UCPs. Em nossos resultados (Figura 26A) observamos que os animais dos grupos CLA e CLA+OP obtiveram valores menores em relação aos grupos controle e OP. Quando comparados aos respectivos grupos controle (controle ou OP), podemos afirmar que existe um menor acoplamento da respiração dos fígados dos animais que receberam somente CLA ( $v s$ controle) e dos animais que receberam CLA+OP ( $v s$ OP), mostrando o efeito desacoplador do CLA. Podemos ainda constatar que as mitocôndrias de fígado dos animais que foram suplementados somente com óleo de peixe possuem a respiração mais acoplada que o grupo CLA. Outra forma de avaliar o acoplamento é calculando a razão entre as velocidades de respiração com oligomicina e CCCP (Figura 26B), onde a V CCCP é dada pela capacidade máxima de transferência de elétrons pela CTE. Quanto maiores os valores de V oligomicina/V CCCP, maior é o desacoplamento (GNAIGER, 2012). Entretanto nesta medida não encontramos diferença estatística entre os grupos. Atribuímos estes diferentes resultados de acoplamento a quantidades insuficientes de CCCP que seriam necessárias para alcançar a máxima velocidade da CTE.

(A)

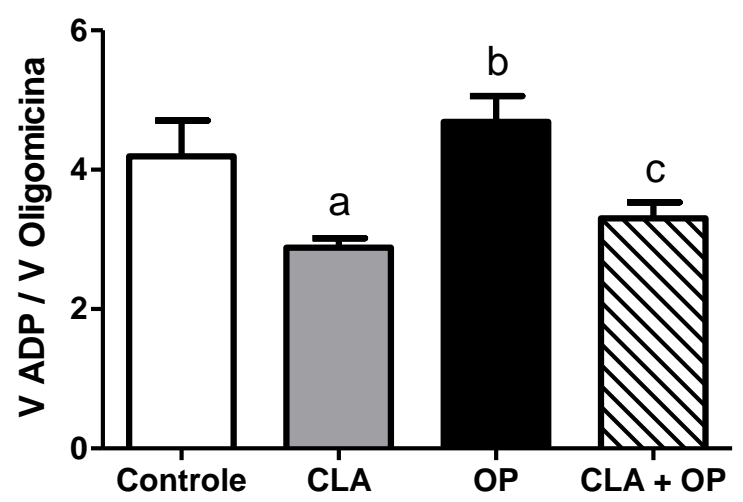

(B)

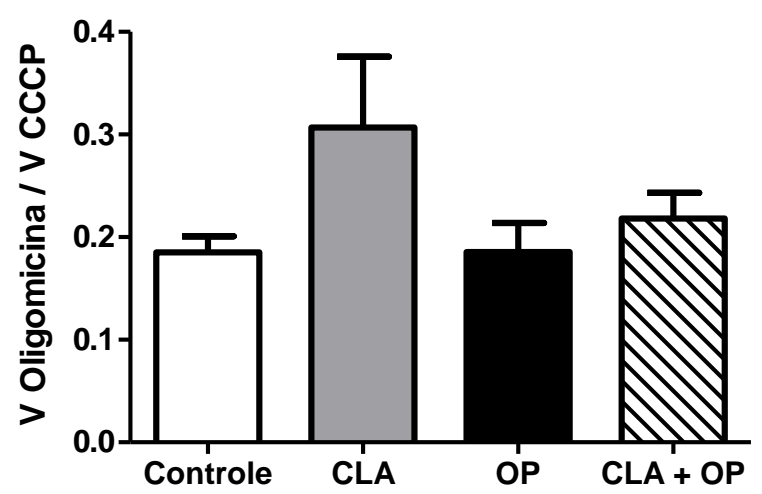

Figura 26: Razões entre as velocidades de ATP, oligomicina e CCCP obtidas na respiração de tecido hepático permeabilizado. (A) V ADP / V oligomicina; (B) V oligomicina / V CCCP. Média \pm EPM. ${ }^{\mathrm{a}} \mathrm{P}<0,05$ vs controle, ${ }^{\mathrm{b}} \mathrm{P}<0,05$ vs CLA, ${ }^{\mathrm{c}} \mathrm{P}<0,05$ vs OP. $\mathrm{N}=5-6$. 
Para verificar se o aumento na variação da ADP/O encontrado em mitocôndrias isoladas e as baixas V ADP/V oligomicina em biópsias hepáticas eram consequência de uma elevada expressão de UCPs, quantificamos os níveis de RNAm de UCP2, a isoforma mais abundante no fígado. Analisando a figura 27, constatamos que os animais que receberam somente CLA tinham maiores níveis de RNAm de UCP2 em relação ao controle. Os grupos OP e CLA+OP também apresentaram elevados valores em relação ao controle, porém não houve diferença significativa. Este resultado explica a elevada variação da ADP/O e V ADP/V oligomicina encontrados nas respirações dos animais tratados apenas com CLA.

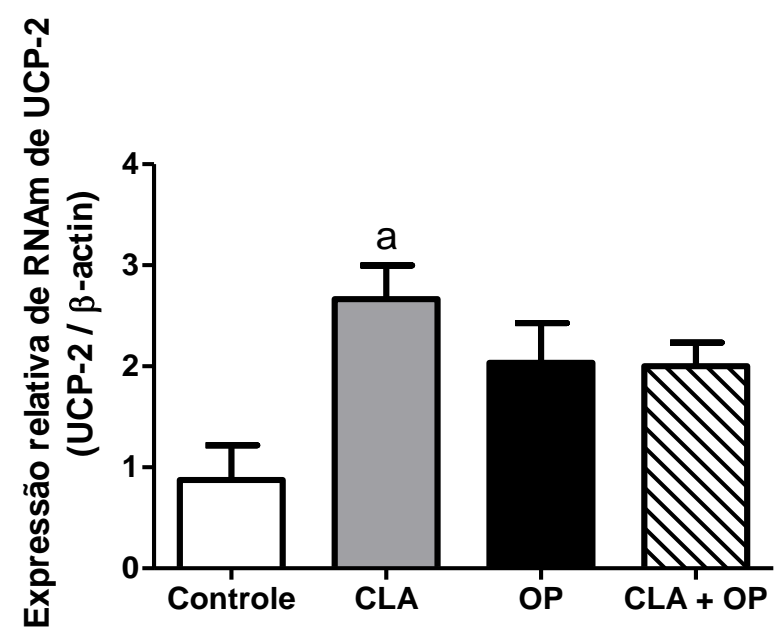

Figura 27: Quantificação de RNAm de UCP2 de fígado de camundongos suplementados com CLA, OP, CLA + OP e controle, determinada por real time PCR (RT-PCR) e normalizadas pela expressão do gene constitutivo $\beta$-actina. Média \pm EPM. ${ }^{a} \mathrm{P}<0,05$ vs controle.

Este resultado explica o aumento do metabolismo corporal nos animais que receberam somente CLA mas não esclarece o aumento do metabolismo corporal dos grupos OP e $\mathrm{CLA}+\mathrm{OP}$, encontrados por calorimetria indireta. Como o grupo suplementado com OP demonstrou alta eficiência da fosforilação oxidativa (Figura 26A), nós mensuramos a atividade da enzima citrato sintase (CS) no tecido hepático. A CS é exclusivamente localizada na matriz mitocondrial, porém é codificada no núcleo e sintetizada nos ribossomos citoplasmáticos. A CS é comumente usada como marcador enzimático quantitativo para o conteúdo das mitocôndrias intactas, cuja atividade relaciona-se com a massa de mitocôndrias (CIVITARESE et al., 2007; KUZNETSOV; LASSNIG; GNAIGER, 2010).

Através da análise da figura 28, podemos afirmar que os animais que receberam óleo de peixe sozinho e em conjunto com CLA apresentaram cerca de 4 vezes mais atividade da citrato sintase quando comparados aos grupos controle e CLA. Logo, pode-se atribuir o aumento do 
consumo de oxigênio do calorímetro ao maior número de mitocôndrias e, podemos relacionar também este fato com o aumento da velocidade de fosforilação do grupo que foi suplementado somente com óleo de peixe.

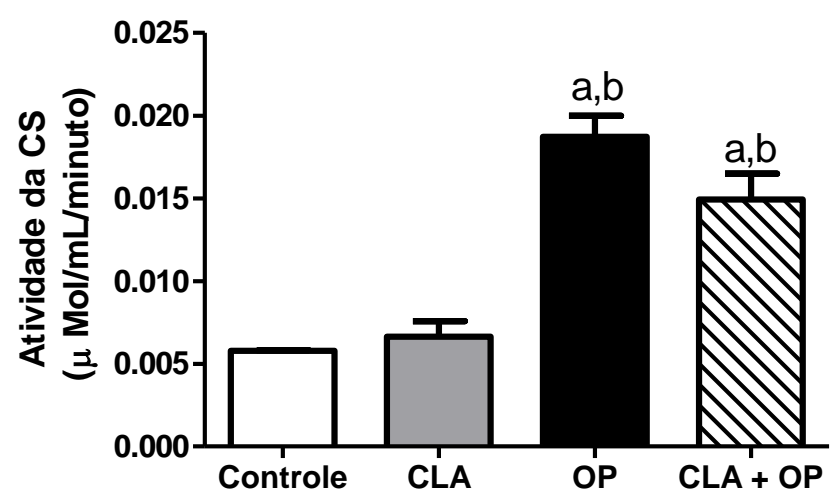

Figura 28: Atividade da citrato sintase em tecido hepático de camundongos suplementados com CLA, OP, CLA + OP e controle. Média \pm EPM. ${ }^{\mathrm{a}} \mathrm{P}<0,05$ vs controle, ${ }^{\mathrm{b}} \mathrm{P}<0,05$ vs CLA.

\subsubsection{Estresse oxidativo}

Estudos previamente realizados em nosso laboratório demonstraram que mitocôndrias isoladas de fígado de camundongos suplementados com CLA e energizadas com substratos de complexo I produzem mais EROs. (PEREIRA et al., 2012). No entanto quando administrado óleo de oliva em conjunto com CLA, o aumento na produção de EROs foi revertida (BARALDI et al., 2014). A fim de verificar se este resultado se repetia no tratamento com óleo de peixe, monitoramos durante 10 minutos a produção de $\mathrm{H}_{2} \mathrm{O}_{2}$, o produto da dismutação dos $\mathrm{O}_{2}{ }^{\bullet-}$ pela enzima superóxido dismutase em mitocôndrias isoladas do fígado na presença dos substratos glutamato/malato e succinato+rotenona e no tecido permeabilizado na presença de glutamato/malato. A figura 29A nos mostra somente um traçado representativo do ensaio da produção de EROs e nas figuras 29B e 29C estão os resultados apresentados como média \pm desvio padrão. Nas mitocôndrias energizadas com glutamato/malato (Figura 29B), demonstramos que a suplementação com CLA aumentou a produção de EROs, mas quando tratados em conjunto com o óleo de peixe, reverteu-se este aumento. No entanto não encontramos este perfil no grupo CLA+OP quando as mitocôndrias foram energizadas com succinato e rotenona (Figura 29C). O resultado da produção de EROs no tecido nos mostrou que o grupo que recebeu CLA juntamente com o óleo de peixe diminuiu a produção de EROs em relação ao grupo controle, mas não houve diferença quando comparado aos grupos que receberam os óleos isoladamente (Figura 30). 
(A)

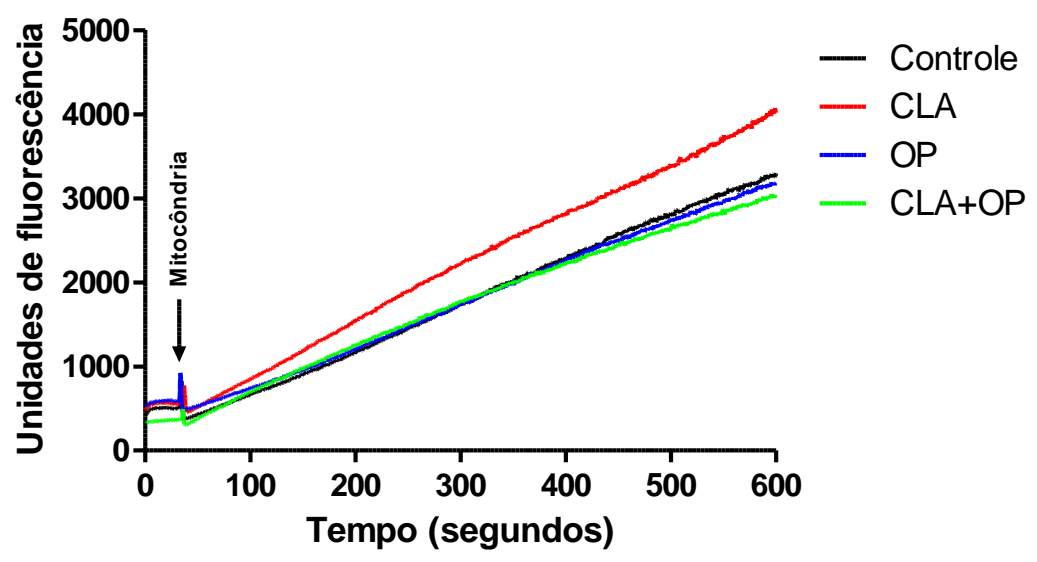

(B)

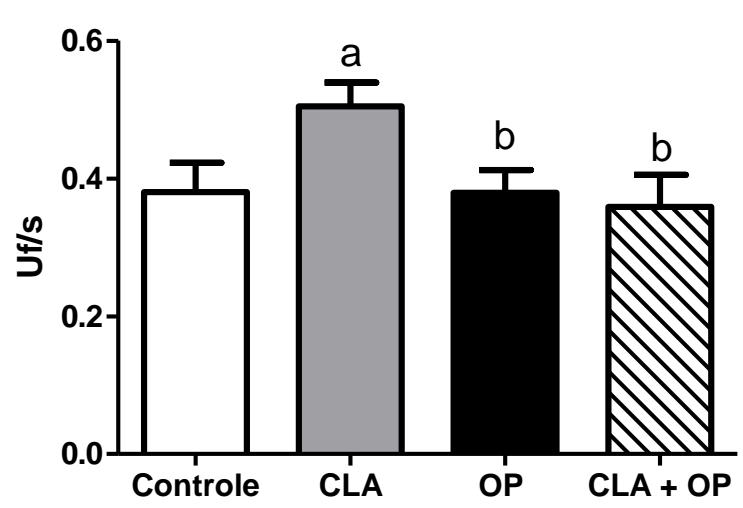

(C)

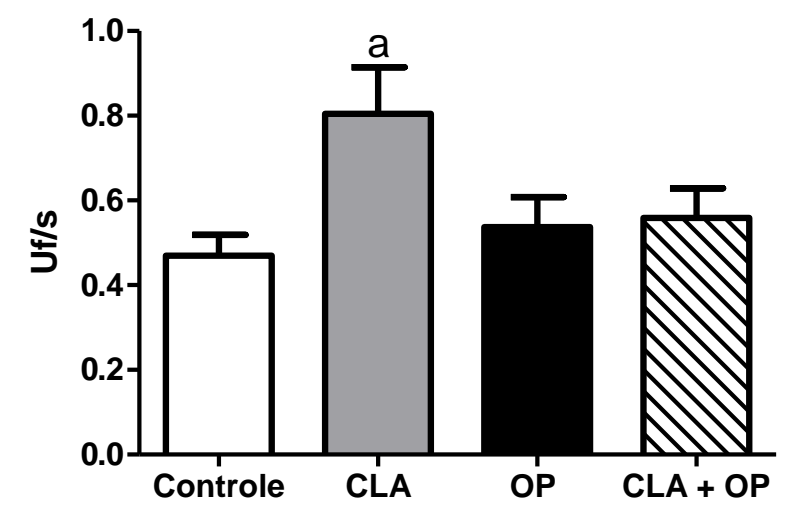

Figura 29: Geração de EROs em mitocôndrias isoladas de fígados de camundongos suplementados com CLA, OP, CLA + OP e controle. (A) Traçado representativo do ensaio da geração de EROs. (B) mitocôndrias energizadas com glutamato/malato e (C) succinato e rotenona. Média \pm EPM. ${ }^{a} \mathrm{P}<0,05$ vs controle, ${ }^{b} \mathrm{P}<0,05$ vs CLA.

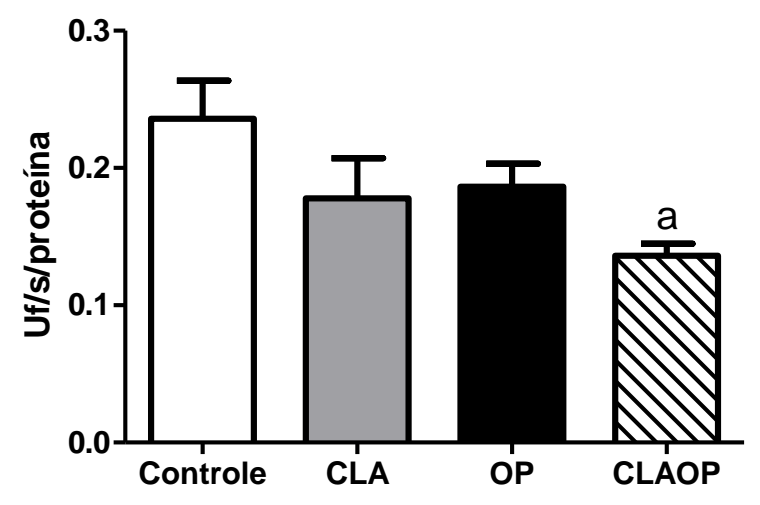

Figura 30: Geração de EROs no tecido hepático permeabilizado de camundongos suplementados com CLA, OP, CLA + OP e controle. Média \pm EPM. ${ }^{a} \mathrm{P}<0,05$ vs controle.

Espécies reativas de oxigênio oxidam lipídeos, proteínas e/ou DNA. Para verificar se o aumento da produção de EROs detectada no ensaio com mitocôndrias hepáticas isoladas dos 
camundongos suplementados com CLA, promovem danos oxidativos ao fígado, foram quantificados biomarcadores de estresse oxidativo como concentração de proteínas carboniladas e a razão entre glutationa reduzida e oxidada (GSH/GSSG).

A figura 31A nos mostra o resultado do ensaio de proteína carbonilada e a figura 31B do ensaio de GSH/GSSG. Demonstramos que os animais suplementados somente com CLA possuem maior concentração de proteína carbonilada que os animais dos demais grupos (Figura 31A). Atenta-se que o grupo de estudo (CLA+OP) obteve um resultado distinto dos outros 3 grupos (controle, CLA e OP). Verificamos, através da análise do sistema antioxidante da glutationa, que os animais dos grupos que receberam óleo de peixe (OP e CLA+OP) durante o tratamento, quando são comparados ao grupo que recebeu somente CLA, apresentaram maiores valores da razão GSH/GSSG (Figura 31B), ou seja, a quantidade de glutationa reduzida (GSH) é maior que a oxidada (GSSG).

(A)

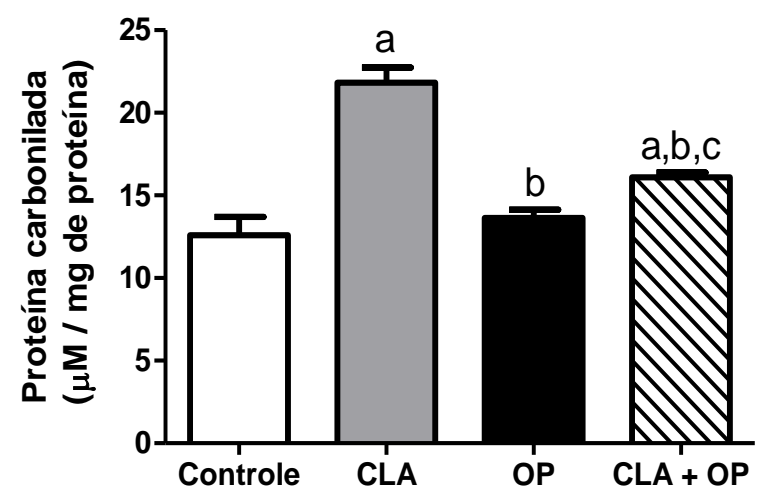

(B)

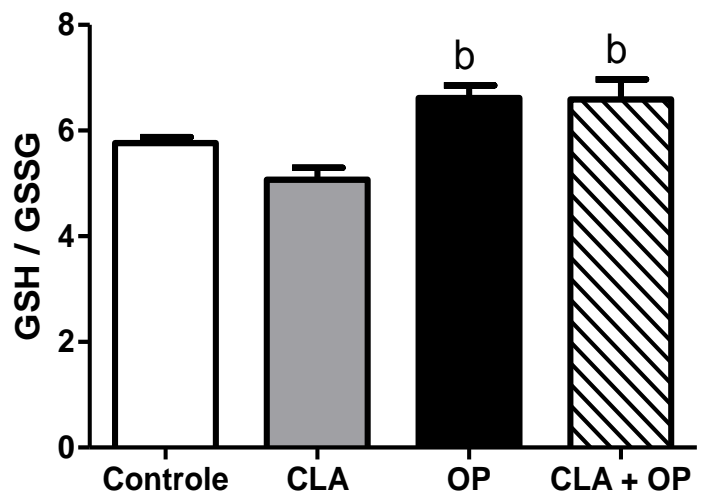

Figura 31: Parâmetros indicativos do estado redox do fígado de camundongos suplementados com CLA, OP, CLA + OP e controle. (A) concentração de proteínas carboniladas e (B) razão entre glutationa reduzida e oxidada. Média \pm EPM. ${ }^{a} \mathrm{P}<0,05$ vs controle, ${ }^{b} \mathrm{P}<0,05$ vs CLA, ${ }^{\mathrm{c}}$ $\mathrm{P}<0,05$ vs OP.

\subsubsection{Músculo sóleo}

O músculo esquelético é um tecido de intensa atividade metabólica e elevado gasto energético. O músculo sóleo é constituído por fibras de contração lenta, são altamente vascularizados e possuem um grande número de mitocôndrias, o que os confere grande capacidade oxidativa. Por isso monitoramos também o consumo de oxigênio em biópsias do músculo sóleo permeabilizadas. Da mesma forma que as respirações com tecido hepático, nós calculamos as razões: VADP/ V oligomicina (Figura 32A), V oligomicina/ V CCCP (Figura 
32B) e realizamos o ensaio de produção de EROs (Figura 33). Em nenhuma das análises encontramos diferença estatística entre os grupos e não podemos propor nenhuma tendência.

(a)

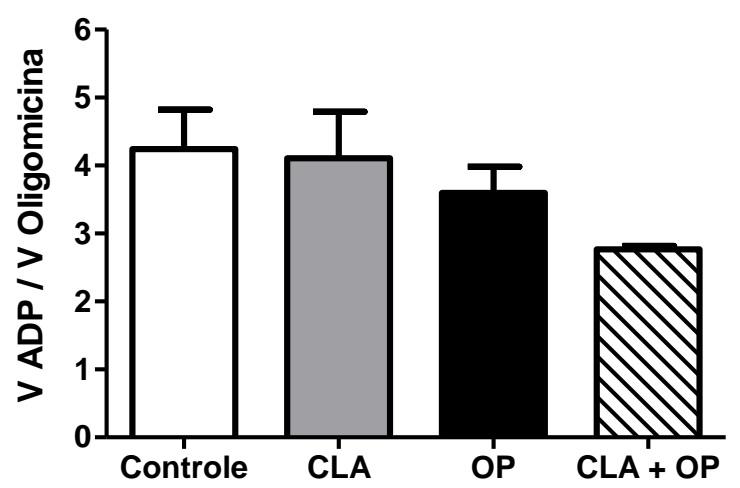

(b)

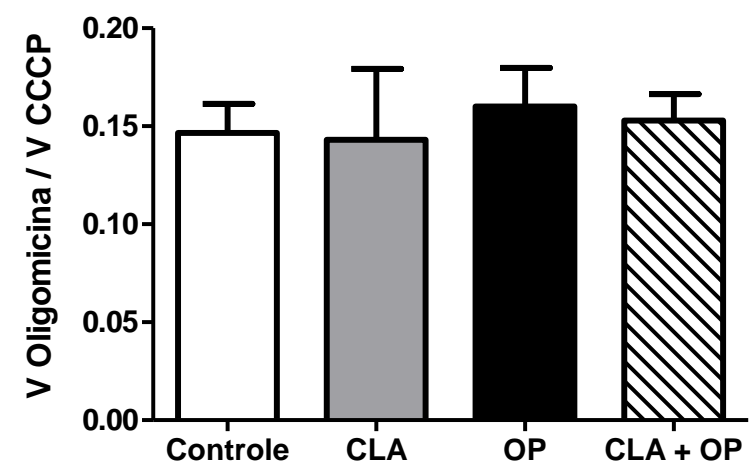

Figura 32: Razões entre as velocidades de ATP, oligomicina e CCCP obtidas na respiração de biópsia de sóleo permeabilizado. (A) V ADP / V oligomicina; (B) V oligomicina / V CCCP.

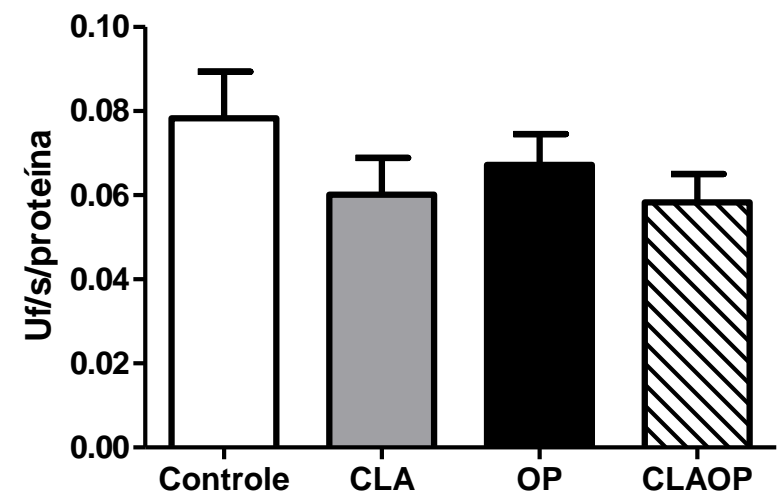

Figura 33: Geração de EROs no tecido muscular permeabilizado de camundongos suplementados com CLA, OP, CLA + OP e controle.

Assim como no fígado, nós quantificamos os níveis de RNAm de UCP2 (Figura 34) e determinamos a atividade da CS (Figura 35). Apesar de não ser a isoforma mais comum no músculo, surpreendentemente encontramos níveis de RNAm de UCP2 cerca de 4 vezes maior nos animais tratados com óleo de peixe sozinho (OP) e associado ao CLA (CLA+OP), quando comparados aos animais dos grupos controle e CLA. E encontramos também que a CS dos animais suplementados somente com óleo de peixe (OP) possui maior atividade entre todos os grupos. 


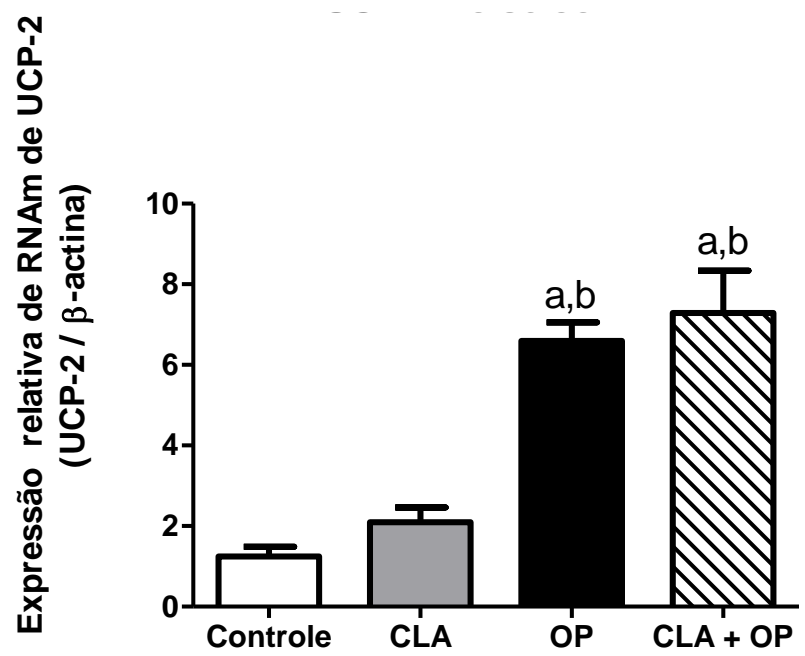

Figura 34: Quantificação dos níveis de RNAm de UCP2 no sóleo de camundongos suplementados com CLA, OP, CLA + OP e controle, determinada por real time PCR (RT-PCR) e normalizadas pela expressão do gene constitutivo $\beta$-actina. Média \pm EPM. ${ }^{a} \mathrm{P}<0,05$ vs controle, ${ }^{\mathrm{b}} \mathrm{P}<0,05$ vs CLA.

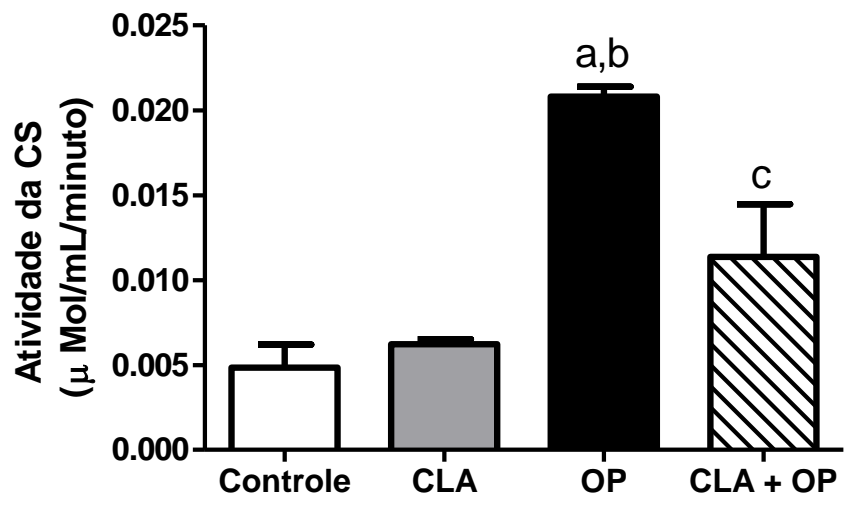

Figura 35: Atividade da citrato sintase em do sóleo de camundongos suplementados com CLA, $\mathrm{OP}, \mathrm{CLA}+\mathrm{OP}$ e controle. Média \pm EPM. ${ }^{\mathrm{a}} \mathrm{P}<0,05$ vs controle, ${ }^{\mathrm{b}} \mathrm{P}<0,05$ vs CLA, ${ }^{\mathrm{c}} \mathrm{P}<0,05$ OP.. 
Devido a elevada atividade da CS no sóleo dos animais do grupo OP, nós quantificamos também os níveis de RNAm de PGC1- $\alpha$. Analisando a figura 36 podemos afirmar que os animais que receberam óleo de peixe (OP e CLA+OP) durante o tratamento possuíam níveis elevados de PGC1- $\alpha$ quando comparados aos grupos controle e CLA, mas entre si não houve diferença significativa. Diante destes resultados podemos atestar que o óleo de peixe promove biogênese mitocondrial no músculo sóleo e, devido ao maior número de mitocôndrias também há maior número de UCPs.

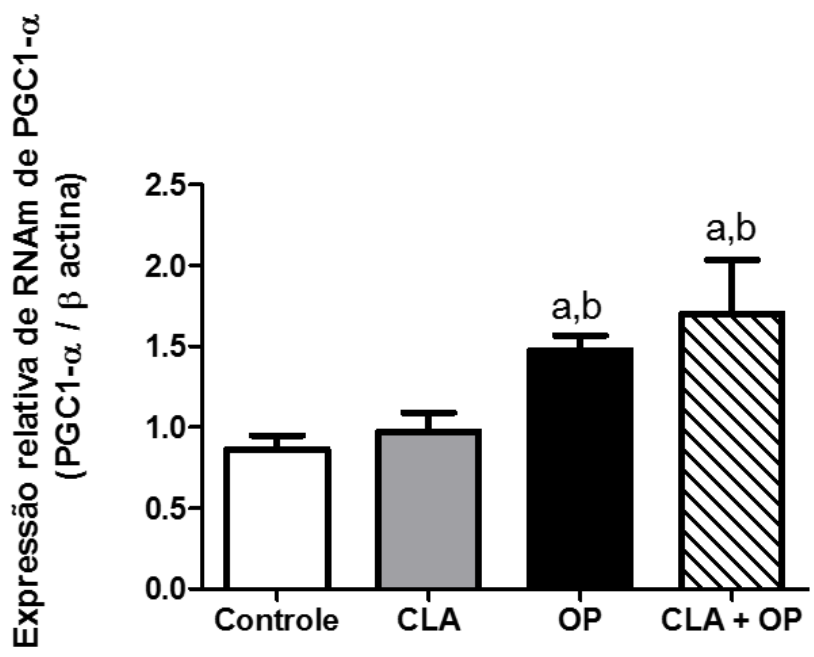

Figura 36: Quantificação de RNAm de PGC1- $\alpha$ no sóleo de camundongos suplementados com CLA, OP, CLA + OP e controle, determinada por real time PCR (RT-PCR) e normalizadas pela expressão do gene constitutivo $\beta$-actina. Média \pm EPM. ${ }^{a} \mathrm{P}<0,05$ vs controle, ${ }^{\mathrm{b}} \mathrm{P}<0,05$ vs CLA.

\subsubsection{Hipocampo}

O resultado do RQ obtido na calorimetria indireta nos indica que o substrato oxidativo principal utilizado pelos animais que receberam óleo de peixe (OP e CLA+OP) é a glicose. Sabendo que o óleo de peixe tem sua ação concentrada no hipocampo e que o cérebro utiliza a glicose como principal fonte energética, nós analisamos os efeitos do CLA associado ao óleo de peixe no hipocampo dos camundongos tratados. Também analisamos a produção de EROs no tecido, pois as espécies reativas de oxigênio são prejudiciais ao tecido nervoso e são consideradas uma das principais causas de doenças neurodegererativas.

Realizamos a respiração dos hipocampos permeabilizados e não encontramos diferenças entre as razões $\mathrm{V}$ ADP/V oligomicina (Figura 37A) mas os resultados obtidos da razão $\mathrm{V}$ oligomicina/VCCCP (Figura 37B) nos mostra que os animais que receberam CLA durante o tratamento (CLA e CLA+OP) possuíam valores maiores de $\mathrm{V}$ oligomicina/ VCCCP que os 
animais do grupo controle e os que receberam somente óleo de peixe. Nestes mesmos animais observamos a redução da produção de EROs em relação aos animais do grupo controle (Figura 38). Estes dois resultados nos sugerem maior expressão de UCPs, pois sabe-se que esta proteína, além de desacopladora, no tecido nervoso, ela exerce um papel protetor contra estresse oxidativo.

(A)

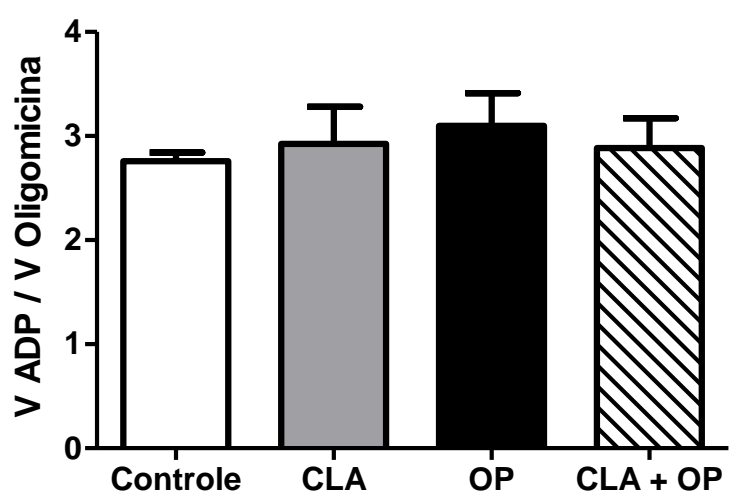

(B)

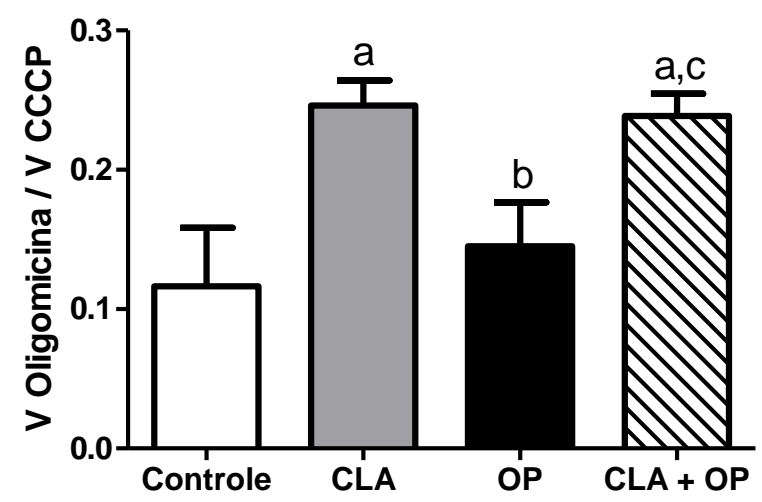

Figura 33: Razões entre as velocidades de ATP, oligomicina e CCCP obtidas na respiração de biópsia de hipocampo permeabilizado. (A) V ADP / V oligomicina; (B) V oligomicina / V CCCP. Média \pm EPM. ${ }^{a} \mathrm{P}<0,05$ vs controle, ${ }^{\mathrm{b}} \mathrm{P}<0,05$ vs CLA, ${ }^{\mathrm{c}} \mathrm{P}<0,05$ vs OP.

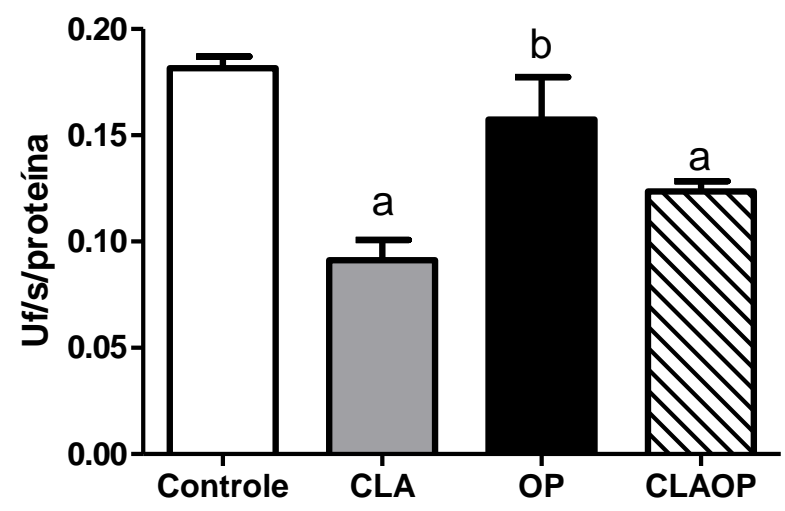

Figura 38: Geração de EROs em tecido hipocampal permeabilizado de camundongos tratados com CLA, OP, CLA + OP e controle. Média \pm EPM. ${ }^{\mathrm{a}} \mathrm{P}<0,05$ vs controle, ${ }^{\mathrm{b}} \mathrm{P}<0,05$ vs CLA.

Considerando os resultados da respiração e da produção de EROs, nós mensuramos os níveis de RNAm de UCP5, que é a isoforma presente no cérebro. A figura 39A mostra que não obtivemos resultados com $\mathrm{P}<0,05$, mas nota-se que os animais que receberam CLA alcançaram maiores valores quando comparados aos grupos controle, OP e CLA+OP.

Assim como nos outros tecidos analisados, nos dosamos também a atividade da CS e observamos que o grupo CLA+OP possui maior atividade enzimática somente quando comparado ao grupo controle (Figura 39B) 
(A)

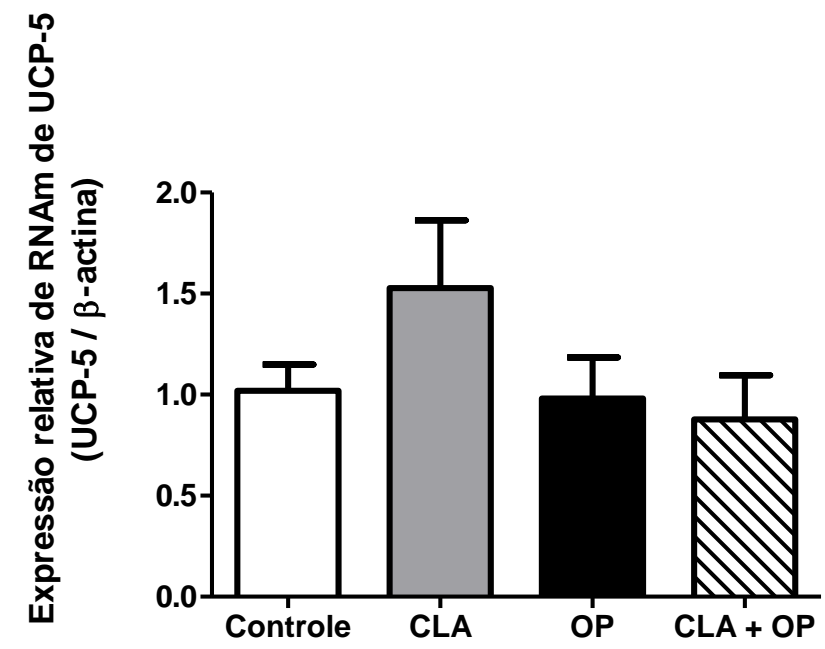

(B)

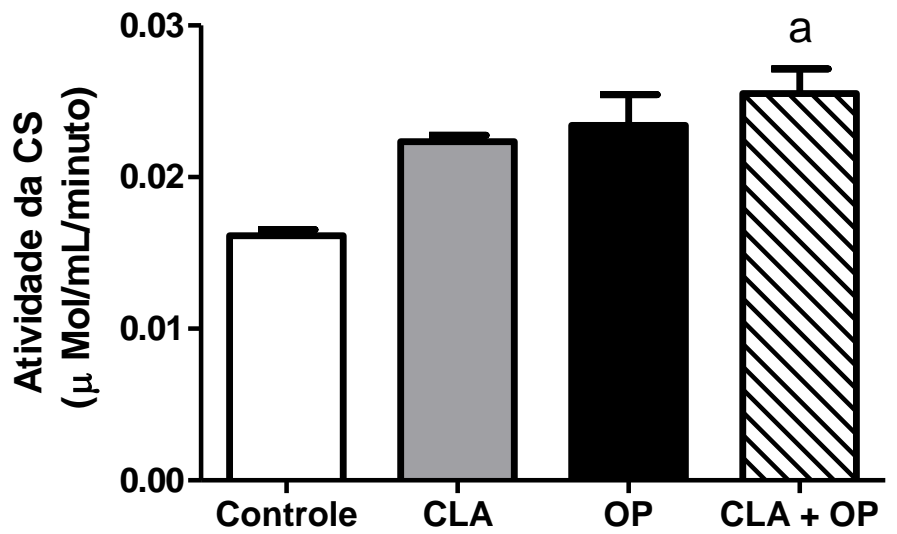

Figura 39: (A) Quantificação de RNAm de UCP5 determinada por real time PCR (RT-PCR) e normalizadas pela expressão do gene constitutivo $\beta$-actina e (B) atividade da citrato sintase no hipocampo de camundongos suplementados com CLA, OP, CLA + OP e controle. Média \pm EPM. ${ }^{a} \mathrm{P}<0,05$ vs controle. 


\section{Q Discussão}




\section{DISCUSSÃO}

\section{Metabolismo corporal}

A energia para suportar os processos vitais é obtida pela oxidação dos nutrientes contidos nos alimentos ingeridos. Esse processo consome oxigênio e produz água, gás carbônico, energia química (armazenada nas ligações fosfato do ATP) e calor que é dissipado para o meio ambiente. Os parâmetros analisados pela calorimetria indireta estão diretamente relacionados a este cenário. Conseguimos obter valores de $\mathrm{EE}, \mathrm{VO}_{2}$ e $\mathrm{VCO}_{2}$ e inclusive a relação entre eles que chamamos de quociente respiratório (RQ) e pode ser empregada para conhecer o tipo de substrato que está sendo oxidado pelo indivíduo em estudo (EVEN; NADKARNI, 2012). A partir de cálculos matemáticos foi padronizado que para cada tipo de substrato existem valores específicos para RQ. São adotados os valores de 0,7, 0,8 e 1,0 para a oxidação de gorduras, proteínas e carboidratos, respectivamente (ARCH et al., 2006). Ao analisarmos os resultados do calorímetro observamos que os grupos dos animais que recebiam óleo de peixe (OP e CLA+OP) obtiveram valores próximos a 1,0, que de acordo com os valores padrões de RQ indica a predominância de oxidação de carboidratos. Ao passo que o grupo que recebeu somente CLA alcançou valores próximos de 0,7 indicando a prevalência de oxidação de gorduras nestes animais. Num estudo recente, KIM et al. (2015) utilizou a calorimetria indireta para analisar os efeitos do óleo de peixe sobre o metabolismo energético. Eles observaram que os animais que receberam o AG apresentaram maior consumo de oxigênio e gasto energético em relação aos animais controle. Por outro lado, WEST et al. (2000) ao tratar camundongos $\mathrm{AKR} / \mathrm{J}$ com $1 \%$ de uma mistura de isômeros de CLA por 5 semanas e monitorar parâmetros do metabolismo corporal, não perceberam redução ou ganho de peso, mas relataram uma considerável diminuição do tecido adiposo e aumento do gasto energético nos animais que receberam CLA. A literatura nos mostra que isoladamente estes óleos aumentam o metabolismo. Nosso trabalho confirmou estes achados e mostrou de forma inédita que quando administrados em conjunto os efeitos isolados desses dois óleos sobre o metabolismo corporal não se somam.

Utilizando o calorímetro analisamos também a atividade locomotora e o levantamento dos animais. Sabemos que o óleo de peixe, em roedores, é muito estudado em relação parâmetros comportamentais como moderador de ansiedade (VINOT et al., 2011) e hiperatividade (CHALON et al., 1998). Muitos trabalhos descrevem que animais tratados com óleo de peixe têm diminuída atividade locomotora, um parâmetro que pode ser relacionado a 
diminuição da ansiedade. Em 2011, VINOT e colaboradores mostraram que os animais tratados com óleo de peixe tiveram redução em $31 \%$ da sua atividade locomotora em relação ao grupo controle. Da mesma forma, BENJAMIN DREW ROCKETTA (2012) verificou que camundongos C57bl6 submetidos a uma dieta com altas concentrações de ácidos graxos ômega3 reduziram a movimentação horizontal e vertical, fato igualmente encontrado nos resultados deste trabalho. Por outro lado, OHNUKI et al., (2001b) demonstraram que em animais que receberam uma única dose de CLA houve um aumento na atividade locomotora em relação à animais que receberam ácido linoleico. Seu estudo também demonstrou que houve um aumento na concentração de adrenalina e noradrenalina circulantes nestes animais o que pode justificar o aumento da movimentação dos animais suplementados com CLA em nosso trabalho. Ainda que a metodologia utilizada em nosso estudo foi um tratamento de 60 dias nossos resultados são condizentes com o trabalho do autor citado acima. Possivelmente o óleo de peixe exerça uma ação atenuadora nos efeitos do CLA quando se diz respeito a atividades comportamentais. No entanto, para afirmar certamente este fato, é necessário um estudo aprofundado nesta área.

Um dos efeitos desfavoráveis do CLA é a indução da resistência à insulina (ZHOU et al., 2008; ALMEIDA et al., 2015). Quando analisamos a influência da suplementação do óleo de peixe e do CLA sobre o metabolismo da glicose, observamos que os animais que foram suplementados com CLA (CLA e CLA+OP) apresentaram dificuldades na captação da glicose e resistência à insulina. $\mathrm{O}$ tratamento em conjunto com o óleo de peixe (CLA+OP) não reverteu essa condição causada pela suplementação com CLA. Na literatura há indícios de que o óleo de peixe melhora a sensibilidade à insulina, porém o mecanismo ainda não é bem entendido. Há uma hipótese de que os efeitos de aumento a sensibilização a insulina in vivo do óleo de peixe se dão através da supressão da inflamação via GPR120 (proteína G acoplada ao receptor 120). Em macrófagos M1 pró-inflamatórios no tecido adiposo, os ácidos graxos EPA e DHA ativam o GPR120, que por sua vez atenua a resposta inflamatória e recruta macrófagos antiinflamatórios M2 e restabelecem a secreção de interleucina-10 que melhora a sensibilidade à insulina (OH et al., 2010, 2014; SALTIEL, 2010; IWASE; KAMEI; TAKEDA-MORISHITA, 2015). Sabe-se que uma das causas/consequências da obesidade é a inflamação no tecido adiposo (WELLEN; HOTAMISLIGIL, 2003; FANTUZZI, 2005) e também que obesidade e resistência à insulina estão diretamente ligados. Em nosso trabalho, a resistência à insulina foi induzida por CLA, onde o isômero trans-10, cis-12 leva a inflamação induzindo a expressão do fator de necrose tumoral- $\alpha(\mathrm{TNF}-\alpha)$ e interleucina 6 , associada com a ativação do fator nuclear 
$\kappa B(N F-\kappa B)$ (BARALDI et al., 2016). Talvez o motivo pelo qual o óleo de peixe não tenha revertido a resistência à insulina seria o fato de que as vias de ação de cada óleo são diferentes.

\section{Fígado}

As mitocôndrias desempenham um papel central no metabolismo de células eucarióticas, contribuindo para a produção de energia (ATP) e metabolismo intermediário. Por outro lado, o fígado é o principal órgão de controle metabólico nos mamíferos. A fim de analisar o metabolismo energético, avaliamos os efeitos do óleo de peixe e do CLA sobre mitocôndrias isoladas de fígado e o tecido hepático em si. Verificamos que a presença dos dois óleos na dieta aumenta a $\beta$-oxidação (grupos CLA, OP e CLA+OP). No fígado, já foi relatado na literatura o aumento da $\beta$-oxidação pelos dois óleos isolados, sendo o CLA responsável por aumentar a $\beta$ oxidação através do aumento da atividade da CPT (RAHMAN et al., 2001; KOBA et al., 2002) e o óleo de peixe estimula a $\beta$-oxidação nos peroxissomos (YAMAZAKI; SHEN; SCHADE, 1987; MADSEN et al., 1998).

Um estudo publicado anteriormente por nosso laboratório, demonstrou em mitocôndrias isoladas de fígado de camundongos tratados com CLA, o aumento da produção de EROS através de reações de oxido-redução envolvendo $\mathrm{NAD}^{+} / \mathrm{NADH}$ no ciclo de Krebs (PEREIRA et al., 2012). O mesmo resultado foi encontrado neste trabalho nas mitocôndrias energizadas com substrato de complexo I, que consequentemente consumiu GSH e elevou a oxidação celular. Nossos resultados mostraram ainda que a suplementação simultânea com o óleo de peixe reverte a produção de EROs induzida pelo CLA e, parcialmente, os danos celulares. Este resultado evidencia o efeito antioxidante do óleo de peixe, já mostrado em fígados por TAKAHASHI et al., (2002). Os mesmos resultados não foram encontrados no ensaio de produção de EROs com a biópsia de fígado e atribuímos isso ao método utilizado.

A metodologia escolhida para verificar a produção das EROs detecta a fluorescência de um produto (resorufina) formado a partir da oxidação do Amplex ${ }^{\circledR} \operatorname{Red}$ pelo $\mathrm{H}_{2} \mathrm{O}_{2}$ na presença de HRP (ZHOU et al., 1997). Em mitocôndrias isoladas, este $\mathrm{H}_{2} \mathrm{O}_{2}$ é detectado quando atravessa as membranas da organela e se encontra no meio de reação. Embora este método seja considerado sensível e de confiança, em tecidos devemos considerar que existem enzimas citoplasmáticas, como catalases e peroxidases, que utilizam $\mathrm{H}_{2} \mathrm{O}_{2}$ como substrato. Desse modo, sendo o fígado um órgão com intensa atividade destas enzimas, a detecção das EROs no tecido hepático, em nossos resultados, pode ter sido equivocada, uma vez que o $\mathrm{H}_{2} \mathrm{O}_{2}$ detectado no meio de reação pode não ser o produzido realmente pela mitocôndria. 
Os animais que receberam a suplementação com CLA mostraram um aumento da atividade de proteínas desacopladoras e, este efeito foi mantido mesmo quando administrado em conjunto com o óleo de peixe. A análise de expressão de UCP2 nos revelou que os animais tratados com somente CLA ou óleo de peixe (porém não significativo) aumentaram a expressão destas proteínas quando comparados ao controle. Os animais que foram suplementados com os dois óleos apresentaram mesmo nível de expressão que os camundongos tratados com óleo de peixe, porém um nível menor que os tratados com CLA. Um trabalho publicado recentemente por nosso laboratório (BARALDI et al., 2016) mostrou que a suplementação com CLA regula a expressão de UCP2 pelo aumento da produção de EROs. Aqui, nós mostramos que o óleo de peixe reverteu a produção de EROs induzida pelo CLA. Provavelmente, a diminuição da expressão de UCP2 pelos animais CLA+OP se deve a este fato.

Em 2005, IDE mostrou a diminuição da expressão de UCP no fígado de camundongos tratados com CLA e óleo de peixe em diferentes concentrações, ainda observou-se que quanto maior a concentração do óleo de peixe, mais diminuía a expressão de UCPs. Por outro lado, foi encontrado nos animais que receberam óleo de peixe um aumento da atividade da enzima citrato sintase, a qual indica o conteúdo mitocondrial (IDE, 2005). Em 2002, NESCHEN et al. também encontrou um aumento de duas vezes mais que o controle do conteúdo mitocondrial em fígados de camundongos tratados com óleo de peixe (NESCHEN et al., 2002).

\section{Músculo sóleo}

Nossos resultados referentes à produção de EROs no tecido muscular permeabilizado não nos fornece informações concretas sobre os efeitos do CLA e do óleo de peixe no sóleo dos camundongos pois não encontramos diferenças entre os grupos. No entanto, em mitocôndrias musculares isoladas do quadríceps de camundongos tratados com uma dieta hiperlipídica suplementada com isômeros c9,t11 e t10,c12 do CLA isolados ou mistos, RAHMAN et al. (2009) encontraram um aumento da produção de $\mathrm{H}_{2} \mathrm{O}_{2}$ em todos os animais que receberam CLA bem como aumento na atividade da catalase nos tecidos musculares dos animais que foram tratados com a mistura de isômeros e somente com t10,c12 (RAHMAN et al., 2009). Semelhantemente, em 2013, LANZA et al. também observaram um aumento da produção de $\mathrm{H}_{2} \mathrm{O}_{2}$ em mitocôndrias isoladas do quadríceps de camundongos tratados com dieta hiperlipídica e em conjunto com óleo de peixe, o qual não exerceu efeito protetor sob a produção de $\mathrm{H}_{2} \mathrm{O}_{2}$. Da mesma forma que em nosso trabalho, também não constataram diferenças na produção de $\mathrm{H}_{2} \mathrm{O}_{2}$ em fibras permeablizadas. Segundo o autor, as fibras permeabilizadas possuem antioxidantes endógenos que captam $\mathrm{o}_{2} \mathrm{H}_{2}$ produzido, pois verificaram um aumento na 
atividade da catalase nas fibras musculares retiradas dos animais que foram tratados com dieta hiperlipídica na ausência e na presença do óleo de peixe. Isto explicaria a análise do aumento da produção de $\mathrm{H}_{2} \mathrm{O}_{2}$ em mitocôndrias isoladas e não em fibras permeabilizadas e conclui também que o óleo de peixe não influencia a produção de $\mathrm{H}_{2} \mathrm{O}_{2}$ bem como a atividade de antioxidantes endógenos (LANZA et al., 2013).

Nos ensaios de respiração realizados com biópsias musculares não encontramos diferenças entre os quatro grupos em nenhum dos parâmetros calculados (V ADP/ V Oligomicina e V Oligomicina / V CCCP) para avaliar o metabolismo energético. Em 2012. VAUGHAN et al., observaram algumas mudanças em células humanas de rabdomiosarcoma tratadas com duas concentrações diferentes de ômega-3 e CLA isolados por 24 e 48 horas. As células tratadas com ômega-3 aumentaram significativamente a capacidade glicolítica em comparação ao controle sem suprimir o metabolismo oxidativo sugerindo que ômega-3 aumentou o metabolismo total e elevou significativamente o consumo de oxigênio basal, uma medida de oxidação de ácidos graxos. Ainda neste trabalho, foram encontrados, nas células que receberam o tratamento com óleo de peixe, níveis altos de mRNA de PGC-1 $\alpha$ (VAUGHAN et al., 2012). O mesmo resultado foi encontrado por PHILP et al., (2015), porém em músculos sóleos de camundongos tratados com dieta hiperlipídica associada ao óleo de peixe (PHILP et al., 2015). O nosso resultado sobre a expressão de PGC-1 $\alpha$ no músculo sóleo também mostrou que os animais que foram suplementados com óleo de peixe (OP e CLA+OP) apresentaram maiores níveis mRNA para esta proteína. Além disso, mostra que a suplementação conjunta com CLA não interferiu nos efeitos do óleo de peixe sobre a expressão do PGC-1 $\alpha$, que é um co-ativador transcricional chave para a biogênese mitocondrial (WU et al., 1999) . Nos grupos OP e CLA+OP também foram encontrados níveis altos de mRNA para UCP2. Sabe-se que no fígado o CLA induz fortemente a expressão de UCP2 (PEREIRA et al., 2012). No músculo gastrocnêmio de ratos diabéticos RYDER et al., (2001) encontraram que a suplementação com o isômero c9,t11 do CLA aumentou a expressão de UCP2, no entanto EALEY; EL-SOHEMY; ARCHER (2002) não encontraram nenhuma diferença na expressão de UCP2 tanto em ratos como em camundongos normais e tratados com uma mistura de isômeros do CLA. Assim como EALEY; EL-SOHEMY; ARCHER (2002) não encontramos modificação nos níveis de UCP2 nos animais tratados apenas com CLA, mas um grande aumento foi encontrado quando CLA foi administrado junto com o óleo de peixe, demonstrando o efeito predominante do óleo de peixe. Os resultados da expressão de PGC-1 $\alpha$ e UCP2 unidos aos resultados da atividade da enzima citrato sintase a qual reflete a densidade mitocondrial, onde os animais que foram 
suplementados com óleo de peixe obtiveram maiores valores, nos sugerem que o óleo de peixe promove a biogênese mitocondrial no músculo sóleo.

\section{Hipocampo}

A expressão e descrição da UCP5 foi feita pela primeira vez em 1998 por SANCHIS et al. sob o nome de BMCP1 (brain mitochondrial carrier protein-1) que detectou alta expressão destas proteínas em células nervosas. Esses autores mostraram uma forte atividade desacopladora da respiração e, com base na sequência de aminoácidos verificou-se que ela pertencia à superfamília dos transportadores mitocondriais e homóloga às UCPs (SANCHIS et al., 1998). Até o momento não foi encontrado na literatura nenhum trabalho sobre a suplementação com CLA ou óleo de peixe relacionados à expressão de UCP5 no cérebro. Em nosso trabalho, mostramos pela primeira vez que a suplementação da dieta com CLA sozinho aumenta a os níveis de mRNA de UCP5, apesar de não ser estatisticamente diferente, para os sistemas biológicos podem representar grandes alterações metabólicas. Reforçando este achado, nossos resultados de respiração mostram que as biópsias de hipocampo de animais suplementados com CLA ou CLA+OP possuem respiração mais desacoplada. Dessa forma, a não detecção de UCP5 nos animais CLA+OP nos sugere que estejam envolvidas outras isoformas de UCPs, provavelmente induzidas pelo óleo de peixe em conjunto ao CLA.

Quando analisamos a produção de EROs no hipocampo, encontramos que os animais que foram suplementados com CLA (CLA e CLA+OP) tiveram menor produção de EROs quando comparados ao controle. Em 2001, KIM-HAN et al. encontrou em células o córtex de camundongos que a expressão de UCP5 diminuía a produção de EROs e atribuiu à proteína o papel de controlar essa produção (KIM-HAN et al., 2001). Isto faz com que a UCP5 se torne uma importante proteína para proteção contra os danos oxidativos no cérebro causados pela excessiva produção de EROs. Mediante nossos resultados, sugerimos a presença de UCP5 nos animais tratados com CLA e mostramos que a suplementação com óleo de peixe e CLA em conjunto aumenta o número de mitocôndrias no hipocampo, já que os óleos sozinhos, apesar de não apresentarem diferença estatística, também aumentam sutilmente o conteúdo mitocondrial. Até o momento não foram encontrados estudos relacionando CLA e óleo de peixe com biogênese no cérebro, mas em células musculares em cultura já foi demonstrado o efeito biogênico do CLA (KIM; PARK, 2015) e do óleo de peixe (VAUGHAN et al., 2012). Estes resultados indicam os efeitos somatórios do CLA e o óleo de peixe no hipocampo dos animais suplementados. 
Bonclusones 


\section{CONCLUSÕES}

\section{In vivo}

As suplementações da dieta com CLA e óleo de peixe, isoladamente ou em conjunto, promovem aumento do metabolismo corporal, sem efeito somatório, sendo o óleo de peixe mais potente que o CLA. A suplementação com CLA aumenta a queima de gordura, tem tendência a diminuir a gordura corporal (porém não significativo), porém gera prejuízo no metabolismo da glicose circulante. A suplementação com óleo de peixe por si só não promove nenhum efeito no metabolismo de lipídeos ou glicose, porém diminui a frequência de movimentação dos animais. A suplementação conjunta de CLA e óleo de peixe mantém o prejuízo no metabolismo de glicose, a reduzida movimentação dos animais, e tem tendência a diminuir a gordura corporal (porém não significativo), porém reverte o aumento da queima de ácidos graxos. Esses resultados indicam que o efeito do óleo de peixe é predominante na definição do substrato energético a ser oxidado e na determinação do nível de movimentação, enquanto que o CLA é predominante na modulação do metabolismo de glicose.

\section{Fígado}

A suplementação da dieta com CLA por si só aumenta a $\beta$-oxidação, a atividade e expressão de proteínas desacopladoras (UCP2). A suplementação com óleo de peixe sozinho ou em conjunto com CLA tem tendência a induzir esse último efeito (porém não significativo), além de estimular fortemente um aumento do número de mitocôndrias e a $\beta$-oxidação. Neste órgão, o CLA induz a produção de EROs em reações de oxido-redução do ciclo de Krebs, como já descrito por nós anteriormente, consequentemente consumindo GSH e elevando a oxidação celular. A suplementação com CLA em conjunto com óleo de peixe tem tendência a aumentar a expressão de UCP2 e a atividade de proteínas desacopladoras (porém não significativo), além de aumentar a $\beta$-oxidação e o número de mitocôndrias. Esses resultados indicam efeitos somatórios no fígado pela suplementação com CLA e óleo de peixe, exceto pela elevada produção de EROs induzida por CLA, a qual é revertida pelo óleo de peixe.

\section{Músculo Sóleo}

A suplementação com CLA por si só não promove nenhum efeito no metabolismo energético do músculo sóleo. A suplementação com óleo de peixe por sua vez aumenta a biogênese mitocondrial via PGC-1 $\alpha$, e a expressão de UCP2. Esses efeitos são mantidos quando a suplementação com óleo de peixe ocorre em conjunto com CLA. 


\section{Hipocampo}

A suplementação com CLA por si só aumenta a expressão de UCP5 e a atividade de proteínas desacopladoras, o que diminui a produção de EROs. O CLA tem tendência a estimular a biogênese mitocondrial, assim como o OP (porém não significativo). A suplementação conjunta de CLA e óleo de peixe mantém a atividade desacopladora e a baixa produção de EROs, além de estimular expressivamente o aumento do número de mitocôndrias. A não detecção do RNAm UCP5 na suplementação conjunta de CLA e óleo de peixe indica que outras UCPs estejam envolvidas nesse processo, além da UCP5. Esses resultados indicam efeitos somatórios no hipocampo pela suplementação com CLA e OP.

\section{Em conjunto}

A suplementação da dieta com CLA aumenta o metabolismo corporal via desacoplamento mitocondrial nos tecidos hepático e cerebral, aumenta a queima de lipídeos corporais através da $\beta$-oxidação hepática e prejudica o metabolismo de glicose.

A suplementação da dieta com óleo de peixe aumenta o metabolismo corporal via desacoplamento mitocondrial em músculo esquelético. Esse efeito é evidente mesmo considerando o menor nível de movimentação dos animais, o que provavelmente está associado a alterações aos níveis de ansiedade induzidas pelo óleo de peixe. Nesse contexto metabólico, o aumento do metabolismo corporal também pode estar associado a elevada biogênese mitocondrial nos tecidos hepático e muscular.

Quando a suplementação da dieta com CLA e óleo de peixe é feita em conjunto, os efeitos do óleo de peixe são predominantes no metabolismo corporal, hepático e muscular e movimentação, e do CLA é a diminuição na sensibilidade à insulina. Já no cérebro, o óleo de peixe potencializa os efeitos do CLA.

De modo geral, concluímos que tanto o óleo de peixe como o CLA podem ser utilizados como boa estratégia alimentar para a prevenção de obesidade e distúrbios metabólicos. 
Referências Bibliagráficas 


\section{REFERÊNCIAS BIBLIOGRÁFICAS}

ALÁN, L.; SMOLKOVÁ, K.; KRONUSOVÁ, E.; ŠANTOROVÁ, J.; JEŽEK, P. Absolute levels of transcripts for mitochondrial uncoupling proteins UCP2, UCP3, UCP4, and UCP5 show different patterns in rat and mice tissues. Journal of Bioenergetics and Biomembranes, v. 41, n. 1, p. $71-78,2009$.

ALBERICI, L. C.; OliVEIRA, H. C. F.; PATRÍCIO, P. R.; KOWALTOWSKI, A. J.; VERCESI, A. E. Hyperlipidemic Mice Present Enhanced Catabolism and Higher Mitochondrial ATP-Sensitive K+ Channel Activity. Gastroenterology, v. 131, n. 4, p. 12281234, 2006.

ALBERTS, B. Biologia molecular da célula. $5^{\text {a }}$ ed. [s.l: s.n.]

ALMEIDA, M. M. De; SOUZA, Y. O. De; DUTRA LUQUETTI, S. C. P.; SABARENSE, C. M.; AMARAL CORRÊA, J. O. do; CONCEIÇÃ̃, E. P. S. da; LISBOA, P. C.; MOURA, E. G. De; ANDRADE SOARES, S. M.; MOURA GUALBERTO, A. C.; GAMEIRO, J.; GAMA, M. A. S. da; FERRAZ LOPES, F. C.; GONZÁLEZ GARCIA, R. M. Cis-9, trans-11 and trans10, cis-12 CLA Mixture does not Change Body Composition, Induces Insulin Resistance and Increases Serum HDL Cholesterol Level in Rats. Journal of Oleo Science, v. 64, n. 5, p. 539 $551,2015$.

ANDREA T. DA POIAN, M. A. R. B. C. Energy Conservation in Metabolism: The Mechanisms of ATP Synthesis. In: Integrative Human Biochemistry: A Textbook for Medical Biochemistry. 1a. ed. New York: Springer New York, 2015. p. 185-221.

ARCH, J. R. S.; HISLOP, D.; WANG, S. J. Y.; SPEAKMAN, J. R. Some mathematical and technical issues in the measurement and interpretation of open-circuit indirect calorimetry in small animals. International Journal of Obesity, v. 30, n. 9, p. 1322-1331, 2006.

ARECHAGA, I.; LEDESMA, A.; RIAL, E. The Mitochondrial Uncoupling Protein UCP1: A Gated Pore. IUBMB Life (International Union of Biochemistry and Molecular Biology: Life), v. 52, n. 3-5, p. 165-173, 2001.

ARMSTRONG, M. B.; TOWLE, H. C. Polyunsaturated fatty acids stimulate hepatic UCP-2 expression via a PPARalpha-mediated pathway. American journal of physiology. Endocrinology and metabolism, v. 281, n. 6, p. E1197-204, 2001.

AUBERT, J.; CHAMPIGNY, O.; SAINT-MARC, P.; NEGREL, R.; COLLINS, S.; RICQUIER, D.; AILHAUD, G. Up-regulation of UCP-2 gene expression by PPAR agonists in preadipose and adipose cells. Biochemical and biophysical research communications, $\mathrm{v}$. 238, n. 2, p. 606-611, 1997.

AYALA, J. E.; SAMUEL, V. T.; MORTON, G. J.; OBICI, S.; CRONIGER, C. M.; SHULMAN, G. I.; WASSERMAN, D. H.; MCGUINNESS, O. P. Standard operating procedures for describing and performing metabolic tests of glucose homeostasis in mice. Disease Models \& Mechanisms, v. 3, n. 9-10, p. 525-534, 2010.

AYDIN, R. Conjugated Linoleic Acid : Chemical Structure, Sources and Biological Properties. Turkish Journal of Veterinary and Animal Science, v. 29, p. 189-195, 2005.

AZAIN, M. J.; HAUSMAN, D. B.; SISK, M. B.; FLATT, W. P.; JEWELL, D. E. Dietary 
conjugated linoleic acid reduces rat adipose tissue cell size rather than cell number. The Journal of nutrition, v. 130, n. 1, p. 1548-1554, 2000.

BAILLIE, R. A.; TAKADA, R.; NAKAMURA, M.; CLARKE, S. D. Coordinate induction of peroxisomal acyl-CoA oxidase and UCP-3 by dietary fish oil: A mechanism for decreased body fat deposition. In: Prostaglandins Leukotrienes and Essential Fatty Acids, 5-6, Anais...1999.

BALABAN, R. S.; NEMOTO, S.; FINKEL, T. Mitochondria, oxidants, and agingCell, 2005.

BANG, H. O.; DYERBERG, J.; HJOORNE, N. The composition of food consumed by Greenland Eskimos. Acta Med Scand, v. 200, n. 1-2, p. 69-73, 1976.

BARALDI, F.; DALALIO, F.; TEODORO, B.; PRADO, I.; CURTI, C.; ALBERICI, L. Body energy metabolism and oxidative stress in mice supplemented with conjugated linoleic acid (CLA) associated to oleic acid. Free radical biology \& medicine, v. 75 Suppl 1, p. S21, 2014.

BARALDI, F. G.; VICENTINI, T. M.; TEODORO, B. G.; DALALIO, F. M.; DECHANDT, C. R. P.; PRADO, I. M. R.; CURTI, C.; CARDOSO, F. C.; UYEMURA, S. a.; ALBERICI, L. C. The combination of conjugated linoleic acid (CLA) and extra virgin olive oil increases mitochondrial and body metabolism and prevents CLA-associated insulin resistance and liver hypertrophy in C57Bl/6 mice. The Journal of Nutritional Biochemistry, v. 28, p. 147-154, 2016.

BARBOSA, K. B. F.; COSTA, N. M. B.; DE CÁSSIA GONÇALVES ALFENAS, R.; DE PAULA, S. O.; MINIM, V. P. R.; BRESSAN, J. Estresse oxidativo: Conceito, implicações e fatores modulatórios. Revista de Nutricao, v. 23, n. 4, p. 629-643, 2010.

BELZUNG, F.; RACLOT, T.; GROSCOLAS, R. Fish oil n-3 fatty acids selectively limit the hypertrophy of abdominal fat depots in growing rats fed high-fat diets. The American journal of physiology, v. 264, n. 6 Pt 2, p. R1111-8, 1993.

BENANI, a; BARQUISSAU, V.; CARNEIRO, L.; SALIN, B.; COLOMBANI, a L.; LELOUP, C.; CASTEILLA, L.; RIGOULET, M.; PENICAUD, L. Method for functional study of mitochondria in rat hypothalamus. J Neurosci Methods, v. 178, n. 2, p. 301-307, 2009.

BENJAMIN DREW ROCKETTA, M. H. and S. R. S. High dose of an n-3 polyunsaturated fatty acid diet lowers activity of C57BL/6 mice. Prostaglandins Leukot Essent Fatty Acids, v. 86, n. 3, p. 137-145, 2012.

BIANCO, A. C. Hormônios tireóideos, UCPs e termogênese. Arquivos Brasileiros de Endocrinologia \& Metabologia, v. 44, n. 4, 2000.

BOSCHINI, R. P.; GARCIA, J. R. Regulação da expressão gênica das UCP2 e UCP3 pela restrição energética, jejum e exercício físico. Revista de Nutricao, v. 18, n. 6, p. 753-764, 2005 .

BRADFORD, M. M. A rapid and sensitive method for the quantitation of microgram quantities of protein utilizing the principle of protein-dye binding. Analytical biochemistry, v. 72, p. 248-254, 1976.

BROWN, M.; EVANS, M.; MCINTOSH, M. Linoleic acid partially restores the triglyceride content of conjugated linoleic acid-treated cultures of 3T3-L1 preadipocytes. Journal of 
Nutritional Biochemistry, v. 12, n. 7, p. 381-387, 2001.

BUSIELLO, R. a.; SAVARESE, S.; LOMBARDI, A. Mitochondrial uncoupling proteins and energy metabolism. Frontiers in Physiology, v. 6, n. 36, p. 1-7, 2015.

CARMO, M. C. N. S.; CORREIA, M. I. T. D. A Importância dos Ácidos Graxos Ômega-3 no Câncer. Revista Brasileira de Cancerologia, v. 55, n. 3, p. 279-287, 2009.

CARNEIRO, S.; CAMPOS, D.; VOURAKIS, L.; CRISTINA, V.; SOARES, G. Influência da Suplementação com Ácidos Graxos n-3 no Desenvolvimento do Estresse Oxidativo em Camundongos. UNOPAR Cient Ciênc Biol Saúde, v. 13, n. 4, p. 251-256, 2011.

CHALON， S.; DELION-VANCASSEL， S.; BELZUNG， C.; GUILLOTEAU， D.; LEGUISQUET, a M.; BESNARD, J. C.; DURAND, G. Dietary fish oil affects monoaminergic neurotransmission and behavior in rats. The Journal of nutrition, v. 128, n. 12, p. 2512-2519, 1998.

CHAN, D. C. Fusion and Fission: Interlinked Processes Critical for Mitochondrial Health. Annual Review of Genetics, v. 46, n. 1, p. 265-287, 2011.

CHEN, H. Disruption of Fusion Results in Mitochondrial Heterogeneity and Dysfunction. Journal of Biological Chemistry, v. 280, n. 28, p. 26185-26192, 2005.

CHEN, Q.; VAZQUEZ, E. J.; MOGHADDAS, S.; HOPPEL, C. L.; LESNEFSKY, E. J. Production of reactive oxygen species by mitochondria: central role of complex III. The Journal of biological chemistry, v. 278, n. 38, p. 36027-31, 2003.

CIVITARESE, A. E.; CARLING, S.; HEILBRONN, L. K.; HULVER, M. H.; UKROPCOVA, B.; DEUTSCH, W. A.; SMITH, S. R.; RAVUSSIN, E. Calorie restriction increases muscle mitochondrial biogenesis in healthy humans. PLoS Medicine, v. 4, n. 3, p. 485-494, 2007.

CLAPIER, V.; GARNIER, A.; VEKSLEY, V. Transcriptional control of mitochondrial biogenesis: The central role of PGC-1 $\alpha$. Cardiovascular Research, v. 79, n. 2, p. 208-217, 2008 .

CLÉMENT, L.; POIRIER, H.; NIOT, I.; BOCHER, V.; GUERRE-MILLO, M.; KRIEF, S.; STAELS, B.; BESNARD, P. Dietary trans-10,cis-12 conjugated linoleic acid induces hyperinsulinemia and fatty liver in the mouse. Journal of lipid research, v. 43, n. 9, p. 1400 1409, 2002.

DA LUZ, G.; DA SILVA, S.; MARQUES, S.; LUCIANO, T. F.; DE SOUZA, C. T. Suplementação de ácidos graxos poli-insaturados ômega-3 reduz marcadores inflamatórios e melhora a ação da insulina em fígado de camundongos. Revista de Nutricao, v. 25, n. 5, p. 621-629, 2012.

DEMAR, J. C.; MA, K.; BELL, J. M.; IGARASHI, M.; GREENSTEIN, D.; RAPOPORT, S. I. One generation of n-3 polyunsaturated fatty acid deprivation increases depression and aggression test scores in rats. Journal of lipid research, v. 47, n. 1, p. 172-180, 2006.

DEPIERI, T. Z.; PINTO, R. R.; CATARIN, J. K.; DE CARLI, M. C. L.; GARCIA JÚNIOR, J. R. UCP-3: regulation of genic expression on skeletal muscle and possible role on body weight control. Arquivos brasileiros de endocrinologia e metabologia, v. 48, n. 3, p. 337-344, 2004.

DYERBERG, J.; BANG, H. O.; HJORNE, N. Fatty acid composition of the plasma lipids in 
Greenland Eskimos. The American journal of clinical nutrition, v. 28, n. 9, p. 958-66, 1975.

EALEY, K. N.; EL-SOHEMY, a; ARCHER, M. C. Effects of dietary conjugated linoleic acid on the expression of uncoupling proteins in mice and rats. Lipids, v. 37, n. 9, p. 853-861, 2002.

ECHTAY, K. S.; ROUSSEL, D.; ST-PIERRE, J.; JEKABSONS, M. B.; CADENAS, S.; STUART, J. a; HARPER, J. a; ROEBUCK, S. J.; MORRISON, A.; PICKERING, S.; CLAPHAM, J. C.; BRAND, M. D. Superoxide activates mitochondrial uncoupling proteins. Nature, v. 415, n. 6867, p. 96-9, 2002.

ESPOSTI, D.D.; HAMELIN,J.; BOSSELUT, N.; SAFFROY, R.; SEBAGH, M.; POMMIER, A.; MARTEL, C.; LEMOINE, A. Mitochondrial roles and cytoprotection in chronic liver injury. Biochemistry Research International, v. 2012, p. 1-16, 2012.

ESTEVES, T. C.; ECHTAY, K. S.; JONASSEN, T.; CLARKE, C. F.; BRAND, M. D. Ubiquinone is not required for proton conductance by uncoupling protein 1 in yeast mitochondria. The Biochemical journal, v. 379, n. Pt 2, p. 309-15, 2004.

EVANS, M.; GEIGERMAN, C.; COOK, J.; CURTIS, L.; KUEBLER, B.; MCINTOSH, M. Conjugated linoleic acid suppresses triglyceride accumulation and induces apoptosis in 3T3-L1 preadipocytes. Lipids, v. 35, n. 8, p. 899-910, 2000.

EVEN, P. C.; NADKARNI, N. a. Indirect calorimetry in laboratory mice and rats: principles, practical considerations, interpretation and perspectives. AJP: Regulatory, Integrative and Comparative Physiology, v. 303, n. June 2012, p. R459-R476, 2012.

FANTUZZI, G. Adipose tissue, adipokines, and inflammationJournal of Allergy and Clinical Immunology, 2005. .

FERREIRA, A.L.A.; MATSUBARA, L. . Defesa E Estresse Oxidativo. Medicina, v. 43, n. 1, p. 61-68, 1997.

FIGUEIRA, T. R.; BARROS, M. H.; CAMARGO, A. a; CASTILHO, R. F.; FERREIRA, J. C. B.; KOWALTOWSKI, A. J.; SLUSE, F. E.; SOUZA-PINTO, N. C.; VERCESI, A. E. Mitochondria as a source of reactive oxygen and nitrogen species: from molecular mechanisms to human health. Antioxidants \& redox signaling, v. 18, n. 16, p. 2029-74, 2013.

FLACHS, P.; HORAKOVA, O.; BRAUNER, P.; ROSSMEISL, M.; PECINA, P.; FRANSSEN-VAN HAL, N.; RUZICKOVA, J.; SPONAROVA, J.; DRAHOTA, Z.; VLCEK, C.; KEIJER, J.; HOUSTEK, J.; KOPECKY, J. Polyunsaturated fatty acids of marine origin upregulate mitochondrial biogenesis and induce beta-oxidation in white fat. Diabetologia, v. 48, n. 11, p. 2365-2375, 2005.

FLACHS, P.; ROSSMEISL, M.; BRYHN, M.; KOPECKY, J. Cellular and molecular effects of $n-3$ polyunsaturated fatty acids on adipose tissue biology and metabolism. Clinical science (London, England : 1979), v. 116, n. 1, p. 1-16, 2009.

FLINTOFF-DYE, N. L.; OMAYE, S. T. Antioxidant effects of conjugated linoleic acid isomers in isolated human low-density lipoproteins. Nutrition Research, v. 25, n. 1, p. 1-12, 2005.

FREY, T. G.; RENKEN, C. W.; PERKINS, G. a. Insight into mitochondrial structure and function from electron tomography. Biochimica et Biophysica Acta - Bioenergetics, v. 1555, n. 1-3, p. 196-203, 2002. 
GARLID, K. D. J. M. J. P. V. M. How do uncoupling proteins uncouple? Biochimica et Biophysica Acta, v. 1459, p. 383-389, 2000.

GARLID, K. D.; JABUREK, M.; JEZEK, P. Mechanism of uncoupling protein action. Biochemical Society transactions, v. 29, n. Pt 6, p. 803-806, 2001.

GARLID, K. D.; OROSZ, D. E.; MODRIANSKÝ, M.; VASSANELLI, S.; JEZEK, P. On the mechanism of fatty acid-induced proton transport by mitochondrial uncoupling protein. The Journal of biological chemistry, v. 271, n. 5, p. 2615-2620, 1996.

GEORGE, E.; PALADE, M. D. An Electron Microscope Study of the Mitochondrial Structure. J Histochem Cytochem, v. 1, n. 4, p. 188-211, 1953.

GNAIGER, E. Mitochondrial respiratory control. In: Mitochondr. Physiol. Soc. electronic ed: www.mitophysiology.org. [s.l: s.n.]

GNAIGER, E. Mitochondrial pathways and respiratory control an introduction to oxphos analysis. [s.l: s.n.]

GUO, W.; XIE, W.; LEI, T.; HAMILTON, J. a. Eicosapentaenoic acid, but not oleic acid, stimulates beta-oxidation in adipocytes. Lipids, v. 40, n. 8, p. 815-821, 2005.

GURNELL, M. PPAR Gamma and Metabolism : Insights From the Study of Human Genetic Variants. Clin Endocrinol, v. 59, n. 3, p. 1-10, 2003.

HALADE, G. V.; RAHMAN, M. M.; FERNANDES, G. Effect of CLA isomers and their mixture on aging C57Bl/6J mice. European Journal of Nutrition, v. 48, n. 7, p. 409-418, 2009.

HINKLE, P. C. P/O ratios of mitochondrial oxidative phosphorylation. Biochimica et Biophysica Acta - Bioenergetics, v. 1706, n. 1-2, p. 1-11, 2005.

HIRABARA, S. M.; FOLADOR, A.; FIAMONCINI, J.; LAMBERTUCCI, R. H.; RODRIGUES, C. F.; ROCHA, M. S.; AIKAWA, J.; YAMAZAKI, R. K.; MARTINS, A. R.; RODRIGUES, A. C.; CARPINELLI, A. R.; PITHON-CURI, T. C.; FERNANDES, L. C.; GORJÃO, R.; CURI, R. Fish oil supplementation for two generations increases insulin sensitivity in rats. Journal of Nutritional Biochemistry, v. 24, n. 6, p. 1136-1145, 2013.

HOCK, M. B.; KRALLI, A. Transcriptional Control of Mitochondrial Biogenesis and Function. Annual Review of Physiology, v. 71, n. 1, p. 177-203, 2009.

HULL, M. a. Omega-3 polyunsaturated fatty acids. Best Practice \& Research Clinical Gastroenterology, v. 25, n. 4-5, p. 547-554, 2011.

IDE, T. Interaction of fish oil and conjugated linoleic acid in affecting hepatic activity of lipogenic enzymes and gene expression in liver and adipose tissue. Diabetes, v. 54, n. February, p. 412-423, 2005.

INSTITUTO BRASILEIRO DE GEOGRAFIA E ESTATÍSTICA - IBGE. Pesquisa nacional de saúde 2013 ciclos de vida brasil e grandes regiões. [s.l: s.n.]

IWASE, Y.; KAMEI, N.; TAKEDA-MORISHITA, M. Antidiabetic Effects of Omega-3 Polyunsaturated Fatty Acids : From Mechanism to Therapeutic Possibilities. Pharmacology \& Pharmacy, v. 6, n. March, p. 190-200, 2015. 
JING LUO, SALWA W. RIZKALLA, JOSETTE BOILLOT, CATHERINE ALAMOWITCH, HASSAN CHAIB, FRANÇOISE BRUZZO, NELLY DESPLAQUE, ANNE-MARIE DALIX, GEORGES DURAND, G. S. Biochemical and Molecular Roles of Nutrients Dietary ( n-3 ) Polyunsaturated Fatty Acids Improve Adipocyte Insulin Action and Glucose Metabolism in Insulin-Resistant Rats : Relation t ... Biochemical and Molecular Roles of Nutrients Dietary ( n-3 ) Polyun. J. Nutr., v. 126, n. November, p. 1951-1958, 1996.

JUMP, D. B., TRIPATHY, S.; DEPNER, C. M. Fatty Acid-Regulated Transcription Factors in the Liver. Annu Rev Nutr, v. 33, n. 6, p. 249-269, 2013.

KARP, G. Cell and molecular biology concepts and experiments. [s.l: s.n.]

KELLY, D. P.; SCARPULLA, R. C. Transcriptional regulatory circuits controlling mitochondrial biogenesis and function. Genes \& Development, n. 314, p. 357-368, 2004.

KELLY, T.; YANG, W.; CHEN, C.-S.; REYNOLDS, K.; HE, J. Global burden of obesity in 2005 and projections to 2030. International journal of obesity (2005), v. 32, n. 9, p. 1431-7, 2008 .

KIM, M.; GOTO, T.; YU, R.; UCHIDA, K.; TOMINAGA, M.; KANO, Y.; TAKAHASHI, N.; KAWADA, T. Fish oil intake induces UCP1 upregulation in brown and white adipose tissue via the sympathetic nervous system. Scientific Reports, v. 5, n. April, p. 18013, 2015.

KIM, Y.; PARK, Y. Conjugated linoleic acid (CLA) stimulates mitochondrial biogenesis signaling by the upregulation of PPAR $\gamma$ coactivator $1 \alpha(\mathrm{PGC}-1 \alpha)$ in $\mathrm{C} 2 \mathrm{C} 12$ cells. Lipids, v. 50, n. 4, p. 329-338, 2015.

KIM-HAN, J. S.; REICHERT, S. a; QUICK, K. L.; DUGAN, L. L. BMCP1: a mitochondrial uncoupling protein in neurons which regulates mitochondrial function and oxidant production. Journal of neurochemistry, v. 79, n. 3, p. 658-68, 2001.

KOBA, K.; AKAHOSHI, A.; YAMASAKI, M.; TANAKA, K.; YAMADA, K.; IWATA, T.; KAMEGAI, T.; TSUTSUMI, K.; SUGANO, M. Dietary conjugated linolenic acid in relation to CLA differently modifies body fat mass and serum and liver lipid levels in rats. Lipids, v. 37, n. 4, p. 343-350, 2002.

KRAUSS, S.; ZHANG, C.-Y.; LOWELL, B. B. The mitochondrial uncoupling-protein homologues. Nature Reviews Molecular Cell Biology, v. 6, n. 3, p. 248-261, mar. 2005.

KUZNETSOV, a V; LASSNIG, B.; GNAIGER, E. Laboratory Protocol Citrate Synthase Mitochondrial Marker Enzyme. Mitochondrial Physiology Network, v. 04, n. 03, p. 1-10, 2010.

L.M., B. N-3 Polyunsaturated Fatty Acids, Inflammation and Obesity-Related Disease. Proceedings of the Nutrition Society, v. 62, n. 2, p. 447-453, 2003.

LAKE, J. A. Eukaryotic origins. Philosophical transactions of the Royal Society of London. Series B, Biological sciences, v. 370, n. 1678, p. 20140321, 2015.

LANZA, I. R.; BLACHNIO-ZABIELSKA, A.; JOHNSON, M. L.; SCHIMKE, J. M.; JAKAITIS, D. R.; LEBRASSEUR, N. K.; JENSEN, M. D.; SREEKUMARAN NAIR, K.; ZABIELSKI, P. Influence of fish oil on skeletal muscle mitochondrial energetics and lipid metabolites during high-fat diet. American journal of physiology. Endocrinology and 
metabolism, v. 304, n. 12, p. E1391-403, 2013.

LEHNEN, T. E.; DA SILVA, M. R.; CAMACHO, A.; MARCADENTI, A.; LEHNEN, A. M. A review on effects of conjugated linoleic fatty acid (CLA) upon body composition and energetic metabolism. Journal of the International Society of Sports Nutrition, v. 12, p. 36, 2015.

LENAZ, G.; GENOVA, M. L. Structural and functional organization of the mitochondrial respiratory chain: a dynamic super-assembly. The international journal of biochemistry \& cell biology, v. 41, n. 10, p. 1750-1772, 2009.

LIANG, H.; WARD, W. F. PGC-1alpha: a key regulator of energy metabolism. Advances in physiology education, v. 30, n. 4, p. 145-51, 2006.

LIFE TECHNOLOGIES. TRIzol ® Reagent. n. 15596026, p. 18-21, 2012.

LIN, P.-Y.; HUANG, S.-Y.; SU, K.-P. A meta-analytic review of polyunsaturated fatty acid compositions in patients with depression. Biological psychiatry, v. 68, n. 2, p. 140-147, 2010.

LIONETTI, L.; MOLLICA, M. P.; DONIZZETTI, I.; GIFUNI, G.; SICA, R.; PIGNALOSA, A.; CAVALIERE, G.; GAITA, M.; DE FILIPPO, C.; ZORZANO, A.; PUTTI, R. High-lard and high-fish-oil diets differ in their effects on function and dynamic behaviour of rat hepatic mitochondria. PLoS ONE, v. 9, n. 3, 2014.

LIONETTI, L.; SICA, R.; MOLLICA, M. P.; PUTTI, R. High-Lard and High-Fish Oil Diets Differ in Their Effects on Insulin Resistance Development, Mitochondrial Morphology and Dynamic Behaviour in Rat Skeletal Muscle. v. 2013, n. September, p. 105-112, 2013.

LIU, Y.; FISKUM, G.; SCHUBERT, D. Generation of reactive oxygen species by the mitochondrial electron transport chain. J Neurochem, v. 80, n. 5, p. 780-787, 2002.

LORENTE-CEBRIÁN, S.; BUSTOS, M.; MARTI, A.; MARTINEZ, J. A.; MORENOALIAGA, M. J. Eicosapentaenoic acid stimulates AMP-activated protein kinase and increases visfatin secretion in cultured murine adipocytes. Clinical science (London, England : 1979), v. 117 , n. 6 , p. 243-249, 2009.

LORENTE-CEBRIÁN, S.; COSTA, A. G. V.; NAVAS-CARRETERO, S.; ZABALA, M.; MARTÍNEZ, J. A.; MORENO-ALIAGA, M. J. Role of omega-3 fatty acids in obesity, metabolic syndrome, and cardiovascular diseases: a review of the evidence. Journal of Physiology and Biochemistry, v. 69, n. 3, p. 633-651, 2013.

MADSEN, L.; FRØYLAND, L.; DYRØY, E.; HELLAND, K.; BERGE, R. K. Docosahexaenoic and eicosapentaenoic acids are differently metabolized in rat liver during mitochondria and peroxisome proliferation. Journal of lipid research, v. 39, n. 3, p. 583-93, 1998.

MATAMALA, J. C.; GIANOTTI, M.; PERICAS, J.; QUEVEDO, S.; ROCA, P.; PALOU, A.; GARCIA-PALMER, F. J. Changes induced by fasting and dietetic obesity in thermogenic parameters of rat brown adipose tissue mitochondrial subpopulations. Biochem J, v. 319 ( $\mathrm{Pt}$ 2, p. 529-534, 1996.

MCBRIDE, H. M.; NEUSPIEL, M.; WASIAK, S. Mitochondria: more than just a powerhouse. Current biology : CB, v. 16, n. 14, p. R551-60, 2006. 
MEI, J.; YU, S.; AHRÉN, B. Study on administration of 1,5-anhydro-D-fructose in C57BL/6J mice challenged with high-fat diet. BMC endocrine disorders, v. 10, n. 1, p. 17, 2010.

MITCHELL, P. Coupling of phosphorylation to electron and hydrogen transfer by a chemiosmotic type of mechanism. Nature, v. 191, p. 144-148, 1961.

MOLliCA, M. P.; TRINCHESE, G.; CAVALIERE, G.; DE FILIPPO, C.; COCCA, E.; GAITA, M.; DELLA-GATTA, A.; MARANO, A.; MAZZARELLA, G.; BERGAMO, P. c9,t11-Conjugated linoleic acid ameliorates steatosis by modulating mitochondrial uncoupling and Nrf2 pathway. Journal of lipid research, v. 55, n. 5, p. 837-49, 2014.

MORI, T.; KONDO, H.; HASE, T.; TOKIMITSU, I.; MURASE, T. Dietary fish oil upregulates intestinal lipid metabolism and reduces body weight gain in C57BL/6J mice. The Journal of Nutrition, v. 137, n. 12, p. 2629-2634, 2007.

MORRIS, M. C.; EVANS, D. a; BIENIAS, J. L.; TANGNEY, C. C.; BENNETT, D. a; WILSON, R. S.; AGGARWAL, N.; SCHNEIDER, J. Consumption of fish and n-3 fatty acids and risk of incident Alzheimer disease. Archives of neurology, v. 60, n. 7, p. 940-946, 2003.

MOTAWI, T. M. K.; HASHEM, R. M.; RASHED, L. a; EL-RAZEK, S. M. A. Comparative study between the effect of the peroxisome proliferator activated receptor-alpha ligands fenofibrate and n-3 polyunsaturated fatty acids on activation of 5'-AMP-activated protein kinase-alpha1 in high-fat fed rats. The Journal of pharmacy and pharmacology, v. 61, n. 10, p. 1339-46, 2009.

MOURÃO, D. M.; MONTEIRO, J. B. R.; COSTA, N. M. B.; STRINGHETA, P. C.; MINIM, V. P. R.; DIAS, C. M. G. C. Ácido Linoléico Conjugado E Perda De Peso. Revista de Nutricao, v. 18, n. 3, p. 391-399, 2005.

MURPHY, M. P. How mitochondria produce reactive oxygen species. The Biochemical journal, v. 417, n. 1, p. 1-13, 2009.

NADEGE, B., PATRICK, L., ROSSIGNOL, R. Mitochondria: from bioenergetics to the metabolic regulation of carcinogenesis. Frontiers in Bioscience, n. 14, p. 4015-4034, 2009.

NAKATANI, T.; TSUBOYAMA-KASAOKA, N.; TAKAHASHI, M.; MIURA, S.; EZAKI, $O$. Mechanism for peroxisome proliferator-activated receptor- $\alpha$ activator induced up-regulation of UCP2 mRNA in rodent hepatocytes. Journal of Biological Chemistry, v. 277, n. 11, p. 9562-9569, 2002.

NELSON, D. L.; COX, M. M. Lehninger: princípios de bioquímica. $6^{\mathrm{a}}$. ed. Porto Alegre. Editora Artmed. 1336p. 2014.

NESCHEN, S.; MOORE, I.; REGITTNIG, W.; YU, C. L.; WANG, Y.; PYPAERT, M.; PETERSEN, K. F.; SHULMAN, G. I. Contrasting effects of fish oil and safflower oil on hepatic peroxisomal and tissue lipid content. Am J Physiol Endocrinol Metab, v. 282, n. 2, p. E395E401, 2002.

NETO, B. G.; TAMBASCIA, M. a. Avaliação laboratorial e diagnóstico da resistencia insulínica. Atherosclerosis, v. 13, n. 2, p. 42-49, 2006.

NICHOLLS, D. G. A history of UCP1. Biochemical Society transactions, v. 29, n. Pt 6, p. 751-755, 2001. 
NICOLSON, G. L. Metabolic syndrome and mitochondrial function: Molecular replacement and antioxidant supplements to prevent membrane peroxidation and restore mitochondrial function. Journal of Cellular Biochemistry, v. 100, n. 6, p. 1352-1369, 2007.

NISOLI, E.; CLEMENTI, E.; CARRUBA, M. O.; MONCADA, S. Defective Mitochondrial Biogenesis: A Hallmark of the High Cardiovascular Risk in the Metabolic Syndrome? Circulation Research, v. 100, n. 6, p. 795-806, 2007.

NOVELLO, D.; FRANCESCHINI, P.; QUINTILIANO, D. A. A importância dos ácidos graxos w-3 e w-6 para a prevençao de doenças e na saúde humana. Revista Salus-Guarapuava, v. 2, n. 1, p. 77-87, 2008.

NUNES, M. A.; APPOLINARIO, J. C.; GALVÃO, A. L.; COLABORADORES, W. C. e. Transtornos alimentares e obesidade. $2^{\mathrm{a}}$. ed. Porto Alegre: Artmed, 2006.

OH, D. Y.; TALUKDAR, S.; BAE, E. J.; IMAMURA, T.; MORINAGA, H.; FAN, W.; LI, P.; LU, W. J.; WATKINS, S. M.; OLEFSKY, J. M. GPR120 Is an Omega-3 Fatty Acid Receptor Mediating Potent Anti-inflammatory and Insulin-Sensitizing Effects. Cell, v. 142, n. 5, p. $687-$ 698, 2010.

OH, D. Y.; WALENTA, E.; AKIYAMA, T. E.; LAGAKOS, W. S.; LACKEY, D.; PESSENTHEINER, A. R.; SASIK, R.; HAH, N.; CHI, T. J.; COX, J. M.; POWELS, M. A.; DI SALVO, J.; SINZ, C.; WATKINS, S. M.; ARMANDO, A. M.; CHUNG, H.; EVANS, R. M.; QUEHENBERGER, O.; MCNELIS, J.; BOGNER-STRAUSS, J. G.; OLEFSKY, J. M. A Gpr120-selective agonist improves insulin resistance and chronic inflammation in obese mice. Nature medicine, v. 20, n. 8, p. 942-7, 2014.

OHNUKI, K.; HARAMIZU, S.; OKI, K.; ISHIHARA, K.; FUSHIKI, T. A single oral administration of conjugated linoleic acid enhanced energy metabolism in mice. Lipids, v. 36, n. 6 , p. 583-587, 2001.

OLESZCZUK，J.; OLESZCZUK，L.; SIWICKI， a. K.; SKOPIŃSKA-RÓŻEWSKA，E. Biological effects of conjugated linoleic acids supplementation. Polish Journal of Veterinary Sciences, v. 15, n. 2, p. 403-408, 2012.

OLIVEIRA, L. H.; ALMEIDA, P. De. Obesidade : Aspectos Gerais Dos Fatores, Tratamento E Prevenção. Revista Polidisciplinar Eletrônica da Faculdade Guairacá, v. 04, n. 2011, p. 34-44, 2012.

PARDO-ANDREU, G. L.; NUÑEZ-FIGUEREDO, Y.; TUDELLA, V. G.; CUESTA-RUBIO, O.; RODRIGUES, F. P.; PESTANA, C. R.; UYEMURA, S. A.; LEOPOLDINO, A. M.; ALBERICI, L. C.; CURTI, C. The anti-cancer agent nemorosone is a new potent protonophoric mitochondrial uncoupler. Mitochondrion, v. 11, n. 2, p. 255-263, 2011.

PARIZA, M. W. Perspective on the safety and effectiveness of conjugated linoleic acid. American Journal of Clinical Nutrition, v. 79, n. 6, p. 1132S-1136S, 2004.

PARK, Y.; PARIZA, M. W. Mechanisms of body fat modulation by conjugated linoleic acid (CLA). Food Research International, v. 40, n. 3, p. 311-323, 2007.

PEREIRA, A. F.; SÁ, L. L.; REIS, F. H. Z.; CARDOSO, F. C.; ALBERICI, R. M.; PRADO, I. M. R.; EBERLIN, M. N.; UYEMURA, S. a; CURTI, C.; ALBERICI, L. C. Administration of a murine diet supplemented with conjugated linoleic acid increases the expression and activity 
of hepatic uncoupling proteins. Journal of bioenergetics and biomembranes, v. 44, n. 5, p. 587-96, 2012.

PEREIRA, L. O.; FRANCISCHI, R. P. De; LANCHA JR., A. H. Obesidade: hábitos nutricionais, sedentarismo e resistência à insulina. Arquivos Brasileiros de Endocrinologia \& Metabologia, v. 47, n. 2, p. 111-127, 2003.

PEREIRA, T. F. C. Obesidade: A epidemia do Século XXI? [s.1: s.n.].

PHILP, L. K.; HEILBRONN, L. K.; JANOVSKA, A.; WITTERT, G. A. Dietary enrichment with fish oil prevents high fat-induced metabolic dysfunction in skeletal muscle in mice. PLoS ONE, v. 10, n. 2, p. 1-19, 2015.

PUIGSERVER, P.; RHEE, J.; LIN, J.; WU, Z.; YOON, J. C.; ZHANG, C. Y.; KRAUSS, S.; MOOTHA, V. K.; LOWELL, B. B.; SPIEGELMAN, B. M. Cytokine Stimulation of Energy Expenditure through p38 MAP Kinase Activation of PPAR $\gamma$ Coactivator-1. Molecular Cell, v. 8, n. 5, p. 971-982, 2001.

PUIGSERVER, P.; SPIEGELMAN, B. M. Peroxisome proliferator-activated receptor coactivator $1 \alpha$ (PGC-1 $\alpha)$ : Transcriptional coactivator and metabolic regulator. Endocrine Reviews, v. 24, n. 1, p. 78-90, 2003.

PUIGSERVER, P.; WU, Z.; PARK, C. W.; GRAVES, R.; WRIGHT, M.; SPIEGELMAN, B. M. A cold-inducible coactivator of nuclear receptors linked to adaptive thermogenesis. Cell, v. 92, n. 6, p. 829-839, 1998.

PUTTI, R.; SICA, R.; MIGLIACCIO, V.; LIONETTI, L. Diet impact on mitochondrial bioenergetics and dynamics. Frontiers in Physiology, v. 6, n. April, p. 1-7, 2015.

RAHMAN, M. M.; HALADE, G. V.; EL JAMALI, A.; FERNANDES, G. Conjugated linoleic acid (CLA) prevents age-associated skeletal muscle loss. Biochemical and Biophysical Research Communications, v. 383, n. 4, p. 513-518, 2009.

RAHMAN, S. M.; WANG, Y.; YOTSUMOTO, H.; CHA, J.; HAN, S.; INOUE, S.; YANAGITA, T. Effects of conjugated linoleic acid on serum leptin concentration, body-fat accumulation, and beta-oxidation of fatty acid in OLETF rats. Nutrition (Burbank, Los Angeles County, Calif.), v. 17, n. 00, p. 385-390, 2001.

RAMSDEN, D. B.; HO, P. W.-L.; HO, J. W.-M.; LIU, H.-F.; SO, D. H.-F.; TSE, H.-M.; CHAN, K.-H.; HO, S.-L. Human neuronal uncoupling proteins 4 and 5 (UCP4 and UCP5): structural properties, regulation, and physiological role in protection against oxidative stress and mitochondrial dysfunction. Brain and behavior, v. 2, n. 4, p. 468-78, 2012.

RE, S.; ZANOLETTI, M.; EMANUELE, E. Aggressive dogs are characterized by low omega3 polyunsaturated fatty acid status. Veterinary Research Communications, v. 32, n. 3, p. 225$230,2008$.

RIBEIRO, S.M.R.; QUEIROZ, J.H.; PELUZO, M.C.G.; COSTA, N.M.B.; MATTA, S.L.P.; QUEIROZ, M. E. L. R. A formacão e os efeitos das espécies reativas de oxigênio no meio biológico. Bioscience Journal, v. 21, n. 3, p. 133-149, 2005.

RICHTER, Y.; HERZOG, Y.; COHEN, T.; STEINHART, Y. The effect of phosphatidylserinecontaining omega-3 fatty acids on memory abilities in subjects with subjective memory 
complaints: a pilot study. Clinical interventions in aging, v. 5, p. 313-316, 2010.

RISÉRUS, U.; BASU, S.; JOVINGE, S.; FREDRIKSON, G. N.; ÄRNLÖV, J.; VESSBY, B. Supplementation with conjugated linoleic acid causes isomer-dependent oxidative stress and elevated C-reactive protein: A potential link to fatty acid-induced insulin resistance. Circulation, v. 106, n. 15, p. 1925-1929, 2002.

ROHRBACH, S. Effects of dietary polyunsaturated fatty acids on mitochondria. Current pharmaceutical design, v. 15, n. 2, p. 4103-4116, 2009.

ROUSSET, S.; ALVES-GUERRA, M.-C.; MOZO, J.; MIROUX, B.; CASSARD-DOULCIER, A.-M.; BOUILLAUD, F.; RICQUIER, D. The biology of mitochondrial uncoupling proteins. Diabetes, v. 53 Suppl 1, n. February, p. S130-S135, 2004.

RYDER, J. W.; PORTOCARRERO, C. P.; SONG, X. M.; CUI, L.; YU, M.; COMBATSIARIS, T.; GALUSKA, D.; BAUMAN, D. E.; BARBANO, D. M.; CHARRON, M. J.; ZIERATH, J. R.; HOUSEKNECHT, K. L. Isomer-specific antidiabetic properties of conjugated linoleic acid: Improved glucose tolerance, skeletal muscle insulin action, and UCP-2 gene expression. Diabetes, v. 50, n. 5, p. 1149-1157, 2001.

SALTIEL, A. R. Fishing Out a Sensor for Anti-inflammatory Oils. Cell, v. 142, n. 5, p. 672$674,2010$.

SALVADOR, M. de J. R. Influência de grupos amínicos na actividade dos complexos respiratórios mitocondriais. 2003. Universidade de Coimbra, 2003.

SANCHIS, D.; FLEURY, C.; GOUBERN, M.; HUANG, Q.; NEVEROVA, M.; GRÉGOIRE, F.; RAIMBAULT, S.; MIROUX, B.; COLLINS, S.; SELDIN, M.; RICHARD, D.; WARDEN, C.; BOUILLAUD, F.; RICQUIER, D.; CHOMIKI, N.; GRE, F.; EASLICK, J.; LE, C. BMCP1, a Novel Mitochondrial Carrier with High Expression in the Central Nervous System of Humans and Rodents , and Respiration Uncoupling Activity in Recombinant Yeast BMCP1 , a Novel Mitochondrial Carrier with High Express. Biochemistry, v. 273, n. 51, p. 34611-34615, 1998.

SANTOS-ZAGO, L. F.; BOTELHO, A. P.; DE OLIVEIRA, A. C. Os efeitos do ácido linoléico conjugado no metabolismo animal: Avanço das pesquisas e perspectivas para o futuro. Revista de Nutricao, v. 21, n. 2, p. 195-221, 2008.

SAPRA, R.; BAGRAMYAN, K.; ADAMS, M. W. W. A simple energy-conserving system: proton reduction coupled to proton translocation. Proceedings of the National Academy of Sciences of the United States of America, v. 100, n. 13, p. 7545-50, 2003.

SARAVANAN, P.; DAVIDSON, N. C.; SCHMIDT, E. B.; CALDER, P. C. Cardiovascular effects of marine omega-3 fatty acids. Lancet, v. 376, n. 9740, p. 540-50, 2010.

SCARPULLA, R. C. Metabolic control of mitochondrial biogenesis through the PGC-1 family regulatory network. Biochim Biohys Acta, v. 1813, n. 7, p. 1269-1278, 2011.

SCHULTZ, B. E.; CHAN, S. I. STructures and Proton-Pumping Strategies of Mitochondrial Respiratory Enzymes. p. 23-65, 2001.

SCHWARTZ, R. M.; DAYHOFF, M. O. Origins of prokaryotes, eukaryotes, mitochondria, and chloroplasts. Science (New York, N.Y.), v. 199, n. 4327, p. 395-403, 1978.

SHABALINA, I.; PETROVIC, N.; DEJONG, J. a.; KALINOVICH, A.; CANNON, B.; 
NEDERGAARD, J. UCP1 in Brite/Beige adipose tissue mitochondria is functionally thermogenic. Cell Reports, v. 5, n. 5, p. 1196-1203, 2013.

SHEARER, G. C.; SAVINOVA, O. V.; HARRIS, W. S. Fish oil - How does it reduce plasma triglycerides? Biochimica et Biophysica Acta - Molecular and Cell Biology of Lipids, v. 1821, n. 5, p. 843-851, 2012.

SNEDDON, A. a.; VERNON RAYNER, D.; MITCHELL, S. E.; BASHIR, S.; HA, J. H.; WAHLE, K. W.; MORRIS, A. C.; WILLIAMS, L. M. Dietary supplementation with conjugated linoleic acid plus n-3 polyunsaturated fatty acid increases food intake and brown adipose tissue in rats. Nutrients, v. 1, n. 2, p. 178-196, 2009.

SPIEGELMAN, B. M.; HEINRICH, R. Biological control through regulated transcriptional coactivators. Cell, v. 119, n. 2, p. 157-167, 2004.

STRYER, L.; BERG, J. M.; TYMOCZKO, J.L. Bioquímica. $7^{\text {a }}$ edição. Editora Guanabara Koogan. 1114p. 2014

SUCHANKOVA, G.; TEKLE, M.; SAHA, A. K.; RUDERMAN, N. B.; CLARKE, S. D.; GETTYS, T. W. Dietary polyunsaturated fatty acids enhance hepatic AMP-activated protein kinase activity in rats. Biochemical and Biophysical Research Communications, v. 326, n. 4, p. 851-858, 2005.

SULLIVAN, P. G.; RIPPY, N. A.; DORENBOS, K.; CONCEPCION, R. C.; AGARWAL, A. K.; RHO, J. M. The Ketogenic Diet Increases Mitochondrial Uncoupling Protein Levels and Activity. Annals of Neurology, v. 55, n. 4, p. 576-580, 2004.

SUN, C.; WEI, Z. W.; LI, Y. DHA regulates lipogenesis and lipolysis genes in mice adipose and liver. Molecular Biology Reports, v. 38, n. 2, p. 731-737, 2011.

SUN, R.; WANG, X.; LIU, Y.; XIA, M. Dietary supplementation with fish oil alters the expression levels of proteins governing mitochondrial dynamics and prevents high-fat dietinduced endothelial dysfunction. The British journal of nutrition, v. 112, n. 2, p. 145-53, 2014.

TAKAHASHI, M.; TSUBOYAMA-KASAOKA, N.; NAKATANI, T.; ISHII, M.; TSUTSUMI, S.; ABURATANI, H.; EZAKI, O. Fish oil feeding alters liver gene expressions to defend against PPARalpha activation and ROS production. American journal of physiology. Gastrointestinal and liver physiology, v. 282, n. 2, p. G338-G348, 2002.

TSUBOYAMA-KASAOKA, N.; TAKAHASHI, M.; KIM, H.; EZAKI, O. Up-regulation of liver uncoupling protein-2 mRNA by either fish oil feeding or fibrate administration in mice. Biochemical and biophysical research communications, v. 257, n. 3, p. 879-885, 1999.

TURRENS, J. F.; ALEXANDRE, A.; LEHNINGER, A. L. Ubisemiquinone is the electron donor for superoxide formation by complex III of heart mitochondria. Archives of Biochemistry and Biophysics, v. 237, n. 2, p. 408-414, 1985.

VALERO, T. Mitochondrial biogenesis: pharmacological approaches. Curr Pharm Des, v. 20, n. 35, p. 5507-5509, 2014.

VAN DER BLIEK, A. M.; SHEN, Q.; KAWAJIRI, S. Mechanisms of mitochondrial fission and fusion. Cold Spring Harbor Perspectives in Biology, v. 5, n. 6, 2013. 
VAUGHAN, R. a; GARCIA-SMITH, R.; BISOFFI, M.; CONN, C. a; TRUJILLO, K. a. Conjugated linoleic acid or omega 3 fatty acids increase mitochondrial biosynthesis and metabolism in skeletal muscle cells. Lipids in Health and Disease, v. 11, n. 1, p. 142, 2012.

VINOT, N.; JOUIN, M.; LHOMME-DUCHADEUIL, A.; GUESNET, P.; ALESSANDRI, J. M.; AUJARD, F.; PIFFERI, F. Omega-3 fatty acids from fish oil lower anxiety, improve cognitive functions and reduce spontaneous locomotor activity in a non-human primate. PLoS ONE, v. 6, n. 6, p. 1-8, 2011.

WARGENT, E.; SENNITT, M. V; STOCKER, C.; MAYES, A. E.; BROWN, L.; O’DOWD, J.; WANG, S.; EINERHAND, A. W. C.; MOHEDE, I.; ARCH, J. R. S.; CAWTHORNE, M. a. Prolonged treatment of genetically obese mice with conjugated linoleic acid improves glucose tolerance and lowers plasma insulin concentration: possible involvement of PPAR activation. Lipids in health and disease, v. 4, p. 3, 2005.

WEINTRAUB, H. S. Overview of Prescription Omega-3 Fatty Acid Products for Hypertriglyceridemia. Postgraduate Medicine, v. 126, n. 7, p. 7-18, 2014.

WELLEN, K. E.; HOTAMISLIGIL, G. S. Obesity-induced inflammatory changes in adipose tissueJournal of Clinical Investigation, 2003. .

WENZ, T. Regulation of mitochondrial biogenesis and PGC-1 $\alpha$ under cellular stress. Mitochondrion, v. 13, n. 2, p. 134-142, 2013.

WEST, D. B.; BLOHM, F. Y.; TRUETT, A. A.; DELANY, J. P. Conjugated Linoleic Acid Persistently Increases Total Energy Expenditure in AKR/J Mice without Increasing Uncoupling Protein Gene Expression. The Journal of Nutrition, v. 130, n. 10, p. 2471-2477, 2000.

WEST, D.; DELANY, J.; CAMET, P.; BLOHM, F.; TRUETT, A.; SCIMECA, J. Effects of conjugated linoleic acid on body fat and energy metabolism in the mouse. The American journal of physiology, v. 275, p. R667-72, 1998.

WESTERMANN, B. Mitochondrial fusion and fission in cell life and death. Nature Reviews Molecular Cell Biology, v. 11, n. 12, p. 872-884, 2010.

WESTERMANN, B. Bioenergetic role of mitochondrial fusion and fission. In: Biochimica et Biophysica Acta - Bioenergetics, 10, Anais...2012.

WHO CONSULTATION ON OBESITY. Obesity: preventing and managing the global epidemic: report of a WHO consultation. p. 253, 2000.

WINER, J.; JUNG, C. K.; SHACKEL, I.; WILLIAMS, P. M. Development and validation of real-time quantitative reverse transcriptase-polymerase chain reaction for monitoring gene expression in cardiac myocytes in vitro. Analytical biochemistry, v. 270, n. 1, p. 41-49, 1999.

WINKLER, E.; KLINGENBERG, M. Effect of fatty acids on $\mathrm{H}+$ transport activity of the reconstituted uncoupling protein. Journal of Biological Chemistry, v. 269, n. 4, p. 2508-2515, 1994.

WU, Z.; PUIGSERVER, P.; ANDERSSON, U.; ZHANG, C.; ADELMANT, G.; MOOTHA, V.; TROY, A.; CINTI, S.; LOWELL, B.; SCARPULLA, R. C.; SPIEGELMAN, B. M. Mechanisms controlling mitochondrial biogenesis and respiration through the thermogenic coactivator PGC-1 $\alpha$. Cell, v. 98, n. 1, p. 115-124, 1999. 
YAMAZAKI, R. K.; SHEN, T.; SCHADE, G. B. A diet rich in (n-3) fatty acids increases peroxisomal $\beta$-oxidation activity and lowers plasma triacylglycerols without inhibiting glutathione-dependent detoxication activities in the rat liver. Biochimica et Biophysica Acta (BBA)/Lipids and Lipid Metabolism, v. 920, n. 1, p. 62-67, 1987.

YU, X. X.; MAO, W.; ZHONG, a; SCHOW, P.; BRUSH, J.; SHERWOOD, S. W.; ADAMS, S. H.; PAN, G. Characterization of novel UCP5/BMCP1 isoforms and differential regulation of UCP4 and UCP5 expression through dietary or temperature manipulation. The FASEB journal : official publication of the Federation of American Societies for Experimental Biology, v. 14, n. 11, p. 1611-1618, 2000.

ZHANG, C.; PERRET, P.; KRAUSS, S.; PERONI, O.; GRUJIC, D.; HAGEN, T.; VIDALPUIG, A. J.; BOSS, O.; KIM, Y.; ZHENG, X. X.; WHEELER, M. B.; SHULMAN, G. I.; CHAN, C. B.; LOWELL, B. B.; HAVEN, N.; ISLAND, P. E.; CA, C. Uncoupling Protein-2 Negatively Regulates Insulin Secretion and Is a Major Link between Obesity , N Cell Dysfunction, and Type 2 Diabetes University of Prince Edward Island. v. 105, p. 745-755, 2001.

ZHOU, M.; DIWU, Z.; PANCHUK-VOLOSHINA, N.; HAUGLAND, R. P. A stable nonfluorescent derivative of resorufin for the fluorometric determination of trace hydrogen peroxide: applications in detecting the activity of phagocyte NADPH oxidase and other oxidases. Analytical biochemistry, v. 253, n. 2, p. 162-168, 1997.

ZHOU, X.-R.; SUN, C.-H.; LIU, J.-R.; ZHAO, D. Dietary conjugated linoleic acid increases PPAR gamma gene expression in adipose tissue of obese rat, and improves insulin resistance. Growth hormone \& IGF research : official journal of the Growth Hormone Research Society and the International IGF Research Society, v. 18, n. 5, p. 361-8, 2008. 